1917

Faust

Studies on the Agamic Trematodes of the Bitter Root Valley, Montana 



\section{STUDIES ON THE AGAMIC TREMATODES OF THE BITTER ROOT VALLEY, MONTANA}

BY

ERNEST CARROLL FAUST

A. B. Oberlin College, 1912.

M. A. University of Illinois, 1914.

\section{THESIS}

Submitted in Partial Fulfillment of the Requirements for the

Degree of

DOCTOR OF PHILOSOPHY

IN ZOOLOGY

IN

THE GRADUATE SCHOOL

OF THE

UNIVERSITY OF ILLINOIS

1917 


\section{Digitized by the Internet Archive in 2013}




\section{U N I V ER S I T Y O F I L L I NOIS \\ THE GRADUATE SCHOOL}

$$
\operatorname{MAY} q_{\text {I9I }^{7}}
$$

I HEREBY RECOMMEND THAT THE THESIS PREPARED UNDER MY SUPERVISION BY ERIEST CARROLL FAUST

ENTITLED STUDIES ON THE ACANIC TREAATODES OF THE BITTER ROOT VALLEY MONTANA

BE ACCEPTED AS FULFILLING THIS PART OF THE REQUIREMENTS FOR THE DEGREE OF. DOCTOR OF PHILOSOPHY

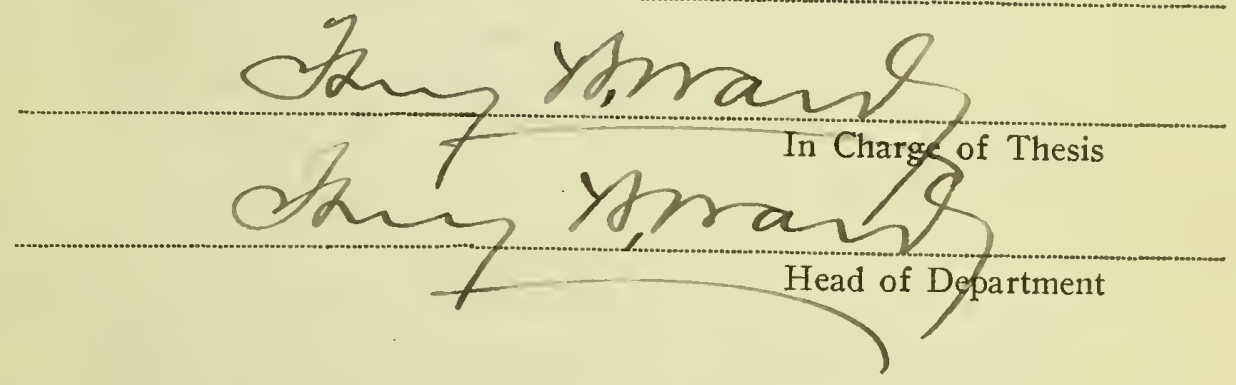

Recommendation concurred in :*

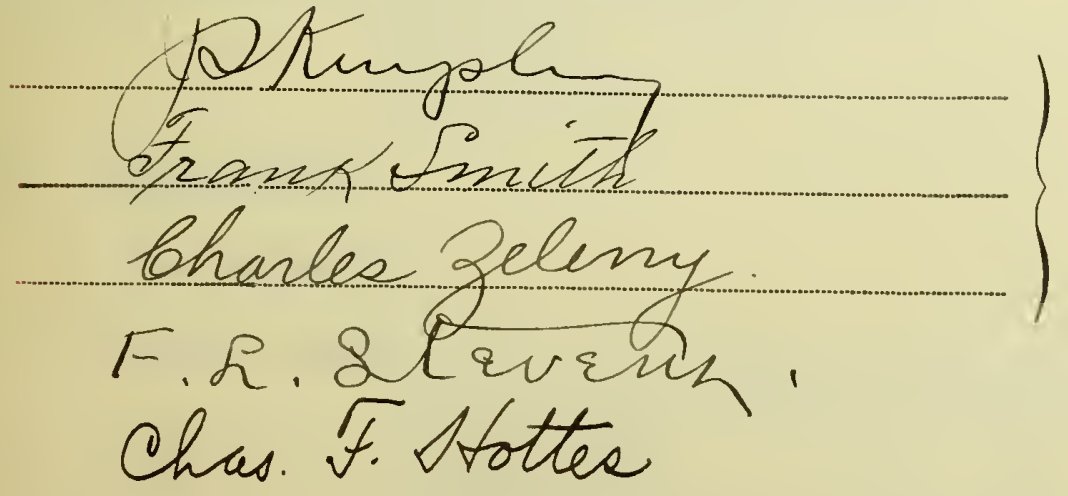

Committee

on

Final Examination*

*Required for doctor's degree but not for master's. 

STUDIES ON THE AGAMIC TREMATODES

OF THE

BITTER ROOT VALLEY MONTANA

I. Introauction.

Suggestion of the problem.

Acknovl edgements.

II. Physiography and Biology of the Bitter Root Valley.

Water-shed and drainage.

Effect of the Ice-sheet.

Average water-fall per mile.

Type of stream determined by above conditions.

Biological isolation of the otream.

Cause.

Period.

Significance.

Snails of the Valley.

Species.

Distribution.

Location of collections (with map).

Relation of the agamic trematode to the snail.

Per cent of infection.

Virulence of infection.

III. Methods of Investigation.

Examination of Living Material.

Methods.

Organs best stuaied in living material.

Examination of Preserved Material.

Fixation Methods.

staining.

sectioning.

IV. Morphology.

Introduction.

Embryology.

Distinction between Parthenitae anà Larvoe.

Development of the Germ-ball.

Conclusions.

Probable history of the Germ Layers and Organs.

Parthenitae.

Characteristic development in Monostomes, Holostomes and Distomes. 

Localization of the Germinal Epithelium. Comparison with lametio Gern Layers.

Cercariae. General.

The Integument.

Theories of its Origin.

Evidence of Origin from the present study.

The Parenchyma.

Kusculature.

Armature.

Glands.

Excretory Systems in Cercariae and Parthenita.

Description of the Systems in Cercariae.

The System in the Parthenitae.

Excretory Granules.

Discussion.

Genitalia.

Description of the Systems in Monostomes, Holostomes, and Distomes.

Digestive System.

Nervous system.

Introduction.

Nervous System in Adult Trematodes.

The Gross System in Cercaria trisolenata.

Stages in Development.

The Details of the Distome Nervous System.

The Monostome Nervous System.

Plementation ana Eye-spots.

The System in Furcocercariae.

The Holostome Type.

The Nerve Complex in Parthenitae.

Ganglion Cells.

Discussion and Sumrary.

V. Description of Species of Agamic Trematodes of the Bitter $\int^{96}$
Root Valley Montana.

Introduction.

Monostomata.

Cercaria peliucida Faust 1917.

Cercaria konaclensis Faust $151 \%$.

Holostomata.

Cercaria flabelliformis Faust 1917.

Comparison with Tetracotyle pipientis nov. spec.

Cercaria ptychocheilus Faust 1917. 

Distomata.

Xiph1diocercariae.

Corcaria crenata Faust 1917.

Cercar1a glandulosa Faust $191 \%$.

Cercar1a diaphana Faust 1917.

Cercaria denaritica Faust $191 \%$.

Cercaria micropharynx Faust 1517.

Echinostome Cercariat.

Cercaria racerosa Faust 1917.

Furcocercariae.

Cercaria trisolenata Faust 1917.

Cercaria biflexa Faust 1917.

Cercaria gracillima Foust 1917.

Cercaria tuberistoma Faust 1917.

VI. Pathology.

VII. Problems Presented.

Interrelation of Trematodes.

Is the Group Polyphyletic?

Lonostome Relationships.

Schis tosomidae.

Definition of the Family.

Holostome Relationships.

Probable Larvae of the Family.

Bearing of Cercariae-Studies on the Problem.

Relation of Trematodes to Other Groups.

Annelid Analogies.

Rotifer and Arthropod Theories.

Turbellarian Relationships.

The Life Cycles of the Trematodes of the Digenetic Groups.

The Gametic Cycle (Hermaphroditic and Dioecious). Laurer's canal.

The Agamic Cycle (Parthenogenetic).

Significance.

Difference in structure betwean Cercariae Germ-balls and

Parthenitae Gerru-balls.

Relation to Rejuvenescence.

Can the Trematode Propagate Indefinitely by Aganic Methods?

The Primitive Cycle of tine Trematode.

Agamic Modiflcations of the Gametic

Typo.

VIII. Surmary.

IX. Iiterature Cited.

X. Explanation of Plates. 

I. Introduction.

During a two-years residence at Missoula Montana from 1914 to 1916 the writer became acquainted with the biology of the intermontana region of the Bitter Root Valley. The heavy trematode infection of animals in this locality has led to the study of the agamic trematodss of the region.

An opportunity is taken at th1s place to express appreciation to all who have alded in the study, but especially to Professor Henry B. Wara, whose kindness and sincere interest have made the work possible.

\section{The Topography of the Bitter Root Valley.}

The Bitter Root Valley occupies a north-south direction, Iying between the main range of the Bitter Root Mountains to the West and the subsidiary spurs of the Rocky Mountains to the East and South. From Hamilton to the outlet of the Valley at the North, a distance of sorne sixty miles, the Valley has a width of about ten miles. This basin is drainea by the Bitter Root River, a stream which is fed by a large number of tributaries up in the mountains, and which unites with the Missoula River to form the Clark's Fork of the Columbia River in the vicinity of Missoula. The River iles nearer the Bitter Roots than the Rocky Mountains. On the West the Bitter Root peaks rise abruptly as craged prominences and severely sculptured precipices. The water comes almost entirely from the snow on the peaks and is conveyed for the most part by short, straight tributaries, set at right angles to the River. In general these laterals resemble sluiceways of an irrigation system. On the East the slope above the basin is graaual, rising terrace above terrace, only suggesting the height of the 

peaks of the Fockles in the distance.

A considerable part of the present valley topography, especially in the River itself, was conditioned by the tongue of the Cordilleran Ice Sheet which blocked the outlet of the Clark's Fork and caused the formation of Lake Missoula, one part of which extended up the Bitter Root Valley and covered the present Valley to a depth of about one thousand feet, a fact determined by the beach lines at 4200 feet elevation at Stevensville. This lake, altho very transient, has brought with it a large amount of alluvium and detritus which has covered the rough granitic basin and has created a sort of a flood plain, thru which the stream has meandered, shifting the plain frequently and giving rise to num erous bayous and abandoned channels. Some of the old channels have been filled with alluvium and mold and have given rise to a top turf resting on ooze. Others have become spring meadows. In the upper reaches of the Valley and in the tributaries from the Western slope the fall of the water is considerable, often reaching three to four hundred feet per mile. The main stream from Hamilton to the confluence, on the other hand, is very gradual in its falt having a drop of only thirty to thirtyfive feet per mile. The amount of the fall, together with the great deluge of water that is poured off the Bitter Root watershed at the time of the spring thaw, causes a torrent to course down the stream at this season, cleaning out the bed dom to the granitic boulders, and appreciably altering the flocd plain. Orainarily, however, the flow in the lower reaches is only about four or five miles per hour in the main stream, and in the backwater is stagnant, teeming with plankton. 

An interesting of the ecological problem of the Bitter Root fauna is its present blological 180lation. Since the by-prourcts of the wines and smelters at Butte and Anaconda were first emptied into the Missoula Fiver in 1865 that River has been increasingly uninhabitable for aquatic life from the source of the contamination to some distance below the confluence with the Bitter Root River. The sloughs and bayous of the River have become fillei with plant and animal life, imbedded in a loose matrix of Chara. Among the macroscopic forms there are three species of molluscs. Ihese snails have been identified by Mr. Bryant Walker of Detroit, Mich1 gan, as Physa gyrina Say, Lymnaea proxima Lea, and Planorois trivolv1s Say. These forms are the hosts of the agamic trematodes of the Valley.

Two facts stand out predominantly in the stuay of these parasites. The one is, the large number of species of agamic trematcoles in the snails within the limited range of the Valiey. The other fact is, the high per cent of infection among inaiviauals of a species, and, coupled with that, the heavy infection within each infected individual.

There have been found ina single season's collection thirteen trematode species in the snails of the Valley, and one larval trematode in the squaw-fish, ptychocheilus oregonensis Richardson. A total of fifteen collections of snails was made during the Fall of 1916. Thirteen of these collections contained trematode infections. Among these (Table I) Iymnaea proxima was taken five times Irom five different localities, Physa gyrina was taken ten times from eight different localities, and Planorbis trivolvis was taken twice from two localities. An analysis of this table 



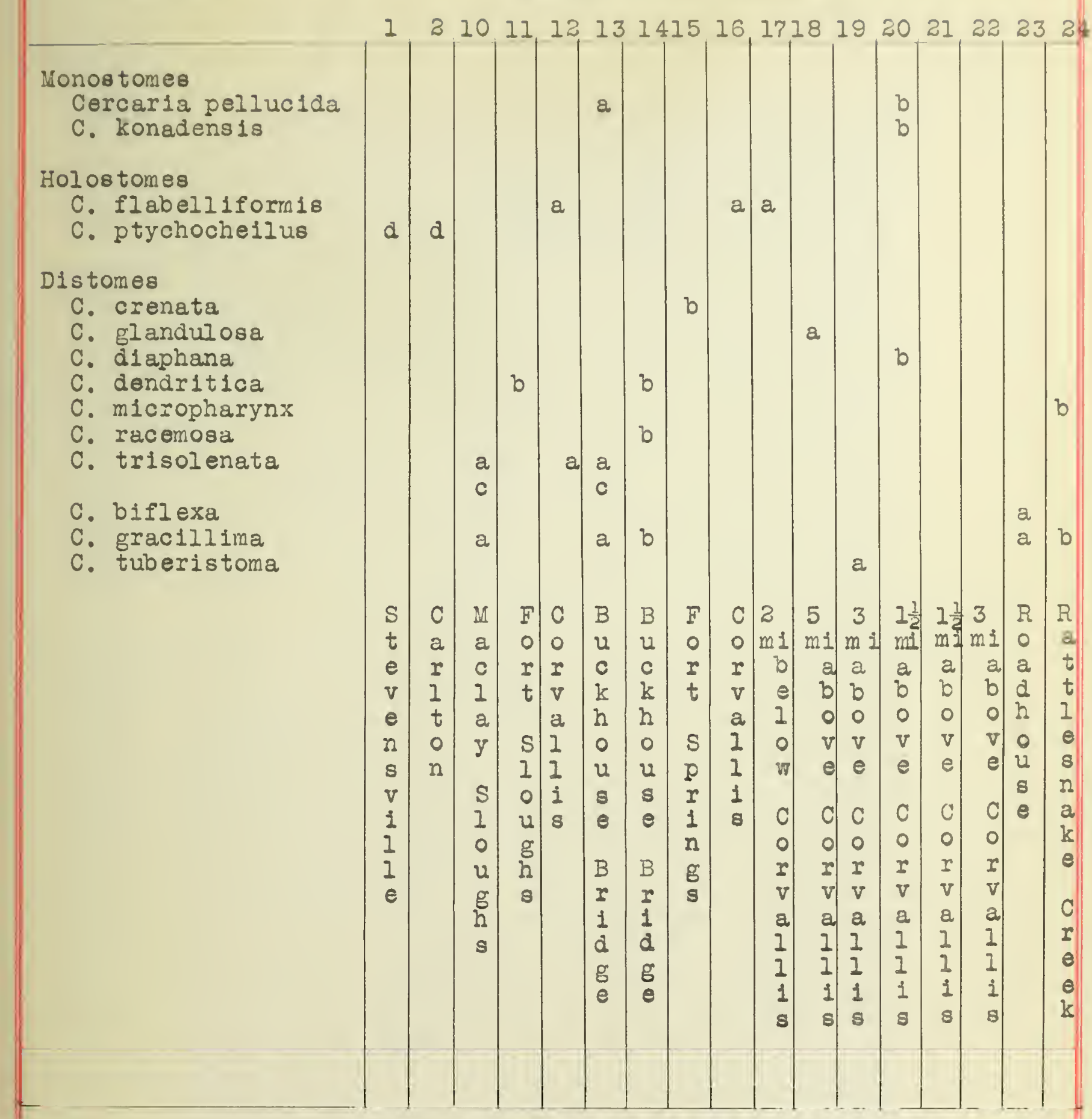

Table I. Distribution of Cercariae in the Bitter Root Valley. $a=$ Physa gyrina, $b=$ Lynnaea proxima, $c=$ Planorbis trivolvis, I= Ptychocheilus oregonensis. Compare with map (pagel0A). 



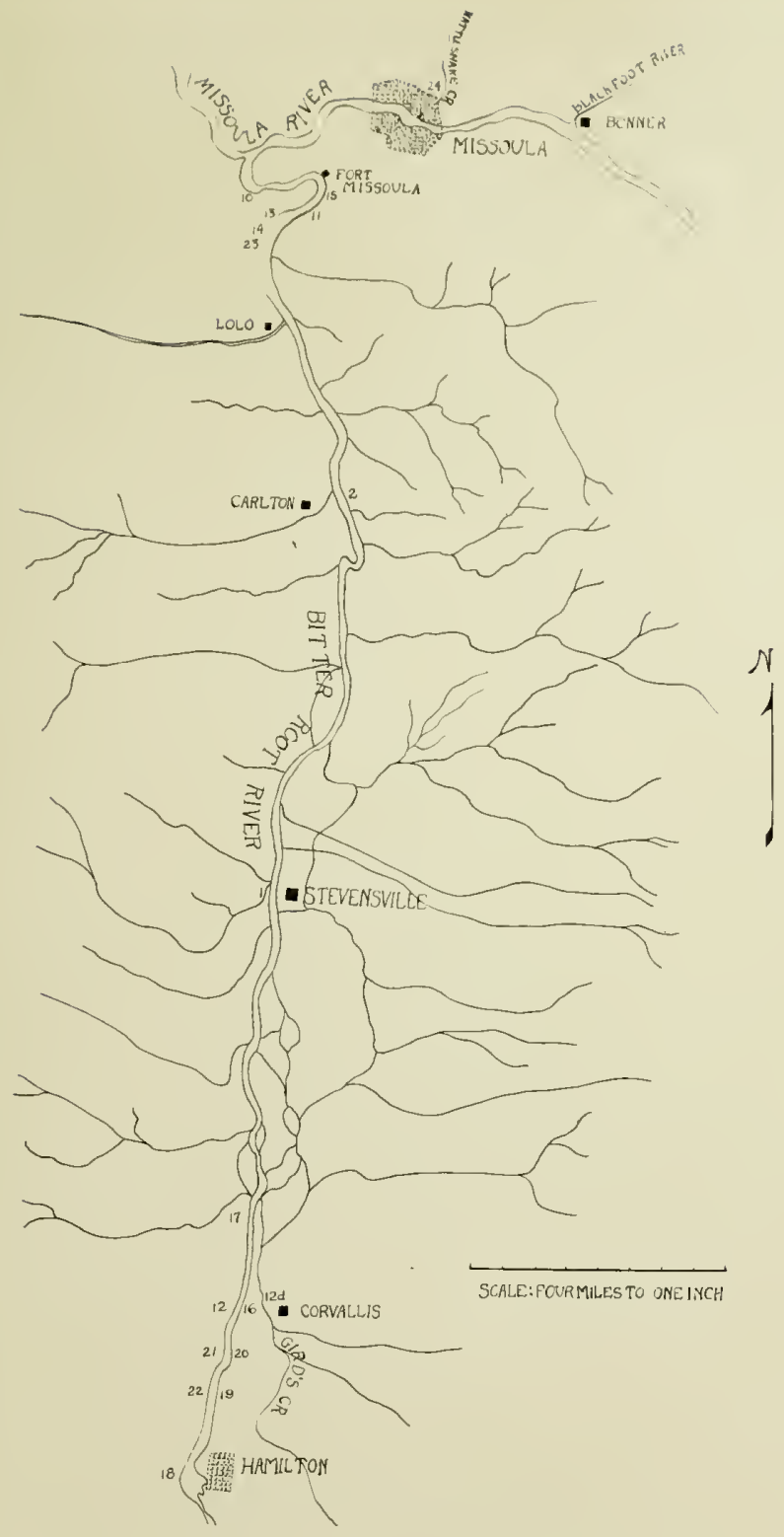

Textfigure A.- Sketch map of the Bitter Rot River Lontana and its tributaries, together with its confluence with the Clark's Fork of the Colunbia River. 



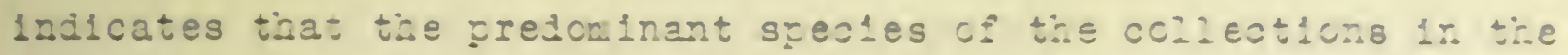
Loper reashes of the Vally is the Physa, ritle tiat of tie Icrez reaches is the iymasa, wile the Planorbis was icurd oriy 1 to the lower reaches of the Vailey, aru there \&.. small rumeers.

The infecticn records show tiat tho host is not syeciflc. In the infecticn of tise nollusc with Cercaria celiucita tia host

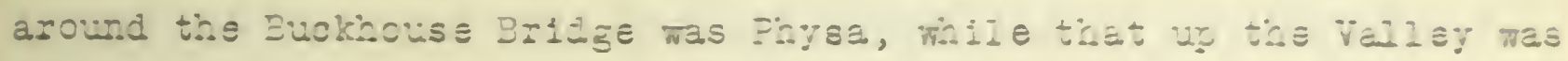

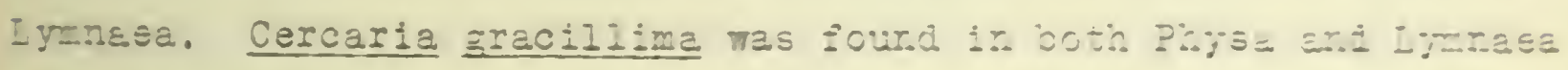

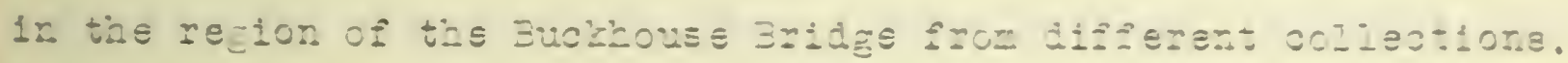

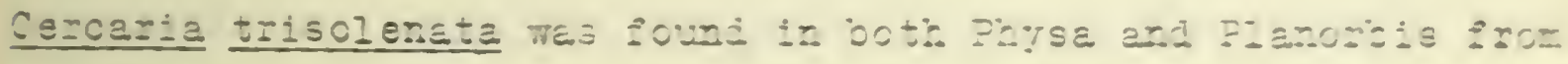

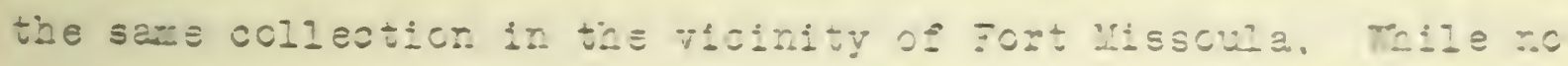
razasite species mas fouri in more than tat of the three snatis of

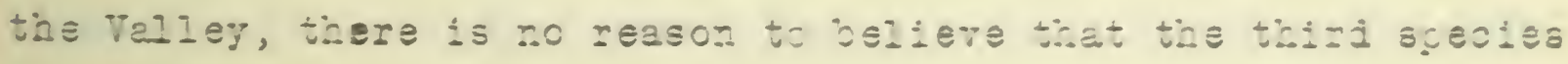

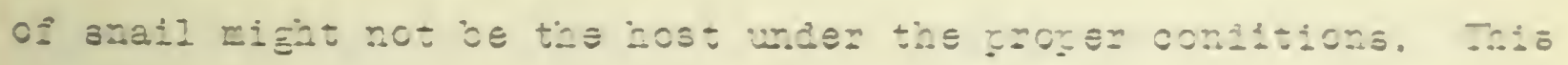

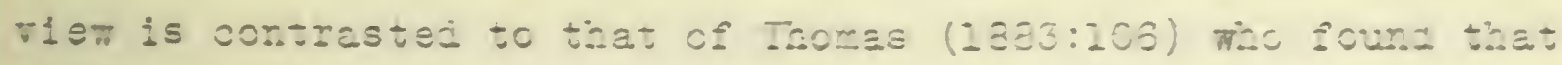

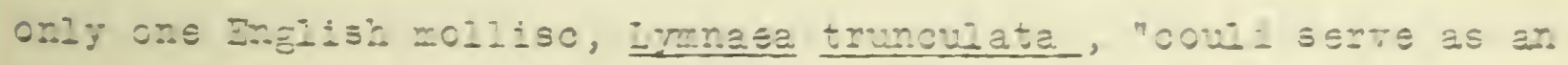

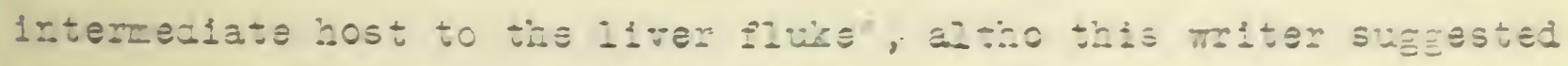

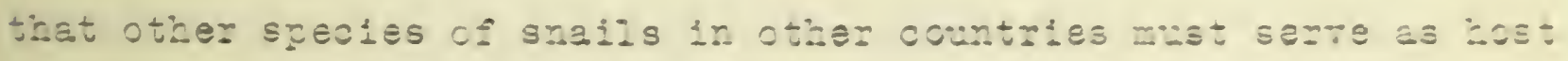

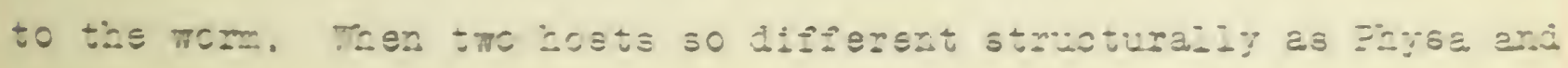

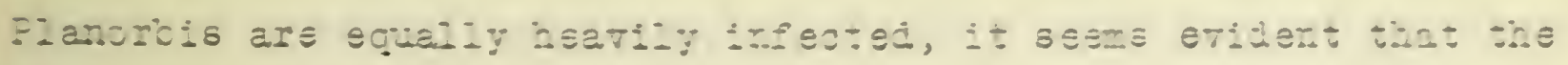

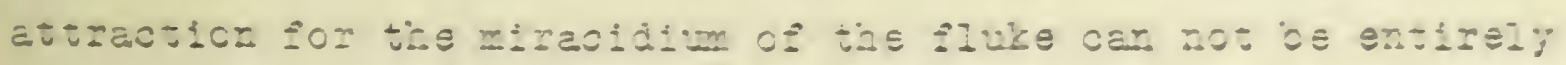

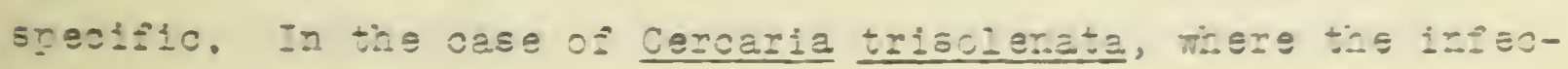

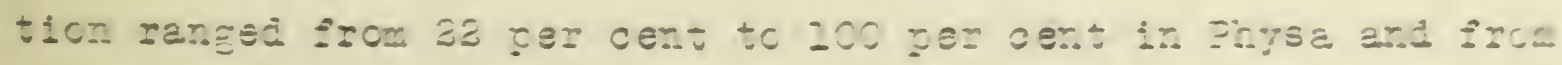

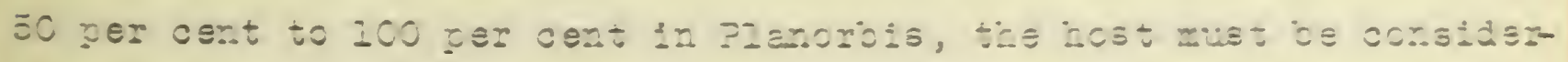

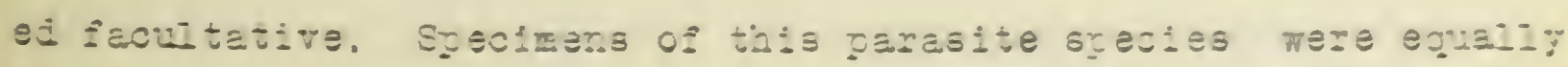

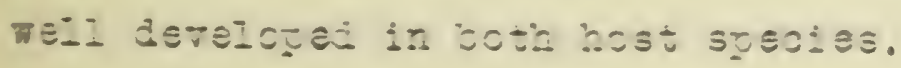

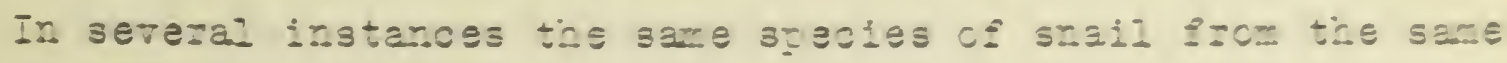
collection ¿arcoral two or more cercar:ae. 

For example, (Iable I), at the Maclay Sloughs both Cercaria tr1-

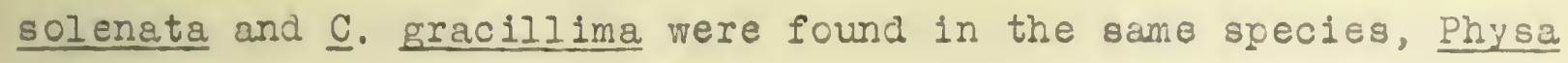
gyrina, in fact in the same host individual. This case is paralleled by the record of Cort (1915:55), where the sporocysts of Cercar1a polyadena Cort and $\underline{C}$. reflexae Cort were found within the same liver tissue of Lymnaea reflexa. However, Ssinitzin (1911), in an examination of several thousand gasteropods of six species, in which were discovered twenty-one species of cercariae, makes no record of two species in the same host individual. Hausmanm(1897: 16), in referring to the dominance of one parasite species in the individual host, regards this phenomenon as a biological antagonism. In the collection of Lymnaea prexima from the Buchouse Bridge three species of agamic trematodes were found as parasites, $\underline{\text { Cer- }}$ caria denaritica, $\underline{\text {. }}$ racemosa, and $\underline{\mathrm{C}}$. gracillima. In such a case

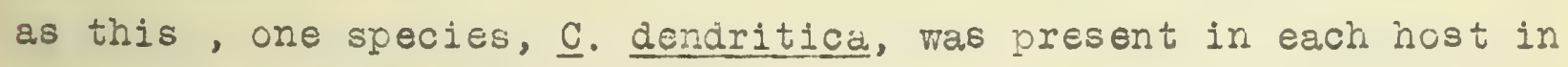
large numbers, while $\underline{C}$. racemosa was less frequent, and the third

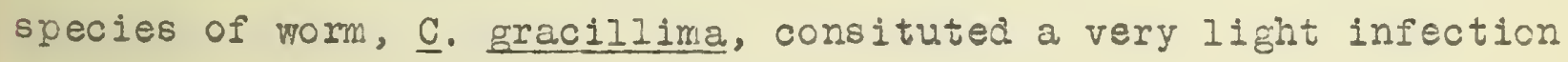
in only one of the thirty-two snails examinea.

Turning to the per cent of infection in the snails collected (Table II), we see inmediately that a very heavy parasitism exists. The data are the more significant when compared with the records of other investigators. Cort (1915) gives detailed data for eleven species of molluscs coliected from nine localities. The collections were made in the Fall of 1913. The least per cent of individuals infected was 1.4, for Pleurocerca elevatum, secured from the Sangamon River at Nohamet, Illinois. This mollusc contained the larval parasite Cercaria megalure. The heaviest infection recorded by Cort was that of $\underline{\mathrm{C}}$. 1 socotylea, where an 18 per 

1. Cercaria pelluciáa

¿. Cercaria pellucida

3. Cercaria konadensis

4. Cercaria flabelliformis a

5. Cercaria flabelliformis a

6. Cercaria flabelliformis a

7. Corcária ptychocheilus d

8. Cercaria crenata

9. Cercaria glandulosa

10. Cercaria diaphana

1]. Cercaria dentritica

12. Cercaria dendritica

13. Cercaria micropharynx

14. Cercaria racemosa

15. Cercaria trisolenata

16. Cercaria trisolenata

17. Cercaria trisolenata

18. Cercaria trisolenata

19. Cercaria trisolenata.

$\infty 0$. Cercaria biflexa

6. Cercaria gracillima

2. Cercaria gracillima

23. Cercaria gracillima

34. Cercaria gracillima

¿5. Cercaria gracili ima

26. Cercaria tuberistoma a

b

b

18

16

16

34

10

12

6

22

a

b

b

b

b

b

a

c

a

a

c

a

a

a

a

2

b

a

16

14

29

32

39

12

1

8

18

2

71

12

18

29

71

32

19
1

5.5

5

31.3

31.3

5

14.7

3

30.0

25.0

100.0

13.6

40.0
31.3

35.7

10.3

56.3

10.3

12

100.0

100.0

25.0

22.2

50.0

7.0

8.3

5.5

17.3

46.5

3.1

5.3

Table II. Infection Record of the Cercariae of the BitterRoot Valley. $a=$ Physa gyrina, $b=$ Iymnaea proxima, $c=$ Planorbis trivolvis, a- Ptychocheilus oregonensis. 

cent infeotion was found in Planorbis trivolvis from Urbana, III1no1s. The average infection from Cort's eleven species records is 8.5 per cent. Ssinitzin(1911) has recorded data from twentyone species of cercariae described by him for the vicinity of the Black sea at sebastopol. In many cases his records show a iniquely low parasitism, practically insignificant from a pathological point of view. Out of 1159 injivialuals of Rissoa venusta only one each was infected with the larvae Cercaria cribrata and $\underline{\text { C. meten- }}$ tera, or, in each, only a 0.06 per cent infection. The heaviest infection found by this investigator among these tmenty-one species was that by c. zernowi in Cardium exiguun, 7.0 per cent. The average for the twenty-one species is only 1.34 percent. In the cases of the larvae fourd in Cerithiolum exile and Rissoa venusta, the percentage of infection is so low that no parasites woula have been found had not a large number of snails baen collected and examinea.

In contrast with the parasitism of these mollusca with cercariae is the infection with the agamic trematodes in the Bitter Root Valley. The lowest per cent infection is that with Cercaria gracillima in Lymnaea proxima from the Buckhouse Briage, 3.1 per cent. Frow a different slough in the eame locality one month later a 46.5 per cent infection with this species was found in Physa, inicative of a fluctuation of the worm within a very circumscribed area. The least infection of Prysa with $\underline{\mathrm{C}}$. gracillima is from the Maclay Sloughs fartier dow the River, 5.5 per

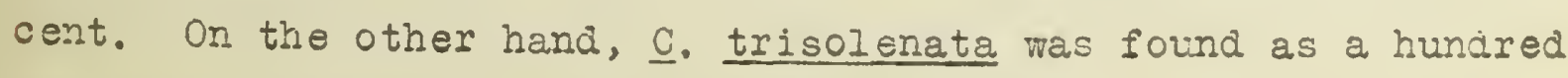
per cent infection in both Physa and Planorbis collected from these same sloughs. Taken as a whole the infection average for the 

B1tter Root molluscs is 39.02 . The average by host species 18 slightly different, 24.8 per cent for Lymaea, 25.16 per cent for Physa, and 75.0 per cent Ior Planoro1s. Leaving Planorbis out of consideration because of the few specimens collected, we have an average infection of over 24 per cent in the hosts Lymnaea proxIma and Physa gyrina.

III. Methods of Investigaticn.

Preliminary examination of several collections of snails during 1914-1915 gave ths writer an insight into the possibilities of the study of the agamic trematodes of the Bitter Root Valley. Plans were made accordingly and an intensive stuay of these forms was made from live material shipped to the writer at the University of Illinois during the Fall of 1916. The majority of the collections were made by Mr. Norbert sager of iissoula. A sketch map (text fig. 1) indicates the focation of each collection. The snail collections are numbered 10 to 24 inclusive, and include all three snails from the lower reaches of the Valley and Physa and Lymnaea from the upper reaches around Corvallis. The snails were shipred in damp green moss and arrived in excellent conaition. The shipments were arranged so that one collection had been examined and a careful stuay made of the live parasites before the next shipment arrived. In this way about a week was allowed for the study of each species from the living material.

The observations on Iiving material gave data on the stages of development within the mollusc, on the methods of lccomotion, on excystment, and on the excretory system.

In every species of larval trematode secured from the snails 

the mother reaia or sporocyst was found. In no cases were sporo-. syst and redia found in the same species. In no case were mother and daughter sporocyst found, altho it is the writer's belief that in certain groups tiese two generations are prozuced seriatim, as Leiper has recorded them for Schistosoma hrematobium larvae (1915). In one case, in the holostome larva, Cercaria flabelliformis, three generations of rediae were found, altho along with thew were young cercariae. Mature cercariae were found ir all species of flukes aiscoverea, anci usially all stages of development, in series from the parthenogenetic ovum tc the mature cercariae. The worms were removed from the infected tissue and piaced in a watch glass in 0.3 per cent saline solution. The change from the host tissue to the saline medium uslally calised rapid movement. Ordinarilly this mobility is due in part to the lasing and turbine action of the tail, altho the cercaria is able to crawl abcut with ease after decaudation. In species where the corcariae cast off the tail ani encyst within the primary host (the snail), the tail seems to be of questionable value. In forms like the furcocercariae, where there is a free-swiming stage previous to the infection of the definitive host, the tail is an essential organ or locomotion.

With the exception of the furcocercariae, encystment has been observed in all of the groups studies. No cystogenous glands have been found in either of the two species of furcocercarias discovered, and it is altogetner probable that encystment is not a preliminary step to a change of host in this group.

It is essential that the excretory system be studied in the living material. Aside from the vesicle and the main trunks of 

this system, very little can be made out of this system in the preserved materlal. The delicate structure of the flame cells and the finer caplilaries makes it expeilent that these organs be es amined in living specimens, for in fixation they aro likely to collapse, even with the most careful technic.

The organs of the digestive system come out equally weil in living and preserved mounts. Sorne systems, as a rule, can be made out only from preserved and stained material. The most important of these is the genital complax. For all oruinary purposes the material was fixed in Gilson's reagent, al tho equally good results were obtained from a corrosive-acetic fixing agent. From the preserved material toto mounts and sections were made, using Delafieli's hasmatoxylin and Ehrilch's acid hasmatoxylin stains. A strong counter-stain of eosin in the sections brourint out renarkably well the nerve fibers of the woms. Care was exercised to keep the mounts acid fres, and for that purpose all reagents except the destaining reagent weie made slightly alkaline with dessicated potassiurn acotate. Some specimens were fixed without any acid fraction in the reagent in orier to preserve tine excretory granules. These granules, as well as the mucoid cyst membrane of the encysted worm, gave beautiful biuret and xanthoproteic reactions, suggesting a tyrosine compound. 



\section{Comparative Norphology and Histology}

The progress in the morphological and histological knowledge of agamic trematodes is wrapoed up in the development of discriminate observation and interpretation on the part of investigators. This has been aided in no small degree by the use of better technic and by better optical equipment. But it is for the most part the observer's own expectation that differences must exist in larvae, and his determination to discover faithfully and accurately such a differentiation of structure, that has brought about progress in this line of investigation. No clearer conception of the change in point of view can be obtained than by a contrast of the statement of a worker in the field six decades ago with the expresgion of Crarles Seugwick ininot just ons decaù ago. In his Symbolae ad Trematodum Evolutionis Historlam La Valette (1855;34) recites "nonnuliae Trematodum larvae tam exiguam offerunt differentiam ut discrimina earun characteristica vix comonstari queant." Mnot (1897; 928) voices the modern point of view in his declaration that "it is not true that all embryos are alike; on the contrary they show class, orainal, and generic differences froul one another." Mile the witer fully agrees with the iaea that the most natural way of correlating larval trematodes with the adult forms is by a knowledge of their life histories, yet such a correlation is not always possible. Looss (1896) probably had the cercaria of Schistosoma hamatobium among some of the furcocercariae that came under his observation, yet he was forced to admit (p.167) that "tous ces efforts ont ete, quant a la Bilharzia completement negatifs." With the idea in mind that not only the fundaments of the adult trematode are found in the mature cercaria, 

but that even the main descriptive features of the adult are already present, so that the worker can recognize the aduIt in the lurva, tho writer ias attaonect this part of the prusem. Wrizo It has been impossible to show species correlations between larva and adult, it has been found in the course of the investigation that the larva shows clearly the fanlly features that have been inferred hitherto only from the "bluncierbuss methou" of life-history investigations.

It is probably true that none of the adult trematodes genetically related to the larvae studied. have been described. Moreover, there is just as surely the possibility that the characters common both to larva and adult have been overlookea in the study of many adurt species. It is neediess to observe here that the writer has been confronted with the problem as to what characters of the larva are ephemeral and what ones are common to cercaria and adult trematode. A thoro analysis of the groups stuied, including Monostonata, Holostomata, and Distomata, gives convincing proof that the most constant systems in larva and adult are the nervous, genital and excretcry systems. Such systems and organs as tail, cystogenous glanas, and stylet are distinctly larval in nature and may or may not show the same relationship as the natural grouping based on characters common to both larva and aล่นI.

\section{Embryology}

By "Iarval trematode" is commonly understood the phase of the Ife-history from the fertilized egg to the adult trematode. This is truely a wrong conception in the light of the observations of investigators from early times dom to the present. These 

workers have recognized sporocyst and redia as "nurse" to the progeny. In other words, they are parthenogenetic mothers, and as such are rature individuals. Ssinitzin (1905, 1=01, 1911) has made a wise separation of sporocyst and relia on the one hand from the cercaria on the other. The mature sporocyst and reala he groups together unjer the term parthenita, or partienogenetic mothers. This term is usea thruout this paper to define the mature sporocyst and redia as distinguished from cercaria orlarval trematudes.

The homology between cercaria, sporocyst and rejia in their early stages of development is recognized by Schwarze (1886:54), who compares his studies on the cercaria's development with that of Schauinsland on miraciaia of aistomes ana the gasterostome Aspiuogaster conchiola (1853). Schwarze notes the similarity of the "cuticula", the slouching off of the epidermis, the location of the solid entoblast, which aivides so that a portion comes to Iie next to the ectoderm and another part around tie gut. He goes on to say that the homology is very aprarent. "Die Keimzellen aes Embryc entsprechen den Genitalzellen der Carcarie, die etwas abgeplatteten Epithelzellen des Embryo den Meristemzellen der Cercarie." He observes the similarity of the excretory system in miraciaia, reaila and cercaria, and "ferner sina sie ebenfalls mit einem Iivervensystem ausgestattet, welches dis grosste Aehnlichkeit mit demjenigen aer Cercarien hat."

Since the miracidium, relia, and cercaria are not, on last analysis, three parts of one life-history, but more exactly three or more complete life-histories, it would not be too much to expect, then, that the origin of germ layers in miracidium, redia 

ará cercaria is the same. All three Eererations arise by the cleavage and development of a single germ cell of mesoderhal ori51n. In the miraciaium the cell is always fertilizei; in the redia and cercaria it is always parthenogenetic. The observations on the similarity of origin of these cells are extensive, yet mostly isolatea, and deserve re-emphasis.

Whe exact method of development of incivisuals within the sporocyst or redia has been amatter of diversity of opinion. In general one of two views has been supported by investigators, buving or parthenogenesis. The earlier writers who considered the origin of the germ balls described them as arising endogenously. Thus Noulinie (1856: 130) vrites:"les cercaires naissent, comme nous l'avons vuee en parlant des sporocystes, de gemmes plus ou moins arronais qui se forment dans I'interieur de ces denniers lorsquilils atteint leur|sevellopement normal". Then the question arose whether or not the germ ball arose from the ordinary tissues lining the body cavity of sporocyst or redia, or whether special cells were set apart as germinal epitheliun. Leuckart (1886:113-125) asserts that in all cases germ balls arise only from those cells which remain unquestionaly embryonic. He distinguishes between the conjition in rediae and sporocysts, for in the former he found a specializea germinal epithelium, while in the latter all of the cells of thebody wall remain undifferentiated in character, and in consequence are capable of germ cell probuction. Thomas (1883: 115) found for the sporocyst-redia generation of Fasciola hecatica that tre germ balls wich develop intc rediae arise in part from germinal cells already present in the embryo (sporocyst), but that "they gain an increase in their numbers by the proliferation of 

cells lining the boay cavity". In the rediue proaucing cercuriae (1.c.1:5) he asserts that the majority of the embryos seem to be formed from the transformation of cells at the posterior end of the red1a. Cells from the bouy wall become enlarged, and each of these cells unaergoes segmentation, giving rise to a morule. Locss (189a: 156,157 ) is definitely committed to the view that any portion of the epithelium lining the boay cavity is capable of producing germ balls., but, as a matter of fact, only the posterior end (the vegetative end) performs such service. Later (p.167) Looss speaks of the developmental stages as a metamomosis composed of several generations, in no sense comparable to carthenogenesis. Hasmell (1903: 500,501) describes for the sporocyst of an echinostome larva the development of embryos from a single ovarian mass at the posterior end of the boiy.

Within more recent years the problem of the origin of germ balls has been centered around the critericn of the formation of polar bodies. Coe(1896: 56z) found no palar bodies in the germinal epithelium of the sporocyst and redia of Fasciola hepatica. Because he founc three small granular bocies attachea to the germ balls of Distomum duplicatum sccrocysts Reuss (1903:470) concludse that maturation occurred. Tennent's work on Bucephalus haimaenus (1906: 649) supports the argumert in favor of the orisin of tise germ eells from the walls of the boay cavity. After the germ cell passes into the bociy cavity a "polar bociy" is cut off. Later Tennent has found that there are three cells in the proximity of the germ cell. two of which seem to be the result of division of thefirst cell. Rossbach (1S06: 433) finds no cells which he is willing to call polar bodies. He conciudes that the small cells near the epithelium 

are not polar bodies because 1) their walls arc not fcund in alrect continulty with the germ cells,z) the cells called polar bodies by Feuss are normally present during develocment of germ ball, in Miracidia, in sporocysts, in rediae, and even in the ovary of sexually mature trematodes,3) theyare more abundant in the younger sporocysts and rediae, and 4) they are present in larger numbers than three's. Finally Cary (1909), in his study of tre germ cells of an anphistome sporocyst, has found that the germ balls arise from cells of the body wall which mature without realiction and throw off one polar body.

The contribution to this problem of the meaning of the proliferation of perm balls described ir this paper is based on the development of the germ cells in the rediae of the holostome, Cercaria flabelliformis Faust 1SI\%. The sections from which the study of aevelopment vas made were cut in a frontal plane, 7u thick, and stained with Delafield's haematoxylin. In the anteri or part of the mother reaiae large germ balls of both rediae and cercariae are present. The germinal epithelium is confined to the costerior fourth of the wall lining the bcay cavity. In some of the larvae-rediae within the mother rediae the earlier stages of the history of the germ cells have been studied. This has enabled the writer to secure a series of stages of the eerm cells all the way from the probabl a derivation of the mescoerm tissue from the base of the gut up thru maturation and segmentation.

At a stage in the aevelopment of the reaia when the archanteron is represented by about eight or ten large vesicular cells (Fig. 45), two striking types of cells are noted in the bojy cavity. Around the gut at the anterior end of the worm are a number 

of nerve cells (n.c.), characterized by their multipolar outlines aru their snull, wexsely oramular jucle1. The uther type ct cell is found wandering out from the blina end of the gut and spreasing thru the body cavity. Some of these cells come to lie against the wall of the cavity, and at first apear as protrusions of the well; layer they seem to constitute a loosely formea inner layer of the wall. Other cells of this type are found free in the body cavity. The majority of these cells that have wandered out from the base of the gut are oval in shape, and have attached to them on one side a small, nodular protrusion, consisting of the film of cytoplasm around a densely granular nucleus.

All of these cells, whether attachea to the body wall or not, are to be regarded as germ cells, based on their present structure and future behavior. The small nolules are polar bodies Figure $46 \mathrm{H}$ shows this body in process of formation. The mitotic figure is in the anaphase stage, and was found in a germ cell free in the boly cavity of a young dalighter redia. These data on the origin of the germ ceils fromthe specialized germinal mass at the bilnd end of the gut support the thesis of Leuckart (1886:123) and Schwarze (1886: 48,49), that the cells have preserved their original embryonic character. The fact that the production of the polar body and consequent maturation of the germ cells takes place in cells next to the body cavity as well as in those free in the body cavity, explains the observations of Thomas (1883:115) that some of the cells from which the gern balls are derived are "the germinal cells of the embryo or cells derived from them by division, others are formed by a proliferation of the eoithelium lining the cavity of the sporocyst", since these tmo grougs are traceable back 

to a conimon inception at the base of the gut.

A description is now given of the stages in the series of the germ cells in support of the view that the germ cell is a true ovum. In its unmoaified condition the germ cell is moderately inconspicuous, similar in all respects to an undifferentiated parenchyma cell. As it begins to change, the cell enlarges, the cytoplasm becomes granular, with many interstitial vacuoles, and the nucleus ccmes to have a clearly outlined membrane wall. Frequently the chromatin material is massed into a karyosome (Fig. $46 \mathrm{~A})$. The chromatin mass now becomes colong ( $F i g .46 \mathrm{~B}$ ) and after considerable growth becomes coiled into a thick skein (Fig. $46 \mathrm{C}$ ). The next stage ( $F i g$. $16 \mathrm{D}$ ) shows the division of the skein into eight chromosomes. These chromosomes arrange themselves in an equatorial plate, and soon show a longitudinal splitting. One of these (b) is precocious in its behavior. It wanders toward the edge of the nucleus and divides $\left(b_{1}, b_{2}\right)$ while the other seven chromosomes remain with their halves still in contact. The precocious chromosomes take up positions toward the poles of the cell (Fig. $46 \mathrm{G}$ ). The other chromosomes then aivide and migrate to opposite poles (Fig. $46 \mathrm{~F}$ ), one of these daughter grougs being constricted off as a colar body (Fig. $46 \mathrm{I}$ ). As a result of this process eight chromosomes separate by longituainal splitting, so that half of each goes into the polar bocy and half renains in the cell. The polar boay remains in cytoolasmic connection with the ovum while the latter undergoes another division. As in the previous aivision, simple mitosis occurs. The chromoscmes $\underline{b}$ precede the others in separation into component halves (Fig. 46 I). In a late anaphase of this second division (Fig. $46 \mathrm{~J}$ ) the polar 

boay may ilviae, altho this is not always the case.

"his sccond division is not a nart of the maturation, for that has been accomplished by the expulsion of the single polar body: It constitutes the first division of the mature ovum. After this (Fig. 46 K) the polar body is entirely separated from the blastomeres (Fig. $46 \mathrm{~L}$ ) and disintegrates. Hence maturation consists of a single mitotic division with the extrusion of a polar bocy, and takes place without any realiction of chromosomes. In other words, t:e process is one of true parthenogenesis.

The somatic chromosome count of the developing germ ball is eight, consisting of seven ordinary chromosomes and the precocious inaividual. In support of this statsment is the count of each of tre first two blastomeres (Fig. $46 \mathrm{~K}, \mathrm{~L}$ ), and the chromosome complex in the late metaphase of an enjoderm cell of a morula (Fig. $46 \mathrm{i})$. In the latter the count is double,e.s., sixteen, in view of the previous splitting of the chromosomes artecedent to separration into the daughter chromcsome groups. The consistent tendency of the chromosome $b$ and its descendents to separate from the chromoscre mass and to divide before the other seven split, suggests the possibility that this chromosome 18 a heteroscme, two of which Lindner (1914) has found in the adults of Schistosoma haematobium.

In the case of tine germ balls that never reach the body wall, the process of maturation necessarily takes place free in the body cavity. For those celis which lodge against the wall and even fuse with the wall, the process of maturation and cleavage into two blastomeres takes place vinile the ovum is still in contact with the body wall. At this time it is set free and allowed to develop into a geim ball. 

In the older matire rediae (Fig. 44) the epithelial layer of the body wall lining the body cavily consists of a syncytium in which nuclei are arranged irregularly. The cell boundaries become distinct only as maturation of the cells approaches.

Leuckart (1886:1 $\approx 4$ ) has stated that it is relatively long after germ ball formation before it is evident whether the embryo is to develop into a reiia or ceicaria. Waile the chromosomal history in the rediae of Cercaria flabelliformis shows no difference between cells which develop into daughter rexiae or cercariae, the cytoplasmic history of this species is incicative of the generation of the offspring at an early date. The cytoplasm of the germ cells which aevelop into rediae is granular al tho quite transparent. It stdins a delicate lavender with Delafield's hasmatoxylin. On the other hand, from the very outset the cytoplasm of the cercaria type of cell is fibrillar, with many large intermediate vacuoles. It stains a depo magenta with tise same aye in the same section as the rediaerova. Figure 46 I represents the first cleavage of the cerciria embryo. The chromosome count is identical to that in each blastomere in a redia-forming embryo. Subsequent divisions are difflcult to follow on account of the opacity of the cercariae-gern-balls. It is very evident, nevertheless, that differentiation of layers and organs takes place much more rapidly in the cercaris-ovum than in the redia-ovun. The arguments produced by Rossbach (1906:43'), to show that there are no polar bodies given off by the gem cell, do not hold for cercaria flabelliformis. The polar boalas have been found not only in cytoplasmic continuity with the ovum, but in the actual state of mitosis preceding the separation of the polar nucleus 

from the germ ball. Dark granular bodies within the redia which may be confused with polar bolies are the nuclei of the nerve cello in the anterior part of the larval redia, and the ectodem cello of the germ balls in the boly cavity. Yet a carefil histological stuay need lead to no coniusion in this matter. Folar bodies are indeed more numerous in the young realae, since this is the period when the majority of the germ cells free in the bozy cavity throw off the polar body and mature. Altho Tennent has found three bodies similar to those designated by authors as "polar boûies", no authentic proof is recorded of more than one polar extrusion in the maturing germ cell of a reaia or sporocyst.

In sumnary, it may be said that the study of the germ cells in the rediae of Cercamia flabelliformis supports the thesis that true parthenogenesis takes place here; that the gem cells are traceable to a mesodermal cell mass in the region of the blind end of the gut; that a single polar boxy is extruded; and that maturation takes place without resuction.

It is not surprising that the details of the germ layers have not been worked out in the fertilized trematode egg, because of the yolk inclusions wich obscure developmental stages and no doubt modify the behavior of the segnenting cells. Yet it is regrettable that no attempt at the precise origin of the germinal layers has been made for germ balls within the sporocyst or redia. Without any effort at this exactstuiy of the problem the writer has followed in tine living redias of Cercaria peliucida and . konadensis, and in the sporocysts of $\mathrm{C}$. denoritica the development of the germ balls from the single mature ova, thru unequal divisions into two, three and five cells, up to the morula stage. 

Might one not preaict for the Digenea some such cell Iineage as has been workel out for the Iurbellarian, Planocera inqu1lina Wheeler by Surface (1907)? The only existing account for Trematoda, that by schwarue (188b), is entirely unsatisfactcry and incomplete. His sumary $(0.55)$ of the devalopment of the cercaria ana embryo is open to question on the following grounds. According to him, the "cuticula" is ectoblastic. He derivas the ganital organs from genital cells, the location of which is uncertain. Lxcretory, nervous and connective tissue arise alike from a vague mass of internal cells called meristem cells. Looss (185z: 164) frankly confesses that he does not know how the nervous system originates," so dass ich mich einstweilen begnuegen muss mit dem Hinweise auf ein Wort, mit dem Vater Goeze sich einst kurz und buenaig auf der Verlegenheit half: genug, es ist da.!"

It seems not inconsistent with comparative studies of other groups more or less related to the Digenea to expect that the ectoderm gives rise to 1) the outermost layer, or epidermis, which is ciliated in tive miracisium and in all cases sloughea off before maturity, ¿) ganglion cell masses ans nerve outgrowtis, including sensory cndings, and 3) a nortion of the prepharynx region;that from the encloderm is derived the gut; and that the mesoderm is the layer from which come the excretory, genital and muscular systems, as well as the connective tissue and the secretory boiy covering of the adult. 



\section{Soorocyst and Redia}

Since the classic work of Thomas (1883) on the Iife-history of Fasciola hepatica, it has been the common custom to define the sporocyst and redia in terms of stages in the life-history of the trematode. The sporocyst is the metainorphosei miracialun, and the redia arises within the sporocyst. The cercaria is the parthenogenetic offspring of the redia and develops into the ault trematode. Wile this represents a so-called typical life history, it is worth while to inquire into the facts and see whetiner this really is a life-history, and if the outlined sequence of events is always foliomed. In scme cases the sporocyst is the mothe $x$ of the cercaria, in which case the redia cycle has been omitted. The accompanying table (III) shows, that of the fifteen species trated in this paper, eight have cercariae derivea directly from the germ cells of the sporocyst. Of the seven remaining, five are knom to come from reaiae, while the mothers of the other two species of larvae are not know.

Types of development are characteristic of certain groups. The Monostomata, Holostomata and Amphistomata and usualy the echinostome cercariae develop within rediae. The xirhidiocercarlae and the furcocercariae arise from sporocyst tissue. A considerbale moxification of a typical life-history, such as is found in Fasciola hepatica, is displayei among various groups of Digenea. V. Siebold ( 1835 ) has described a viviparous monostome larva, Honostonum mutabile, in which the miracidiuni bursts the ego-shell while it is still within the uterus. Within this miraciaium, Without any metamornosis into a snorocyst, there develops a single redia. Schistosoma japonicum has two sporocyst stages, 

Parthenita

Srorocyst Redia
Germ. kpith. - $25 \mathrm{~A}-$ ion-localized Localizel

1. Cercaria cellucida

2. Cercaria konatensis

Holostomata

3. Cercaria flabelliformis

4. Cercaria ptychocheilus

5. Tetracotyle pipientis

Distomata

Xiphidiocercariae

6. Cercaria crenata

i. Cercaria glandulosa

8. Cercaria diaphana

9. Cercaria dendritica

10. Cercaria micronharynx

11. Cercaria racemosa Echinostome cercariae

12. Cercaria trisolenata

13. Cercaria biflexa

Furcocercariae

14. Cercaria gracillima $x$

15. Cercaria tuberistoma $x$

$x+x$

$x$

X

$x$

$x$

X

$x$

$x$

$x$

$x$

$x$

$x$

$\mathrm{x}$

$\mathrm{x}$

X

x

Table III. The Parthenitae of the Bitter Root species of cercariae (and, in adition, Tetracotyle pipientis nov. spec.), together with the type of erminal epithelium. 

of which the former is covered with a sooth and the latter with a spinous integunent (Leipe, and $\Lambda$ thinson, 1915: 202). $1 / 1 \mathrm{~s}$ wom has no redia stage, for the cercariae develop within the seconiary sporocyst. Cercariae and reliae develor side by side in the rejiae of Cercaria flabelliformis.

The sporocyst is much simpler than the resia. It is merely a sac with ectuderm covering, and at times a secretory intezument From the inner wall of this sac arise the germ balls that grow into the parthenogenetic injividuals. In the simplest types the germinal cell mass consists of the entire internal layer lying next to the ectoderm. Such a type is found in Cercaria diaphana (Fig. 7S), or in $\mathrm{C}$. micropharynx (Fig. 94). In the majority of cases, however, tie geminal tissue is Iocalized at one end of the sporocyst. In two cases at least there is the differentiation of an attachment crgan at the antipodal end (… dendritica, fig. 87; ‥ racemosa, fig. 105). In the furcocercariae, C. gracillima and $\underline{C}$. tuberistoma (Figs. 147, 15\%), there is a rhizoid-like attachment at the geminal end. In these cases there seems to be some evidence for regardirg the germinal layer as localized at the end opposite the potential mouth.

The redia is the life cycle nomally developing within the sporocyst. Its organization is much higher than that of the sporocyst. There is a well-developed oral aperture, a nuscular pharynx, and a sac-like gut. There is a birth-pore iust behina the collar region, on the left side, slightly ventral. Two projecticns, usually in the posterior part of the body, xeadily differentiate the redia externally from the shapeless sporocyst. 

In the cechalic region around the pharynx there is anerve complex of highly differentiatea nerve cells and nerve fibers. These are aistinguishable as a central nerve ring, with four anterior and four posterior trunks. The posterior trunks do not develop far caudat. The integument is well developed and thick, and mucular laters within it play an inportant role in the movement of the redia, whereas the sporocyst depends entirely for its movement on the motility of the larvae within it. In the mature reaia the germ tissue is always localized at the posterior extremity of the body. The develorment of the germinal tissue of sporocyst and redia has been shom to be the result of the maturation of parthenogenetic eggs. The significant correspondence between the locallzed geminal enithelium of the parthenita and that of the cercaria may be pointed out here. In most cercariae the androeciaus germ cells are aggregated into a definite number of testicular masses, in most cases, two. In the apharyngeal furcccercariae ( the probable larvae of the Schistosomiale) the number of germ masses is larger. The data complied in Table IV, on the better knom Schistosomicae, show that the number of the testicular follicles varies from four to five in Schistosoma haematcbium, the mammalian parasite (Looss,1899: 658) to about 134 in Bilharziella polonica, the avian parasite. The origin of these testes is not described in any case. In all of the adults the sexes are separate. In cercaria Eracillima (Fig. 149) the testicular masses are proliferated from a germinal mass at the posterior extremity of the body, ventral to the excretory blader. They are numerous; some twenty-four or twentyfive masses are founa in this region at this stage of maturity. Moreover, the female cell masses are also present in the species at this larval stage, showing the animal is not primitively uni- 

sexul, but hermaphroditic. It would be only one step further back in the phylogeny of the group to assume that the hermachroaitic cell masses and the geminal epithelium of the parthenitae arose from a comion type of germ cell. In other words, the germ cells of cercariae and parthenitae ars honologous. Stages in the chylogenetic development of the geminal epithelium may be outlined thus:

1. Geminal epithelium non-localized. Example,cercaria aiaphana (Fig. 79), C. microrharynx (Fig. 94). Sporocyst cycle. 2. Germinal epithelium localizex; no mouth or suctorial apparatus. Example, . glanäulosa (Fig. 6r). Sporocyst cycle. 3. Germinal exithelium localizad; suctorial disc or attachment organ opposite germinal cell mass. Example, C. deriritica (Fig. 87), ‥ racercsa (Fig. 105). Sporooyst cycle. 4. Geminal epitheliur localized coposite a true oral aperture, with pharynx and gut present. Example, . flabelliformis (Fig. 43). Redia cycle.

5. Germinal syithelium localized and specialized into two sorts of conjugating germ cells, male and fenale isoganetes. (Theoretical).

6. Nale germ cells proliferated in numbers from the mass of germinal tissue at the posterior end of the body; female germ cells more highly differentiated. Example, C. gracilIIma (Fig. IsO). Cercaria stage of gametic cycle. 7. Germinal cells massed into a small number of specialized glands, called testes and ovaries. Example, C. pellucida (Fig. 18). Cercaria stage of gametic cycle. 



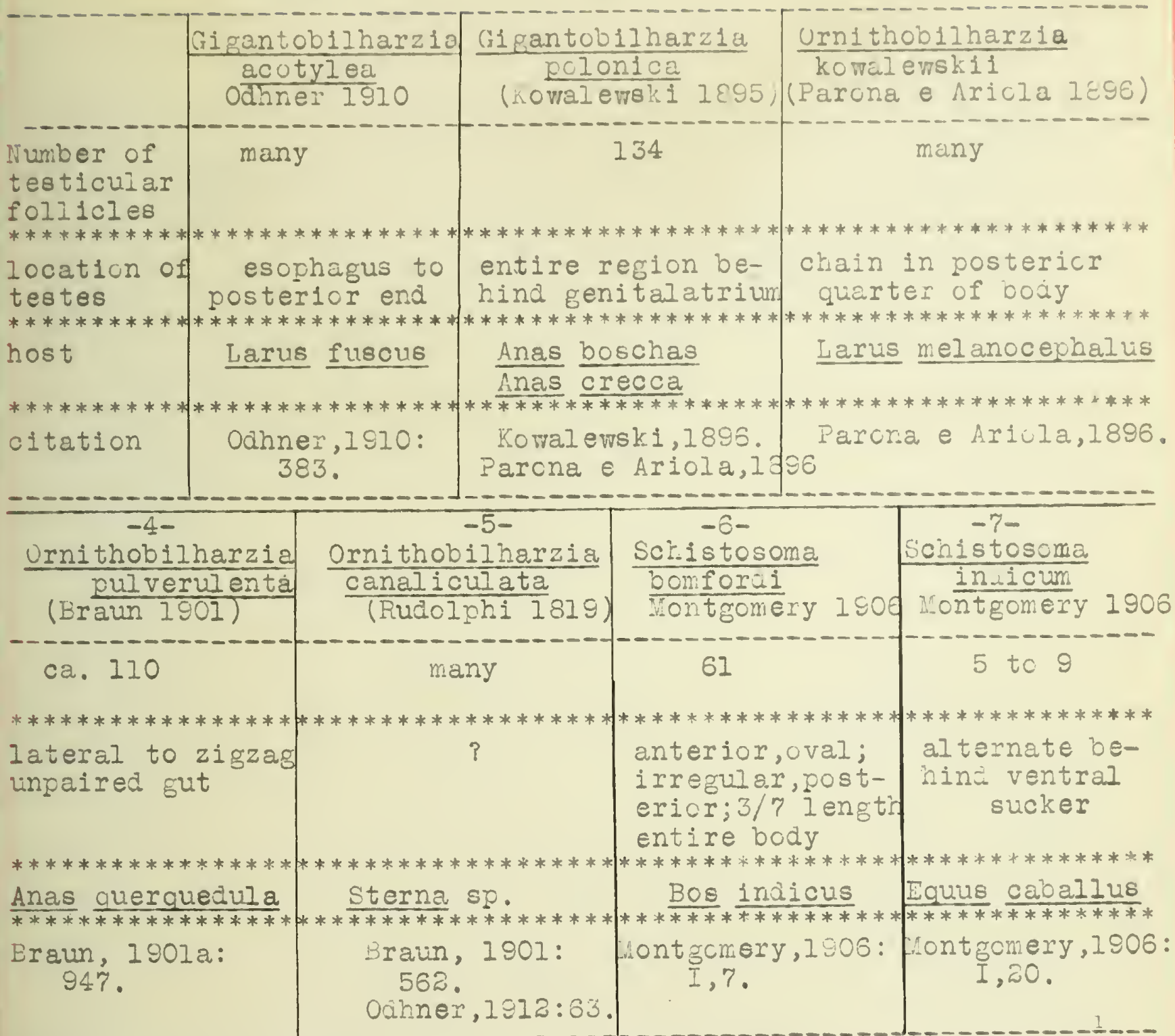

\begin{tabular}{|c|c|c|c|c|}
\hline Schistosoma & $\begin{array}{c}-9- \\
\text { schistosoma }\end{array}$ & $\begin{array}{c}-10- \\
\text { schistosoma }\end{array}$ & $\begin{array}{c}-11- \\
\operatorname{cis} i s \operatorname{soma}\end{array}$ & $\begin{array}{c}-12- \\
\text { schistosoma }\end{array}$ \\
\hline (Sonsino 1876$)$ & $\frac{\text { soindalis }}{\text { MontgomeryI }}$ & $\frac{\operatorname{manson} i}{\operatorname{sam} \operatorname{con} 150}$ & 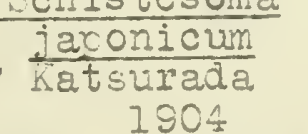 & $\frac{\text { baematobium }}{\text { Bilharz } 185 \%}$ \\
\hline & $* *$ & $* *$ & $* * * * * * * * * * * *$ & $* * * * * * * * * * * * * *$ \\
\hline $\begin{array}{l}6 \text { to } 8 \\
* * * * * * *\end{array}$ & 6 to $?$ & 8 & $\begin{array}{c}6 \text { to } 8 \\
* * * * * * * * * * * *\end{array}$ & $\begin{array}{c}4 \text { to } 5 \\
* * * * * * * * * * * * * * *\end{array}$ \\
\hline$?$ & $?$ & $\begin{array}{l}\text { small } \\
\text { area }\end{array}$ & $\begin{array}{l}\text { I imited be- } \\
\text { ind acet. }\end{array}$ & $\begin{array}{l}\text { anterior } \\
\frac{1}{4} \text { bcjy }\end{array}$ \\
\hline $\begin{array}{l}\text { sheep, cattle } \\
* * * * * * * * * * * * *\end{array}$ & $\frac{\text { Bos }}{* * * * * * i n a i c u s}$ & $\operatorname{man}_{* * * * * * * * * * * *}$ & $\operatorname{man}_{* * * * * * * * * * *}$ & $\left\{\begin{array}{c}* * * * * * * * * * * * * * \\
\operatorname{man} \\
* * * * * * * * * * * * * *\end{array}\right.$ \\
\hline $\begin{array}{l}\text { Montgomery, } \\
1906: I I, 14 .\end{array}$ & $\begin{array}{l}\text { Wontgonery } \\
1906: I I, 10\end{array}$ & $\begin{array}{l}\text { Leicer, } \\
1916: 411 .\end{array}$ & $\begin{array}{l}\text { Katsurada, } \\
\text { 1914: } 36 \% .\end{array}$ & $\begin{array}{l}\text { Lcoss, } 1895: \\
181 . \\
\text { Leicer,1916: } \\
411 \text {. }\end{array}$ \\
\hline
\end{tabular}

Table IV. Nale germ cells of the better knom Schistosomidae. 

The cercaria is the parthenogenetic offsring of the fartherital. It is a highly specializel inaividual, homologcus to the imature redia or the sporocyst. Its specialization has veen accounted for by ssinitzin (1910: 38-56) by 1) a considerable ferica of free-simming life, during wich it acquired a tail, 2) a chance tc parasit$1 \mathrm{sm}$ in the vertebrate, which was at first facultative, but later became obligatory. There are two types of modified characters to be accounted for in the cercaria, in addition to the original characters comion to parthenita ard cercaria. The tail, the welldevelored muscle complex, the nerves irrervating the muscle system, together with the salivary glands and the senscry papillae,- all of these bear evidence of a long period of independent life. When the organism became parasitic, îrst ectoparasitic, later endorarasitic, the highly developed muscular suckers with their nerve tracts were further developed, wilile the stylet organs and cystogenous glands were differentiated. The muscular specialization was of primary importance within the host, while the cyst served to protect the worm during the period of transfer from larval to definitive host.

The cercaria varies in size, altho the size for a carticular family or genus is fairly constant. Holostome cercariae reach a size of $0.63 \mathrm{~mm}$. in length and $0.35 \mathrm{~mm}$. in wizth (․ pthchocheilus). on the other hand some of the xiphixiocercarias are extremely minute, $0.13 \mathrm{~mm}$. in length by $0.09 \mathrm{~mm}$. in width (0. micropharynx). chere are two types of movement in the cercaria asicie from the apparent contraction and expansion of the body. One of these 

is concermed with the forward movement of the animal and de ends cr the cooperative action of the suctorial organs and the general iol1Iy musculature. The other is causod by the flagellate action of the tail. The novement of the cercaria alone a furward path reminds one of the rythmic action of a measurine woim. The oral sucker is always used as one organ of attachment, and the ventrdI - caudal suctorial disc supnlies the other anchorage. With tinese two organs of attachment, the larval worm applies tise oral alsc to the object of contact, while it araws the posterior portion of the boay forward by the contraction of all the longitudinal muscles. This places the posterior attachment advantageously near the oral isc, so that a relaxing of the longitudinal muscles and a synchronous contraction of the transverse muscles tirows the cephalic fortion of the worm far forward. In the forms with well developed musculature, such as monostore and echinostome species, the larva amy appear discoid on contraction, while the expanded worm w1II assume a length several times the nomal bodily length.

$\Lambda I$ groups of cercariat possess an oral suctorial organ. For the second attachment organ there is a variety of accomodations. Unsoubtedly the most aivantageously formed organ of this second type is the one found in the imphistomata, where there is a powerful suctorial disc at the posterior ent of the body.

Among the aistomes there are many types of posterior suctorial organ, ranging from those with a prominent acetabulum not far from the caudal extremity, as in Stomylotrema pictum Looss (1899: 629) to those with poorly developed acetabulum more cephalic in position. In the latter case there are frequentIy found auxiliary lccomotor organs, such as those in the posterior pockets 

of the xiphiliocorcariae. In some species there is only a sugeotion of a paired suctorial organ, as in the larvae, Cercarla cranata (Fig. 55), and C. diaphana (F1g. 75). In others there is the adi1tional spinose setal complement (‥ glanaulosa, $\underline{C}$. denlritica, and and $\underline{\mathrm{C}}$. micropharynx). These spines are of especially imrortant function on rough surfaces where the aisc can take hold with difficulty. Altho there is consi erable difference in the rapidity of movement of the various species studied, it was evident from the start that $\underline{\text { C. }}$ glandulosa was by far the most rapi- in movement of all the cercariae observed. The spinous cutgrcwth cf the acetabulum is of advantage in locomotion, catching hold where the unarred sucker can not operate (… glandulosa, f1g. 60; and C. graciliina, fig. 142).

iviscular development in the holostomss is confined entirely to the suctorial apparatus, since there is no distinct tail portion. inis type of sucker is derived from the aistone type. With the translocation of the genital openirg to the posterior enu of the body, the primitivegenital pore has come to be used as an accesory suctorial organ (eercaria ptychocheilus, fig. 47). The most unique modification is found in the tetracotyle type. Here there have arisen two Iateral accessory suctorial grooves (Fig. 4l), and lappets posterior to the acetabulum. All of these come to be enclosed in a comon pocket winich acts as a large sucking cur (Fig. 40). There is practically no locomoticn in these species, since movement is confined almost exclusively to the sucking reflex. In the monostome no acezabulum is present, yet the cercaria perforns the processes of locomotion car excellence. The pair cf posterior locomotor crgans replace the acetabulum in the measuring

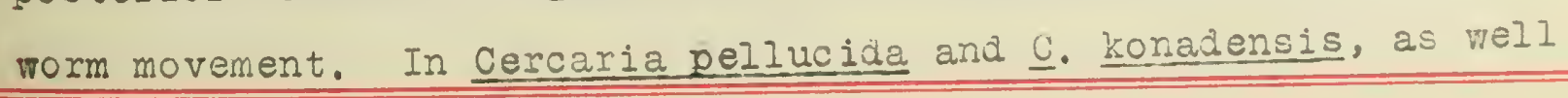



as in $\underline{\mathrm{C}}$. urbanensis, these organs consist of posterior inpocketings of the integument. In $\underline{\mathrm{C}}$. Imbricata Louss (1893:fig. 151) tiere is an internal pocket. In $\underline{C}$. ephemera litzsch (ssinitzin,1505:fig.75, 76) there are hooh-shaped spines. Cort (1915: 15) finds that they "apparently have no suctorial function, since no muscles are presont and the contral cavity contracts while the projection is extended". A careful study of living and preserved specimens of $\underline{0}$ pellucida, $\underline{\mathrm{C}}$. konadensis, and $\underline{\mathrm{C}}$. urbanensis shows that these three American species have no spinose or other integumetary modifications. However, their function is found to be distinctly suctorial, and not "analogous to setae", as Cort believes. Typical arawings for the locomotor organs of any of these three species are shom in figs. 16 and 17. As will be seen in fig. 16, there are four muscles which are attached to the cockets. By a contraction of the pair $\mathrm{Xx}$ the pocket aisc is applied to the surface of the contact body; by a relaxation of $x x$ and a contraction of $y y$ the pocket is released and pulled forward by the general bodily contraction. This has been observed repeatedly in so convincing a manner that it leaves no doubt as to the structure or function of of the organ. In adition, in C. konadensis (F'ig. 2l) a group of glands just antericr to the locomotor pockets pour out a mucous secretion at the time when the disc is applied to the contact organ. The locomotor pocks perform a similar function and in a sinilar manner to that of the secondary suctorial uisc or acetabuIun of amphistome or distome, al tho these organs are in no sense homologous.

The significance of the spines in connection with the caudal locomotor pockets of distomes has been regarded by Leuckart (1886: 

128) as deserving more than passing consideration. In Cercaria armata he considers them as serviceable in keoping the tail attachel to the body after the constriction between the two parts has become deep. Looking into the phylogenetic sigrificance of the spines of the same ceicaria spccies, Ssinitzin (1911:68) regards them as indicating a bifid ancestral aprendage of a caudal nature. In view of the fact that they actually function similarly to the locomotor pockets of the monostomes, and are more than likely the arcestors of the monostome type (Fig. 12), it seems hardly worth while to find a more obscure meaning in the structures.

The tail is the portion of the cercaria showing preeminently the adaptation of the organism to free-swimming Iife. In such forms as $\underline{\text {. }}$ setifera (vonticelii, 1914: Tav.I), ‥ pennata ana $\underline{C}$. clumosa (Ssinitzin, 1911:Tav.V, figs, 7e-79), the prolcnged fresswiming existence has given rise to setae, spines and scutes.

'the tail arises as a meiian posterior protuberance, bilaterally symmetrical, and, according to the views of Ssinitzin (1.c.), phylogenetically a paired organ. This thesis is supported, in part, at least, by the fact that the excretory trunks arise as pairea organs in both the boly and the tail. In the furcocercariae the caudal thibules remain separate in the rami of the tail and also in the "eyelet anastomosis" a.t the jumction of the boay and the tail. There develops in the tail the usual complement ci muscles, a transverse layer externally and a longitudinal group more median. Within the cylinder of muscles is the group of parenchyma cells surrounding the excretery tuloule.

'i'he tails of distomes (Figs. 99, 133) show that the exoretony vessel is a paired structure, separateả in the midale by a paren- 

chymatous partition with one or two muclei in each section of $7 \mu$. The suhistosomid larvae have, in addition, eleven o: twelve palrs of oblong cells just lateral to the excretory vessel. The tail of the monostome is characte 1 ized by extra large longitudinal muscles with prominent nuclei. The portion within the longitudinal muscle cylinder differs in structure in individual species. In C. pelluc1ja there is one ring of very large parenciyma cells situated around the excretory vessel. There are eight to tell cells to each transverse plane of $\%$. In $\underline{\mathrm{C}}$. konadensis and $\underline{\mathrm{C}}$. urbanensis tinere are glandular cells within the parenchyma ring; tiney are large and crowed with granules. In both of these specles (Figs. 25,3z) these

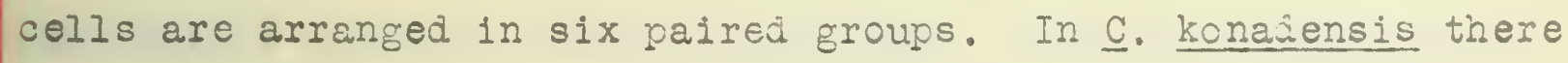
are many celis to each merber cf the group, arranged in pyramial fashion with the apex directed distally. Thus the largest cells in each group (Fig. 27) are proximal. These cells lie next to the excretory vessel. Cort has described the cells of $\underline{\text {. urbanensis }}$ thus: "Fxtending the length of the tail and forming a core are tro rows of long cells wich are close together anc have their long axes parallel with the length of the tail.... They are fuIl of heavy staining granules... There is nothing suggestive of the posEibel function of these cells". He has failed to observe tbe exact number of these cells (six cairs) and is surely in error in consisering then as a core extending the whole lengti of the tail, for they alternate with non-glandular tissue in about half of the extent of the organ. Their structure is probably glardular, but the exact furction is not apparent. In C. urbanensis these cells arise Irom undifferentiated parenchyma celis (Fig. 33). They soon appear as falciform cells in trans-ecction (I'iz. 34), searated ir 

a median sagittal plane by a partiticn arising between two interiodlate parenchyma cells, which soon differentiate irto a nuscular lamina. The lamira arises before the excretory tutules differentiate as distinct Iumina amone the parenchyma celis. Thus the bilateral symetry along the median sagittal plane 16 well show. The excretory vessel is single in the mature $\underline{C}$. Eellucida and $\underline{C}$. konadensis, but remairs paired in . urbanensis.

Looss (1893:24-28) cites the epithelial celjs of the ta1l of cercariae as good examples of "Blasenzellen", where all cell elements of the mesenchyme usually becone "Blasenzelien", and where no true glands take their place. The study of $\underline{\mathrm{C}}$. konadensis and $\underline{\mathrm{C}}$. urbanensis, together with .. gracillima, shows that axial cell. glands are present, and that they are derived from the parenchym. Horeover, where these special gland cells are not oresent, as in C. Dellucide, the parenchyma cells are more vesicular than where they are present. Yet the writer is entirely in accord with Looss's view that there are no indifferent cells renaining in the tail. The tail, when separated from the body, can not metamorphose into a sporccyst or redia, as the older witers believed (Pagenstecher, 1857: 15). 

Integument

The covering of trematodes and cestodes has boen the subject of considerable controversy. $\Lambda$ complete and lucid account of the observations and theories of investigators along this line has been Elven by Pratt (1909). The Blochmann theory (1896) assumes that "the cuticula of trematodes and cestcdes is a true cuticula morphodgically, which is secreted by the hypodermis, as in other invertebrates". A second theory, presented by Brandes (189z), postulates that trematodes have no subcuticula in the true sense of the term, and what has been considered as such is nothing more than the true parenchymatous connective tissue. Mevertheless, the body covering is a true cuticula, secreted by special glanular cells of epidermal origin just beneath the cuticula. The presence of apparent nuclei in the cuticula has revived the old ldea of Wagener that the cuticula is a metamorphosed epithelium. Goto has subscribed to this theory in his study of the ectoparasitic trematodes (1894: 6-13), defining three layers, an outer cuticula, a subcuticula, and a basement membrane. This is also the interpretation Monticelli has put on the body investment of Cotylogaster michaelis (1892:189), which he claims to possess an "ectoderma sinciziale di aspetto cuticuloide". More recently Cary (1909:646) has advocated this view. Pratt(I.c.72I) is inclined toward Leuckart's theory thet the cuticula is of parenchymatcus origin, a derivative of the peripheral portion of the parenchyma.

The species of larval trematodes studied by the writer are consistent in showing that the epidermal layer, developing into a syncytium in many cases, is present in the early stages of the sporocyst, redia, and cercaria. In the parthenitae, especially in 

the redia, this layer may persist unt1l the germ balls within are ripe and ready to escape. In the cercaria the optacmal tissue is present in early life as a syncytial layer investing the larva. In the mature cercaria it is sloughed off. The "cuticula", when present, arises from below the epidermis. It is a discrete layer undermeath the epiaermis, or it impregnates the eoidermis frcm below. In the latter case the nuclei are always superficial, usually rising above the surface as small tuberosities.

In the monostome group, the redia possesses a syncytium of ectodermal cells impregnated here and there with granules of a secretory nature. The cercaria develors a well-defined epidermis which later (Fig. 37) becomes syncytial and is sloughed off. Uncerneath this is the "cuticula", aistinctly cut off from the epidermis on the outside and from the mesodermal tissue beneath. Among the latter are the special parenchyma celis with aciculate pseudopodia, corresponding to Blochmann's "Epithelzellen" (1896:?, Taf. I,II). These differentiated parenchyma cells have no connection with the "cuticula" in the developing or mature cercaria of this group. For the hemistome cercaria (C. ptychocheilus, Iig. 54), a non-nucleated epiaernis is shom in the process of sloughing off. Underneath is the distinct layer of "cuticula". Beneath the "cuticula" is a lining of transverse and longituinal muscle fibers. Median to the complexes of the lcngitudinal muscles are the complexes of the conrective tissue. The whole structure, from tie inner wall of the "cuticula", thru to the free parenchyma, is infiltrated and bound together into a single mass by a secretion. The intimate structure of this secretion can be understood when it is explained that it is indifferent to stains. The epithelial 

cells of the complex send out lorg processes toward the intecument, so that the processes penetrate into the latter. Ihese cells surgest gland cells, concerned with the secretion of the "cuticula". They are not potentially different from the underlyine parenchyma. Among the distome larvae the writer has studied the "cuticula" problem for echinostomes, schistosomes and xirhidiocercarlae. the redia of $\mathrm{C}$. trisolenata poesesses an ectodermal reticulum in which are found large vesicular nuclei. This covering is inpregnated with large granules which are indifferent to stains. In the cercaria of this form (Figs. 128-133), there is an ectodermal layer present, very thin, with the nuclei arising from the surface as minute tuberosities. Beneath this is the thick layer of "cuticula". The epiciermis has been lost in the tail. no "Epithelzellen" are visible in the mesenchyme complex. For the schistosome larva, C. gracillima, there are definite nuclei present as minute papillations rising above the su face of the epiasmal layer. The sporocyst of this form has no "cuticula". The body wall consists cf a single layer of ectoderm cells, arrangea end to end, the nuclei of which are oval to subspherical. In the distome, $\underline{C}$. Elandulosa, the sporocyst wall is composed of a single layer of epidermal cells, with falciform nuclei. In the cercaria the epidemis is present only in individuals where the tail is still attached. Here nuclei are present in the peripheral layer of the body, but are not found in the covering of the tail. The "cuticula" is a thin envelope around the circular layer of muscles.

The study of these agamic trematodes with reference to the probelm of the integument has led the writer to set aside first of all the view that the "cuticula" is ectcdermal in origin. The ectodem is superficial, lying outside the "cuticuia". The inpreg- 

nation of this layer with cuticular granules might lsad one tc believe that the two layers are one, but the earlier history of the layers shows that this conception is erroneous. Since the secreted layer is not derived from ectodermal tissue, but rather a roduct of mesodermal cells and hence of internal origin, this investment in the irematodes may be called a tunica endogena. wo hypodermis is found in any of the species studied. Cicnseguently the BIochmann theory can not hold for these species. Lio special gland cells have been found to support the theory of Brandes. Un the other hand the evidence of this study points to the sustaining of Leuckart'e theory of the parenchymatous origin of the tunica encogena on the folloming grounds. I) In all the species the tunica encogena arises from tissue beneath the ectodermal layer. Z) In all cases wire there is an ectodermal layer only (in scorocysts), no turica eniogena is found. 5) The heaviest turica. is found in species where the parenchyma has a widely diversified potency, such as salivary, cystogenous, locomotor and mucin glands. 4) The "Epithelzelien" or the monostomes anu holostornes (Figs. 37,54) are characterized by large vesicular nuclei and vacuolated cytoplasm, similar to the "Blassenzelien of Schwarze (1886) and Locss(1893). They are modifisd parenchyma cells, differing fron the underiying layers not in potency but in location. 5) As the secretory cells for the tunica endogena these parenchyma cells have developed Iong acloular fseliopowia toward the tunica and, in the larval holostomes, have penetrated into the tunica. All of these data point toward the parenchymatcus origin of the tunica encogena. 



\section{the Parenchyma}

soon after the fundaments of the digestive and nervous systems of the cercaria are laik down, certain cells of mesodernal origin of the germ ball become ovoid and are filled with milky white granules. These are the "Stabenchenkoernchen" of the Cerman writers and the "cellules a batonnets" of the French. They develop most comonly in monostomes, amphistomes, and such distomes as form a heavy cyst. Such a cyst is more mucoid than membraneous.

Other portions of the mesodern are differentiated as the gemiral epithelium and the muscle layers. The remainder of tine mesodermal cells is for a consilerable time potentially great, and remains undifferentiated. (Louss,1853:29). Looss has compared these celis of the mesoderm to the camium of the plant. They are the "nichtveraenderten Zellen", on the multiplication of which depends the growth of the minute larva to the relatively large adult. As the animal grows the cells of this region become more vesicular, vacuoles appear within the cytoplasm, and acidophyllic granules appear within the cell. The intercellular spaces become more and more prominent. The celis are held together by bands of ragged connective tisgue wich, for the most part, is the outgrowth of the interstitial cells. Within this parenchyma complex there appear large tubular lumina in certain definite regions, and, leading into these, tubes and smaller tubulss. These are the excretory tubes; at the ultimate ends of these are found the capillaries and the flame cells (Looss, 1892: 132; Thomas, 1883: 116118). In the schistosome cercariae the main cilia group is not at the extreme ends of the ducts, but in a pocket in the posterolateral part of the main trunks (Figs. 143,145). It is of imort- 

ance to emphasize the fact that these excretury trunks and tubes are not linet by a wall of specialized cells, but are merely lumina among certain cells of the parenchyma. It seens hirhly probable that Louss's view is correct as regarls the flame or "Trichter", that 1t, too, is an intercellular lumen, 1nto which tho parenchyma cell cilia protrude, and that it is not in a hollowew-out cell. The c1lla are definitely outgromths of the single cell at the head of the capillary (Fig. 138), a cell which is differentiated from the sister cells of the carenchyma by the possession of a much smaller nucleus and densely granular protoplasm.

ssinitzin has suggeste.. the cossible relationship betreen the sex pore of the body cavity of the parthenita and the excretory system of the cercaria (1911:77-80). While certain facts point to this theoretical possibility, they seem inadequate for consideration in detail in this paper. 



\section{Nusoulature}

The ruscle systems of the parthenitae and the cercariae are, Ior the most part, confined to the peripheral and splanchnic reEions. The peripheral muscles consist of an outer series of rajial muscle fibe:s and an inner series of longltualnal fibers. A thirâ series, the dorso-ventral, which is common in the adult foris, is suggested at times in the body of the cercarla. The muscles of the intestinal tract consist of a longitudinal and a circular series.

The peripheral system lies directly beneath the tunica endogena It opens interstitially to permit the growth of the processes of the parenchyma cells which secrete the tunica endogena. The outermost layer is the circular series. It may consist of a single band of one cell in thickness or it may include a cylincirical band several layers thick (Figs. 37,54,97,128). Within this is the longitudinal series. Usually here the individual fibers of the bundes are separated from one another oy a considerable interstice. The Iibers are longer and fewer than those of the circular geries. A section of an adult trexatode shows, in adoition to these, an. oblique series of fibers. These oblique fibers give the appearance in section of a diamond pattern. In another type, the dorso-ventral, the fibers run at right angles to the frontal plane. In the holostome cercaria (Fig. 54) no such series is found, al tho the longitudinal series is so arranged that the fibers are on eage and might be taken for the dorso-ventral series. The view of Bettenciorf (1897:315,316) that the "Epithelzelzen" of BIcchmans are really longitudinal muscles, can not be considered valid, since the former are indifferent to stains and the latter are descly st ined by the same methods of technic. 

In the oral and acetabular suckers and frequently in the pharynx there exist the transverse, longltudinal and oblique series, Interwoven into an insecarable complex. These are best jevelofed in the Ampistomata. In view of tie fact that the redia which produces germ balls is an adult and the cercaria is an inmature individial, it is not surprising that the pharynx of the redi-is ficrous, with few nuclei and large vacuoles, wile the charynx and suckers of the cercaria are composea of cells practically undifferentiated. In the rediae the fioers can be traced to the myoblasts. The main deeply seated system of muscles for tire cercaria consists of the muscle band series of the digestive tract. In the holostome (Fin. 54) an aditicnal muscular activity has been assumed by the cirrus pouch. Aside from these no muscles are developed in connection with the genitalia in the larva. As regards the digestive tract, the cecd are covered with an outer and an inner series. The former are longitudinal fibers and the latter are circular fibers. This is in harmony with the muscular layer studies made on cther Platyhelminthes.

Histology of the muscle cells. An important steg was made in the knowleage of the intimate structure of the trematode muscle cell when Bettenciorf (1897) showea the connection between the muscle fibers and tre myoblasts. The present study corroborates Bettendorf's work. The nuclei of the myoblasts are oval. (Figs. 118,119). The cells very early send out long prctcplasmic strands along well defined paths. While the processes from the myoblasts may energe from any part of the call, the longitudinal strancis are always directed in a longltudinal lane, and tre circular fibers are always circuiar. Aunique picture is presented at the point where the furcae of the aigestive tract arise (Fig.118). 

Here there are two anterior processes runing cephalad, and three strands proceeding caudad along each cecum. The chromatin in the nucleus of the myoblast is usually confined to the karyosome. 



\section{Armature of the Trematode}

The miracidium and sporocysts are not provided with hooks or piercing armature. The redia is usualiy conspicuous because of 1to oral sucker, pharynx an- gut, and not because of any armature. In the cercaria, hovever, are found, even in the most delicate species, spines covering the tunica enciogena, especially in the region of the head. In the special group of the stylet cercaria the stylet is the larval organ which is of specific systematic mork.

It is not a universal rule, however, that all redia and sporocysts are unarmea. At times a modification of the posterior

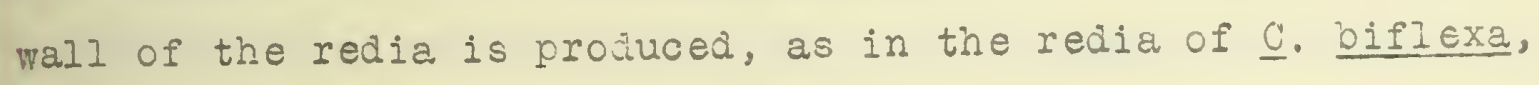
where the terminal organ is spinose(Fig. 141). Leiper and Atkinson (1915:202) found tine secona sporocyst generation of Schistosoma japonicum to be covered with a spinous integument. Nore conspicuous is the prepharynx organ of the redia of cercaria pellucida (Fig. 7). This organ is four-lobed, and has on the outer side of each lobe long spines projecting forward and small spines directed laterad. The use of such a weapon within the soft parts of the host tissue produces untold injury.

No armature has been observed on the body of any moriostume cercaria. The holostome, Ietracotyle nicientis (Fiz. 47), has a spinose covering over the entire body and special spines in the region of the acetabulum and accessory suctorial grooves. Spinose modifications are common in the distome groux, and in some cercariae, setiferous modifications of the tail. The types winch the writer has examined have the armature confinei exclusively to the body. These integumentary differentiations will be discussed 

under the headings of 1) general bodily spinosity, a) spinosity of the oral aperture, 3) the hood spines of the echinostomes, and 4) the stylet organ of the xiphiolocercariae. In aduitiun ti.ere are the spines at the posterior end of the trunk in the caudal fockets. Their locomotor function has allowed of their consideration in another plac.

In many cercariae there is a tendency for the entire bodily integument to become modified so that the surface iairly bristles with needle-like spines. These are usually arranged in a regular diamond pattern, and are more fully develpped at the arterior end of the body than in the caual portion. A fair conception of tris tyce may be gotten from figure 90 . This conaition is found ir some xiphidiocercariae and some echinostomes. The spines are always pointed forward. The only differentiation consists of a more marked development forward.

Of a somewhat more limited distribution is the oral armature of spines in the schistosomia, ‥ gracillima (Fig. 142). These spines are turned into the body with the inpocketing of the oral sucker-pouch, so that the animal in the conition of contraction appears perfectly aspinose except for the arrature of the acetabulum. But on protrusion the oral sucker is cromed with a solid cap of spines.

dore specialized and specifically valuable in systematic work is the hood of spines of the echinostome group. Ihis collar is usually an incomplete ring, consisting of a circlet around the dorsal side, extending ventrad into the midale half of the body. Dietz (1910) has seen fit to sketch 63 figures of spine characters and numbers in his monograph on the Echinostomidas of biras. The 

adult echinostomes of North Anerica have recelved little attention and in consequence a descrintion of the specific spine characters of the cercarlae will be of little value until more attention is Elven to the acults of the family.

The stylet is the unique larval organ of the xiphidiocercariae. Because of its resemblance to a quill, it might be nore properly called a quill than a stylet, for 1 ts value as an organ of piercing is questionable on account of its frallty and frequently disadvantageous leverage. It is a mooid structure, situated in the dorsal wall of the oral pocket, well supplied with ruscles to work It in any airection anteriad and laterad. It is fully formed only In the mature cercaria, and is cerried into the cyst (Figs. 84,85). cuite generally the stylet is recognized as of specific systematic value and is so figured in systematic descripions (Luhe, IJ09: 189-200), but the stylets as figured are so non-specific as to be cf little value in the identification of species. The writer believes that the stylet is of specific value, but this specificity lies in the details of the organ rather than in the general outline, and the details must oe ifigured to be of value. (See figs. 5r,61, $77,83,81,102)$.

l'he stylet is usually a weak organ mechanically and coorly levered. It is, however, resistent to chemicals and indifferent to ayes. Fine stylet of Cercaria glandulosa is extremely delicate, so that it goes tc pieces imrediately when a cover glass 1 s presseit down on a water mount of the worm. The stylet, as a rule, is hard to observe in preserved mounts. 

The Glands of the Agaric Irematoue

Glanduiar organs in the trematode may be distinguished as dermal, sulivary, mucin, cystogenous, genital ans locomotor. me dermal glands are those imbedaed in the subciemal tissues, are unicellular, usually flask-shaped, with a small auct ocening to the exterior. The salivary glands incluae all of the unicellular glancis which open into the digestive tube. Mucin glands are paired rieht and left groups of one to several gland cells emptying into the oral pocket thru long attenuate ducts. S'ince mucin is a constituent of salivary glands, these glands are to be considered as a modified salivary gland. Cystogenous glands are imbeuted in the parenchyma and are usudly fillea with rhabaitiform granules which superficially resemble rice grains. They are not to be confused with the dermal rhabdites of the Turbellaria. The cystogenous glands function in the formation of the larval cyst at the time when the transfer to the definitive host is to be made. Genital glands, in the sense defined here, include only the auxiliary gland elaments of the genital system and do not refer to the sex glands themselves. Locomotor glands arise in connection with the locomotor organs in the posterior part of the body.

Ihe dermal glands are of adult significance. Looss (1894:125) has founs them in all groups of adult trematodes studied, out does not record them for any cercariae except . vivax sons. (1. C.244), (1896: 219, fig. 176, glcu). No dermal glands have been found by the writer in the course of the present study.

Salivary glands are probably present in all groups of cercariae and in some rediae. In the simplest form they are nothing more than pyriform cells in the region of the digestive tube. Thus 

the monostome cercaria, $\underline{C}$. Irbricata, descrived by Louss (15ij:195) as having a charynx without a bulb, has unicollular rands massel around the tube in the pharymx region. The furcocercariae, with no true pharynx, have a similar grour of cells in the pharynx region, 80 closely massed together as to lead Locss into error in considering them a true phorynx (1896: 230, fig. 176 ph). As a matter of fact, the structure of these masses of glands in the furcacercariae does look superficially like a pharynx (Fig. 14a), but on cross-section the cells of the complex are fumb to be unmistukaioly glansular (Fiz. 152).

A modification of the type of salivary gland just descrioed

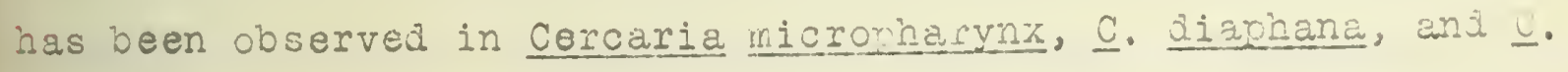
glanduiosa. In thses species the carcariae show not only the muscular pharynx, lut also a large groun of glana cells around the aigestive tract. In $\underline{\mathrm{C}}$. micropharynx (Fig. 93) the gianas arc preharyngeal, grouped in a spherical mass around the oral chamber. They are minute cells, about 3 u in trans-section. The glands of C. ilachana (Fig. 7o) exhibit a maximum Elandular growth in the visinity of the pharynx proper. Several hundred gland cells about $3 \mathrm{u}$ in alameter surround the nharynx. A case of secretion along the entire digestive tract is found in C. glandulosa (Fig. 60). In this species the glands are much larger than in the two preceding species about $6 u$ in cross section and Izu to $25 u$ in $l e n g t h$. They are formes along the entire course of the lumen, from the orifice to the blind end of the ceca, al tho they are best developed. in the region of the pharynx.

A distinctly different type of gland is that terned the "stylet gland". It is so-names because of its frequent occurrence coincidently with the stylet organ of the xiphidiocercariae. But 

since 1t occurs, too, in furcocercarias and in echinostome cercariae, where there is no trace of a stylet, the evidence supports the view that this type of gland is more generalized and more prinitive than the stylet organ.

Ihese mucin glands, for such they are, are found in the cercariae of the distome groups examined by the writer, and in the redia of the holostom, ‥ flabelliformis. They are bilaterally synmetrical, Iying outside the intestinal furcae, behind the region of the pharynx. They open thru long-necked ducts into the oral pocket. The glands are in masses; they vary in the number of cells from four in each lateral mass of the furcocercariae (Fig. 144), to eight or ten in the stylet cercariae, while in the echinostones they run as high as 110 on each sile of the esophagus (Fig. 134). the cells are, in general, characterized by a densely staining granular protoplasm and a highly refractive nucleus, which renains hyaline when treated with haematoxylin dyes. Most interesting is the type presented in tne stylet group, especially tine form Cercaria crenata (Fig. 55), where there is a differentiation of inner and outer groups of the glands on each side of the gut. These groups have inaividual canals to their exit at the oral pocket. The outer series consists of six glanas, comparatively small, $8 u$ to $9 u$ in diameter, goblet-shaped, extenaing caukad to the midacetabular region. They are finely granular and are best studied in living mounts. The inner series consists of five cells, two of which are situated just behind the pharynx and the other three postacetabular, thus causing the inner series to be divided into an anterior and a posterior group. These inner gland cells are Ilu to $15 u$ in diameter, and coarsely granular. Their difference 

In structure suggests a functional difforence.

The muoin glands of the redia of $\underline{\mathrm{C}}$. flabelilforwis are paired structures, lateral and dorsal to the digestive couch, consisting of a single series of six cells wich oxen thru a comon tube into the pharynx region of the redia. The cells are similar in structure to the mucin cells of the cercariae of other groups, altho no such jlands have been recorded from the cercariae of the holostume group. Only one other case has been reportes for the redia, that for the parthenita of cercaria equitator by ssinitzin 11911:52, fig. 50). In this redia tine gland cells consist of a single cell with a wide duct to the pharynx region. A similar pair of unicellular salivary glands is flgured by Looss for the miracidium of Schistosoma haematobium (1896: fig. $113 \mathrm{glcch}$ ). This occurrence of the mucin glands in the miracidium, redia, and cercaria of various groups, and the fact that they pass into the intermediate host along with the cercaria (Ia Rue, IS17), show that these organs are of fundamental importance in the economy of the worn. lhat these glands are of more specific character than tine ordinary salivary and epiciemal cells of the trematoaes is denonstrated by their differential staining reaction. The usual haematoxylin ayes show a great number of granular protein inclusions. Recently (La Rue, I917) it has been shom that these glands in Cercaria marcianae have mucin in their aucts, becauss of the staining reaction with toluidin blue and thionin. La Rue suggests that the glands produce "mucus", in view of their specific staining reacticn. However, since the glycoprotein of salivary aigestion is mucin (Wathers, 1915: 323), it is more exact to designate these glands as mucin glands. 

A type of glanj unuoubteily common to 211 cercariae is the cystogenous gland. It is a unicellular organ in the parenchyma just beneath the integument. In some groups these cells may be small and scattered between the cells of the parenchyma (C. I Ianzulosa, fig. 62). In other groups the gland cells are very large and conspicuous so that they fill the greater part of thebody,as in the species, ‥ coliucida (Fig. 14), C. Lenjritica (Fig. 85), and C. trisolenata (Fig. 132). Whe material within the cyst cells is usually milky, semiocaque, either homogeneous or granular. In most cases the contents consist for the most part of the rhabaitiform granules, which are indifferent to syes. mise granules are not attacked by weak acids or alkalies, but are digested by strong acids or bases. It seems probable that they are of a derived protein nature.

The formation of the cyst varies in the tyoes studied. In the majority of the species the cyst is a firm envelope with a free space around the enbryo, more or less filled with a watery fluid (Figs. 41,84,118). On the other hand, some of the cysts are more mucoid in structure, with a granular viscous inner portion and an outer jell (Fig. II).

The methods of encystment differ, In the monostome where the encystment is rapid and an entire lot of mature cercarias encyst in tmo or three minutes after they are freed from the redia, the process is so rapid that the tail is not entirely cut off until the major portion of the cyst is formad (Figs. 9-1I). Where the time of encystment is considerably longer, as in $\underline{\mathrm{C}}$. trisolenata and $\underline{C}$. dendritica, the tail is discarded long befure the crucess of encystment actually begins. The encystrant is an alaptation 

on the fart of the larva to the change in environacnt. In tro cases, however, encystment takes place within the liver of the primary rost (‥ nicropharynx and $\underline{\mathrm{C}}$. biflexa). It is hichly frobable that in these cases encystment was the result of temperature stimuli, since they were secured in November when the inter hac alreay set in. Here, then, encystment is apparently an awaptation to "wintering over".

In only one group has there been no record of encystment of the cercaria. This group is that of the furcocercariae. Here the tail is aropeci only under the pressure of the cover slip cr wien the worm begins to disintegrate. The statement of La Valette (1855: 34) is a gcod expression of the conjitions in this group of larvae:"Cercariae cystibus non indutae in aniualium vertebratorum intestinis pereunt."

The phenomenon of encystment is one which has been observed by many investigators. It has been show and describen very accurately by La Valette (1.c.), Moulinie (1853), Pagenstecier (1857), and a long line of later investigators. Wuminie refers tu tio studies of earlier workers on encystment, mentioning v. Siebola (1835) and Steenstrup (184z). The crejit for the first record of encystment unioubteoly belongs to Nitzsch (1807). Nine years later this witer his reccrded his observations cr the encystment of Cercaria ephemera. The review in Isis (1818: ra8) describes the process of decaudation and encystment as observed by Nitzsch, and shows that this worker expected the cyst to develop the following year. Fantham's criticism of ivitzsch is essentially unjust (1916: 12), since Nitzsch consideres the cyst to be dorrant and not dead. The process of encystment has ceen jescribed in detail by 

Iromas in his work on Fascicla hecatica (ISE3:129). Incystnent here conforms to the rapid type, described for the morostone C. peliucica. "mise tail is sometimes shaken oif before encystmert be ins, but, as a ruls, the tail remains in connection with the boiy during the process, ani continues to be energetically lashed from siae to side, until finally a more vigorous movement detaches iu. whe whole process is very rapid, and in a few minutes a layer cf consiârole thickress is formea, whilst its subsiance jebils to haroen."

Locss (1895) has describsd the cystogenous glands in murnerous species of cercariae. Ssinitzir (1905) hac found the cystogenous glands in the vicinity of the excretory cesicle of - macrcoerca, and has intempeted them as lying within the bladuer, kut this seems improbable. 

Of the four most inportant systems cf the trematoule the excretcry system is the most delicate. It can be worked out with precision in the living animal, but in preserved material it is next to impossible to find more than the main trunks of the system. In $a l i$ of the cercariae and parthenitae the excretory systems describel here have been stuaied from living material. Altho there we many individual differences within groucs, yet the fundamental constancy is evident.

The Monostonata. The main features of the excretory system of all of the Monostomata are the same. The cercariac have two main trunks arising from a common point just behind the median eyespot or median pigment center, and proceed posteriad and laterad to the posterior part of the boiy, where they foin ons another in the common vesicle. The blazider cpens to tho outside corsad thru the excretory pore.

Ihe main excretory trunks are fliled with large refractory granules, nore extensively describei on p. . The continuous circuit of the system rrovides for the transfer of granules and other waste products from right to left and revisely, depenjent on the contraction and excansion of the several carts of the animal. The blaijers of the various species differ considsrably insize and structure, but as a whole they may be placed into two sub-groups wich are of considerable systematic value. In the trioculate forms, such as Cercaria pellucida, in dorsal view the bladder is distinctly trilateral when relaxex, with the exoretory pore median posterior. This same tyce is found in C. eohemera witzsch (ssinitzin, 1905:fig. 76), and in C. imbricata Locss (1985:fig. 148), and also for $\underline{C}$. zostera Ssinitzin (1911: Tav.I,figs. Is,15). 

In action, however, due to the muscular moverients of the fosterior portion of the buly, tise anteriur portion of the blawer aay sem to be a separate organ, opening into tho bulbous zosterior portion of the vesicle thru a constricted area. In the bioculate tyces, on the other hand, the bladder is spherical vesicular, with. the excretcry trunks emptying into the extrene lateral reaches of the vesicle. The excretory pore in these species is suioteminal rather than terminal. The only bioculate species known are $\underline{0} . \underline{10}$. ocelca (ie Filiffi, 1857:ol.I,fig.3), ‥ urbanensis (cont, 1ElE: fig. 5), and $\mathrm{C}$. konadensis. Lebour (1s07: 443,pl.X,fig.E) describes the bledder of $\underline{C}$. Ionhocerca as semilunar, but from her figure it eppers more reniform tian lunar. Cont does not describe the shape of the bladier of $\underline{C}$. urbarensis, or state its size. The miter has Iound it to measure $50 u$ to bu in median sagittal I ins and 60u in transverse section. The excretory pore of the species is large, some $20 u$ in dicmeter; it is weakly muscular (Fiz. 35). In $\underline{\text { c }}$ konacensis (Fig. 29) the oladier is small, Isu to lou ir diarecer. The excretory pore is corresponingly small, 3u to $4 u$ in aiameter, and weakly muscular.

The excretory system in the tail uf musustomes is jiraje. It consists of a median tubule, with tributary laterals, wich swell in the proximal region and empty into the comron blaxier of the trunk Holostonata. The excretory systems of Hemistomidas and Holostomidae are sufficiently different to require separate treatment.

Folostome type. No accurate or detailes aescription of the tetracotyle type of excretcry system exists. deFilipoi (1857: fis 26) ias pictured two laterals for $\underline{c}$. vesiculcse, arising from num- 

erous tubules in the anterior part of the boù. The connection of these tubes is not clear in the region of the bladuer. Altho the sketch was mede "to sho:7 farticularly the laterul vessels", $1 t$ Sives no adequate concextion of the fundaments of the system. Erandes (IEGI:5S9) is satisfied with the statement that the "system reaches into all parts of the cone; an especially lares caral rasses longitudinally thru the anterior wal of tre cone." Only a faint suggestion of the system is figured by Hosseter for Holostonum excisum (Iinstcw) (1909: fig. 17). In vicw of the lack of definite data concerning the excretory vessels of the holostomid group, it seems advisable to describe the system in considerable ùtail.

The excretcry-vascular system of Cercaria flebelliformis is shom in figure 30. At the extrsme posterior end of the wom. situated slifhtiy dorsa, is the excretory pore. It is the openirg if a relatively small bladder, lalger in no aiameter than the pore itself. At its antero-lateral horns two large trunks arise, considerably inflated in their posterior portion. They may be traced forvard along the inner reaches of the digestive ceca until they reach a place about time-fifths the aistance from the anterior end of the larva. Here a transverse canal is found, with a median connection between the two trunks, and lateral transverse tuoules. The lateral tubuIes are concerned with the part of the larva posterior and lateral to them. Between them and the nain longltulinal trunks are found a great number of anastomoses. Antericr to the median transverse canal the tubules spread out in fan-like arrangement, running to the sides and front of the worm. Undoubtealy this system was originally distome in character. 

It was made over to suit the needs of a modified alstome larva. Ine longitudinals are clearly those of the $Y$ type so ccmmon to the excretory system of the distomes. On the other hand, the transverse tubes and the anastomoses of the postero-lateral reaches wre nev structires.

The entire system is flilei with minute refructcry granules which facilitate the tracing of the courses of the var1ous veseels. Hemistome type. This type has been worked out in faithful detail both in the larva (Diplostomulun) and in the adult. A discussion of the excretory system of $\underline{C}$. ntychocheilus will be Iimited to the points of divergence from the previously described speciss.

The earliest larvae of this group to be accurately figured are Diplostomulum clavatum (ijordinann) and D. volvens (ivordiann) (1832: Taf. II-IV). From the elongated bladoer there arises a bicornuate structure which proceeds forward and outward for a short distance. A bifurcation of each cornu then takes place, so that there are two pairs of vessels to proceed forward, an inner and a $n$ outer pair. They run forwara to a plane in front of the middle of the body, where they unite and run cephalad as a single vessel. A transverse vessel is found posterior to this union; this vessel connects the two sides of the system. Brandes diagram for the excretory system of D. abbreviatum (1891:Taf. 39,fig.17) differs from this type only in the details and not in the main features.

The system of Cercaria otychocheilus (Fig. 49 ) is not Iundamentally difierent from the above describea systems, but has 

interesting modifications. $\Lambda$ long, attenuate non-muscular bladder 1 ies dorsal to the posterior genital asparatus. It does not pair but gives off a single median longltudinal vessel, which proceeds forward to the midacetabular region, where it gives off the transverse vessel. Ihe median longitudinal trunk then runs forward to the origin of the ceca. Here it gives rise to three antero-lateral vessels. These bend outward and backward, with numerous anastomoses, and finally unite with the lateral traces of the transverse vessel. The outer reaches of the transverse vessel give rise to many anastomoses which are conspicuous in the postero-lateral portion of the body.

The fundamental vessels of the holostome type are the paired. laterals and the trarsverse vessel. nnastonoses ani molificatiuns have altered the system appreciably, but not beyond the ability to recognize the common type underlying the system in all of the species.

Ihe entire system contains many meaiur-sizec refractory granules which oscillate back and forth thru the vessels at every movement of the animal. By unusual contraction of the worm, the granules are fcrced into the bladjer and out thru the excretory pore.

Distomata. The distome cercaria has a simple tyce of excretory system, different in sub-groups, but retaining the funuamental structure of the group as a whole. This plan consists of a posterior median bladde with two lateral longituinal vessels in the body of the cercaria and a median longitudinal vessel in the tail.

The xichidiocercarias. The excretory system of the stylet cercariae consists of a blatier, usually muscular, ant a pair of lateral longitudinal vessels wich arise from lateral corria cf tho 

bladier. The Erimitive lateral system consists of tirec tubules, which arise from the comin on lateral son after the latter lewves the biaijer. Ine of these trivules Frocesds restariad, while the other two run forward as inner and outer tubules. The single reilan tail vessel ands olinuly near the posterior end if the tail; it scmetires receives tributaries, but this is not ulays tine case.

l'he bladier is a modian posterior structure ocening to the extarior thru the dorsal core. It is usully muscular, unoared. It varies greatIy as to size and shape. It may be pyriform (Fig.90), obovate (Fig. 93), crenate (Figs. 55,81), truncate or cbtruncate (Figs, 60,100), falciform (Looss,1890: fig. It6), or lunar (Looso, 1890: : ig. 179).

line physiological ani morphological bladiers are not al wajs the same. The former may encroach on the Iateral systems in order to increase its capacity. Mhis encroachment may consist of mere enlargenents of the cornua without any change in structure (C. olandulosa, Iig. 60; C. micropharynx, fig. 9o). on the other hand the neads for a muscuiar enlargenent sometimes cause the muscularization of the cornua (c. dendritica, fig. 81; c. crenata, Iig. 55;

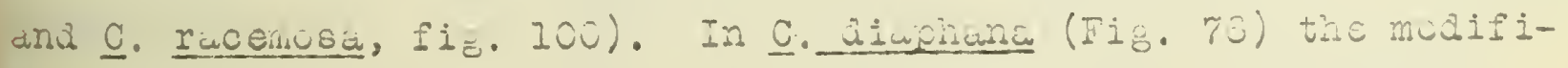
cation of structure has taken place before the enlarge ment of the long median vessel and the lateral tubes.

The capiliaries trioutary to the lateral tubules are represented in their most simple form in C. micropharynx (I.c.supra). However, the internal anterior vessel nay move forward, as in C. crenata, or become rulimentary, as in $\underline{C}$. glaniulosa. The external anterior tuivule is usvally the most filly developed.

It is important to note that the lateral systems of the 

xirhidiocercuriae never anastomose or co:zesce in any way. It.e mel1an sag1ttal plane acts as a "watershed", eltho the larva is not appreciably thicker in that plane than farther laterak.

In the forms studied there were found no large flame cells 112 the courso of the excretory system. If any minute flame cells ware present they were ooncealed by the thick integunent.

the literature shows a paucity of observutions on the flame cells of larval and adult distoms. For Gorgordera pagenstecieri and for Philodistomum folium Ssinitzin (1905) shows the details of the flane oello. They consist uf dis awolu cytopiasm in midich is imbedaed a spherlod nucleus with rich chromatic inclusions. This cell is the terminus of the capillary (cl). It is ordinarily funrel-shaped, but vihen distendad becomes deeply reniform. The junction of the flame cell and the capillary is markea by a considerable number of cilis wich viorate rythmicelly, giving rise to Ssinitzin's characterization, "vioratile tip cell of the excretory syster. 18

A much more detailed study of the flame cell of the adult distome is given by Looss (1896: 110; figs. 72,77) for Distomum sanguineum Scns. The details of the cell per se are not appreciably different from those given by Ssinitzin, out the distribution of the flame cells thru the body of the distome is of interest. There are four symmetrical pairs of groups of three cells each in the middle of the body, and cne pair of two cells each in the anterior and posterior reaches of the boly. making sixtesn paixs of fiame cells and tubules in all (Fig. mr). This gives some idea of the arrangement of the flare cels in the tyolcal distome. In Distomum isoporum(Looss, 1894: fig. 103) six paired groups of ul- 

timate tubulos are figured with four flane cells to each group, making forty-oight flame cells in all. In Distomum cyliniraceum (1.c. fig. 163) there are six paired groups of capillaries with three flame cells to each group, totalling thirty-six flame cells. Thus the number of flame cells is not constant in different species but remains constant, of course, for each species.

Looss (1894: 249,250; 11g. 186) suggests that the fundamental larval system is the fundamental system of the adult. Extension and modification occur thru a dichotomy of theoxisting capillaries and flame cells, and an encroachment of the tubules upon the capiliar ies. The greatest modification takes place during encystment, altho this is in no sense a metamorphosis.

Among adult American distomes the excretory systam of Microphallus opacus (ward) alone has been worke. out with the exactitude and finesse of the European workers (wrigt, 1912: pl.17,figs.1,2). This form has the aistome Y-shapea bladder and cormu. There are only eight paired capillaries, and only sixteen flame cells. This condition constitutes a remarkable reduction of flame cells from the ordinary types, a reduction which can not be entirely accounted Ior by the small size of the species.

The Echinostome type. This family of distomes is characterized by simplicity of detail in the excretory system except in the region of the head. The bladaer is not markejly muscular. The pair of lateral vessels arises from the anterior median region of the bladder, and not from the horns of this vesicle as in the xiphidiocercariae. The main trunks do not dividebut proceed to the cephalic extremity along the lateral margins. They sometimes receive small tributaries along their course. In the cephalic region the vessel 

colnonly flexes brok on itself. Such flesurc may c ntinue back to the postarior extremity of the body, as in . fig. 43), or may continue caudas only a short distance, reflexing a second time (‥ biflexa, fig. 135). An intermeiiate furm, $\underline{\text { C. }}$ ecidisatum, fas baen iascribei by Luuss (1894:1EI), whore the first flexure continues caudad while another part is reflexed ceplalad.

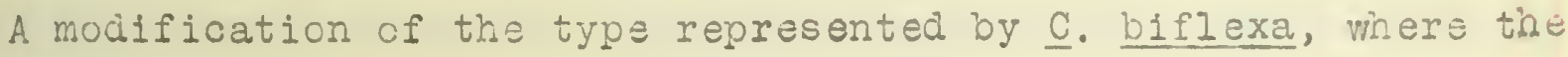
the doubel flexure is entirely within tine cechalic region, is seen in C. trisolenata (Fig. 109). Either the end of the flexure has been fused to the most anterior part of the main vessel, or the midde portion of the system has been modified. As a result a triangular channel system has been formed at the anterior end of this excretory system.

The most characteristic feature of the two species of echinostome exoretory system studied is the triplet of flame celis at the anterior part of the system. A detailed study of the flame cells in $\underline{\mathrm{C}}$. biflexa is found in figure 138. The cells are situsted in the pockets communicating with the uitimate part of the reflexed tubule. Cell a is found in the sinus between the secondary and tertiary vessel. It points upward and outward. It is the smallest of the three cells. Cell c cccupies the smollen end of the tertiary vessel. It is the largest of tine three vessels; its cilia are the most rythmical of the group. Cell b lies midnay between celis a and $\underline{c}$. It points dowward and inward. Cells $\underline{c}$ and O function in bringing the excretory wastes into the vassel from tiae surrounding tissue and cell c directs the excretory material along the vessel.

The excretory system of certain species of echinostore cercarias 

gontain granules. These granules have been fuund in all C. trisolenata examined; they are found in the lateral vessels from th refion of the pharynx pisteriad to tine acetabulum. Lhey have rot been sear in $\underline{\mathrm{C}}$. biflexa.

- ie excretory system in the tail of echinostome cercariae is

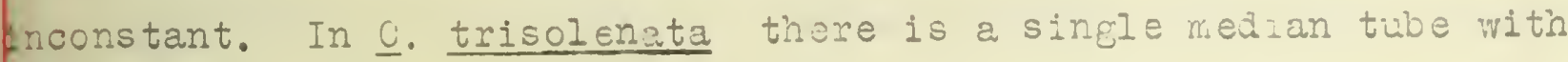

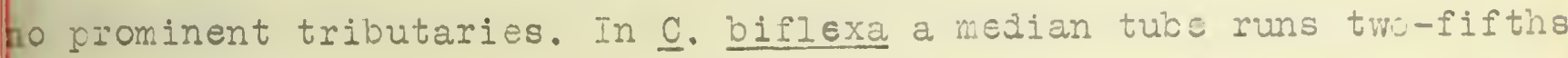
the distance posterial, winere it divides to form two tubules which proceed distad. In $\underline{\text {. trivolvis and }}$. reflexas (cort, ISIs: figs. $(9,43)$ the redian vessel of the tail courses backward about one-fifth hy aris onvis these in a iffurcation, the cris uf which oren to the ides. The biflexa type sems to be intemeinate betwecn the echinostome type described by Cort ani the more comon distome type. It is Eighly probable that the excretory systen of the echinostome, with three fiame cells in the anterior portion of the system and possibly overal smaller ones farther caudad, has arisen from tine primitive Histome type. In most cases, the fosterior flame cells have become iused into largs ones, so that only three flame cells remain in the anterior part of the system in $\underline{C}$. trisolenata and $\underline{\text {. biflexa. }}$ The Furcocercariae type. The furcocercous type of Iarva has, on the one hand, comon fundamental features of the excretory systam, and, on the other hand, highly variable featurss.

The mature apharyngeal aistone cercaria of the furcocercous type has a very small bladder in the posterior fatt of the body and two lateral vessels runing cephalad. The uniaired portion of the tail has a single median canal, which is united to the system of the trunk thru an "eyelet anastcmosis". The median tubule of the tail forks to enter the rami. The oriein ci the caulal vessels has 



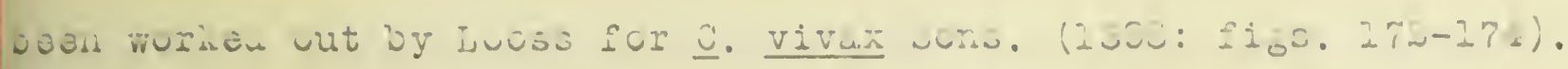
Whey arise as the rosterior extenaton of the paired boiy cxcretury tubes. Their fusion in the common portion of the tali occurs after the rami have become well differentiatel. The "eyelet" is an inuex of the original faired system in both body and tall.

A stuciy of the species . gracilina (Fig. 145) ard - tuberistoma (Fig. 155) shows the main features of the vivax type. The grall bladien, the lateral canais, the median caudal tube, bifurcatIng distally to proceed into the rami, the "eyelet" at the juncticn of the boly ant the tail, - all of these seem to be constant for the entire group. Beyond these characters the features of the several species are divergent.

In C. gracillima (Figs. 143,145) the caudal porticn is extremely simple, containing only the common median tubule and the

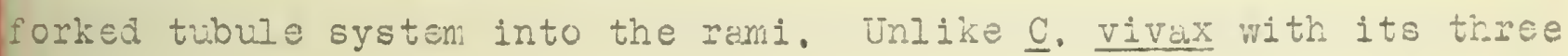
pairs of flame cilia in the comron caudal tubule, this species has no flame cells in the cautal portion cf the rom. The system in the body of the cercaria has a non-muscular trilateral bladder, small posterior tubes arising from the lateral tubes, and a ciliary pocket about one-fcurth way from the posterior marein of the bouy, on the inner wall of each lateral tube (Fig. 145). At the costerior morgin of this ciliary pocket small tributary carals from the median plane flow into the main canal. Slightly cephalad is anotrer pockst, somewhat larger than the ciliary pooket, filled with small granules of various sizes and shapes. Into this pocket four or five small small canals empty, the median ones of which anastomose with their Hates from the opposite side. ivo ciliary cells are found in the terminations of the caciliaries. 



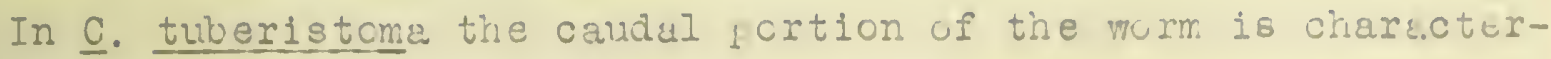
1.eu by five trinsverse canals. Another fair, arterior to those, is conspicucus because it runs forwar for a short distance and Is then reflexed backward for sone distance (H18. 155). The eyelet and the bladzer are hoth muschlar are both musculer. In the body portion there are no jockets for the lodgenent of granules and no transverse anastomoses. No flane cells have been found in this larve.

A comparison of the furcccercous larvae with the Ecisistoscmidae shows the striking similarity of the excretory systems of these two groups, previcusly considered separate groups. Looss (1895) firds the system of male and fara Schistosoma haematchium alike, al tho that of the female myy be slightiy better developed, due to a minimization of the musculature. The blador is median, non-muscular, except for a weak spincter at the pore. It receives the tro longitudinals at its antero-lateral reaches. There is no median canal (I.c. 72). Many of the laterals are dendritic, altho they do not anastomose. Small flame cilia are at the heads of the capillary tubes of $3 u$ to $4 u$ dianeter. These flane cells and capillaries are intra-cellular, and not surrounded by an epithelial Iining.

Excretory system of the Parthenitae. We are dependent on the observations of Louss fur the true functional excretory system of parthenitae (1892: 158-16I). The system elaborated by Ssinitzin (1911: 77-80;Tav.I, figs. 24,25 ), in connection with the birthcore of the reaia, the "protonephrisia", hus not proved to be of excretory function.

According to Looss (I.c.) the excretory system both in the sporocyst and redia arises as a paired structure, from which 

caplliaries and flame cells soon arise. The observations of the writer have been confined to the adult scorocyst and redia cf the species stualed, in wich the system is strikingly different from the embryonic condition. In many cases the excretoly system consists of a diamond pattern of intercellular channels, without any clue to the former bilateral symetry. The same amount of modification holds for both sporcoyst and reila. In the holostome redia (Fig. 4a) this diamond pattern is found. No flame cells have been fcund in adult parthenitae. This distinct modification of the excretory system in parthenitae is not surprising in view of the extraordinary modification of the animal that has resulted from its endoparasitic habits during its antire life.

Excretory granules. The excretory granules of the ccrcaria and parthenita are spheriodal and have the general appearance of glass beads. Their refractive index is very high. The size of the concretions is variable in aifferent groups and even in the same individual. As a rule the granules are largest in the monostomes and holcstomes.

Few writers have given consideration to these excretcry granuies. Thomas (1883: 117) says for Fasciola hepatica larvae that "the yelicwish granules..... appear to be excretory products formed winin the cellaof the sporocyst and then ejected. They are partially soluble in acias, Ieaving an organic basis." Looss refers to them as "opaque concrement-granules which on first sight throw the bouniaries of the tubules into black relief"(1894:105). They ar irsoluble in alcohol ani color beautifully in stained mounts. Feference is made to these granules by cort (1915:16) to the effect tinat the tubules of the monostomes are filled thruout their entire length 

"With small round concretions which dieappear in the prucess of preservation." sied witer has found that thase oranulce are not isually preserved in the corrosive-acetic fixing fluids. However, if Iixation is done without the acid fraction of the fluid the ranules are preserved. Acplication of strone acid to the granules causes an evoluticn of gas. The granules are negative to inorganic $\mathrm{CO}_{2}$ tests, and are non-crystalline, as determined by the petrographic microscope. They take haematoxylin stains readily, al tho they do not stain deeply. They give no Molisch reaction. The xanthroproteic test is positive, indicating a benzene nucleus. It is probable that they consist of a conjugate protein before fixation. Fixation with mercuric chloria alters them, since they are then acid and alkall resistent.

Generalizations on the excretory system. The excretory system of the trematcdes, including both cercariae and parthenitae, is essentially a bilateral system. It arises as tro paired tubules, which fuse in the bladaer region of the crearia to form the vesicle. The mature system of the parthenitas is highly modified from the primitive type. The trend of the modificatione is not directed. The system as found in the cercaria is carried into the adult. Wost individuals of all generations contain within their excretory systems spheroidal concretions, which are waste organic products, quite probably derived proteins. They lodge in the main tubes and are expelled thru the excretory pore. 



\section{The Genitalia}

This system of organs has been the most constant basis of clasification of adult trematodes. A more delicate technic is required for differation of the genital organs in the cercaria than in the adult worm. Because trese organs have failed to come wt in the orainary preparations, no attempts have been maje to use these organs as a basis for correlating larvae and adults. cell masses have been figured by Looss (1896), Ssinitzin (1905, 1911 and Cort (1915), but trese workers have not in any case show them in letail. Dy means of a lanzthy staining in a weak solution of Delafield's haematoxylin, followed by rapid differentiation and then neutralization with potassium acetate solutions in the higher alcohols, the genitalia of the cercariae have been traced with a degree of detail not previously attempted. These or jars have been found to offer valuable data for correlating cercariae and adult trematodes.

\section{Monostomata.}

All three species of monostomes on which observations have been made, Cercaria cellucida, C. konadensis, anj . urbanensis Cort, probably belong to the Notocotylidae, characterized by tre symutrically arranged testes, the presence of Iaurer's canal, the Iocation of the vitelline glands in a couble series on each side of the body, and the courses of the uterus ënd vas deferens. Ssinitzin (1905: fiz. 76) shows the inner series of five paired vitellaria for $\mathrm{C}$. echemera Witzsch, but he has figured no outer series of three glands, such as are found in the three species workea out by the writer. Ssinitzin is in error in cunsilering them cystogenous glands, because their connection is traceable thru filiform 

Sucts to the ootype. Plth the growth of the cercaria to tie adult nonustome the originally aistinct and readily recogrizable vitelline elements bccomed fused in part. Looss's fijure of lotocotylp verrucosa (Froel.) (1895: fig. 94) shows five rather poirly lefinea focl of vitelline elements in each of the lateral series. It 18 cossible that the five inner elements of the series have become fused to the three outer elements of the series, thus causing the indefinite outline of the elements in th adult worm. Ihe vitelline glands of Notocotyle quincueseriale are arcarently eigh to the side. Here the three glands of the outer series may have been introauced between the five glancis of the inyer series (Barker and Laughiin, 1911: pl.I, fig. 10). A symetrical pair of viteline ducts, between the inner and outer series of glanàs, is the conduit of the glandular elements to the region of the ootype.

The cercariae of this group that the writer has studied are readily differentiated by a comparison of the genitalia.

In Cercaria Eeiluciza the weli-leveloyed cirrus pouch and the poorly developed vagina, reach the confines of the excretory trunk just behind the median eye. In $\underline{C}$. konadensis the cirrus pouch and the vagina are both equally developed. The former is falciform, the latter pyriform. The vagina is lateral to the cirrus pouch but is somewhat posterior to it. The genital pore in U. pellucida is not as far posterior as that in $\underline{C}$. konadensis. In this species, as well as in $\underline{C}$. urbanensis, the testes are marked by definite cell masses, while in $\underline{C}$. konadensis the testicular masses are much more inaefinite. They are small in each case and lie ventral to the vitelline organs. The course of the vasa efferentia is clearly outlined. 

On the basis of the structure of the viteliaria the species In the cercaria stase can be aifferentiated. In $\underline{\mathrm{C}}$. cellucida tne Slands are actually spiculate in outline, flattened dorsoventrally. The viteline material is finely granular and clusely nassed. In

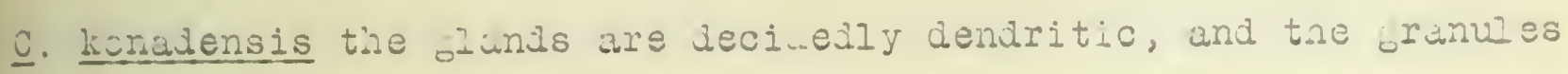
are diffuse. In $\underline{C}$. urbanensis the glands are lobate ard the fine Eranules are included within a dense mucoia matrix.

\section{Holostomata}

Holostomidae. The thickness of the tetracotyls larva, togetier with the cyst, in which the mejority of these inaividuals have been found, has prevented a study of the genitalia from stained toto mounts. However, the genital organs come out clearly in frontal sections of $M$ tinickness (Fig. 39). Whe ovary is situated just caudal to the posteriormost ruscular lapret in cercaria flabelifformis. A short ovidect proceeus dorsad, and after junction with tia viteline aucts at the ootyoe, the energing luct, the utaxus, proceeds posteriad to empty into the genital pouch (Genitalkegel). The viteline glands are long faired chords. In $\underline{c}$. flzbelliformis they ars composed of large vesicular Elands (Fig.39); in Tetracotyle pipientis (Fig. 4p) they are loosely follioular. mhe testes are paired structures which may occupy nositions from the plane of the ovary (T.oipientis) to the plane of the genit al pouch (c. flabelliformis). The pouch is muscular and opens posteriad, ventral to the excretory pore.

Inus these genital organs are typically holostome in character, ccrresponding to the main features asscribed for the aurlts by Brandes (1891), Thoss (1897), and Johnston (1904). They are suffioiently detailed in this stage of the syecies development to be of 

diagnostic value.

Heristomidae. In this family tie genital organs are situates antirely posterior to the acetabulum. The primitive genital pore, anterior to the acetabulum, has lost its connection with tre genitalia, and with the addition of ruscular elenents has assured a suctorial function.

The species Cercaria ptycinocheilus has an ovary elongate in a transverse plane, spatulate, situated just behind the coetabul wi. It is granular, compact, and stains deeply viti haematoxylin dy s. $_{\text {. }}$ At its left it merges into the oviluct, a large coiled tubule which bends in tiself three tines fust behind the margin of the ovary, then empties into the ootype iust anterior to the bursa coculatrix. The densely masses cells of theglands in the vicinity of the potype lie just above this organ. The testes are situated at the right side just ventral to the ovary. They are small compact glands, enj have no aucts at this etage of development. lhe vitelline ducts from the aiffuse vitelline follicles met the other genital proaucts in the ootype. It is very large anj muscular, and lies just ventral to the excretory bladder. Symmetricaliy arranged glands, with glandular nuclei and hyaline oytoplasm, empty into the bursa from the postero-lateral reaches. They vary in number from seven to ten in each paired group.

With the exception of these glands emptying into the bursa, all of the genital crgans of this larva lie in the anterior patelliform region. With the exception of the later formation of a uterine duct betwesn the cotyce and the bursa, all of the organs are in the approximate location where they will be in the azult morm The massing of the organs in the artenior portion of the animal 

is undoubtedly correlated with the abbreviation cf the a. endicular portion of the specics.

In the literuture on larval hemistomes (viplostomulum) v...ordnann (1832:34-35,pl. III,fig.I) describes an egz pouch fcr D. volvens and two symmetrically arranged testes, with luots, in the region of the acetabulun. Since v. Wormann has seen the egs in the uterus there is no possibility that this organ is an oviduct, yet it seems strange that the uterus has been found and the ovary and oviduct are not yet differentiated. Løiay (1904:111) describibg D. grande (Diesing), speaks of "ovariss, dusky yellow". Since the ovary in the Holostomata is single, the organs lescrioed are cossibly testes.

the bursa is the muscilar organ par excellence in cercaria ptychocheilus. Wiusole elements crotrude into the atrium, so that a constriction exists betwen the anterior and posterior portions of the organ.

The genitalia of the holcstome and the hemistome are similar in those features in which they differ from the distomes. They have modified their primitive genital pore so that it has either become rudimentary or has assured a muscular function. The sperm wets and the uterine duct empty into the bursa at the posterior end of the animal, instead of the atrium anterior to the acetabulum. The new genital pore is posterior to the ootype, and ventral to the excretory pore. 

Distomata

Xiphidiocercariae. The group of the stylet cercariae, comprising one ornate species and five without the tail fin, are probably larval Plagiorchidae. The ornite larva is closely related to the other five, but is less akin to them than they are to each other. cort( 1915$)$ believes that the finless xiphidiocercarice probably belong to the Plagiorchilnae, fromthe knowledge of the iffe-history of Cercaria lymnaeae-ovatae (Iarvul stage of 0oisthoglyche rastellus), and the opinion of ssinitzin (1905:154) who places $\underline{\text { C. serunda }}$ among the species of Plagiorchis. A much closer index is found in the comparison of the genital systers of the larvae and the Plagiorchitinae.

The genitalia in the cercariae are readily defined with reference to the acetabulum. They are situated in the midale of the vemtral side of the larva or slightly posterior to this cosition. The ootype is posterior and dorsal to the ootype. The uterus coils around the right side of the acetabulum. It ens in a blunt or tapering cell mass. Laurer's canal is on the left of the median line, just behind the midale of the acetabuium. It is present in all of the species of stylet cercariae examined. Only in two species are tre testicular cell rasses outlined. In $\underline{c}$. crenata (Fig. 5s) these glands consist of two large ovate messes. In O. denaritica ( $1 \mathrm{~g}$. 88) the testes are small, situated closely behind the ootype. In no case is the ovary clearly differentiatei fromthe region of the cotyre.

The vitellaria are definitely outlined. These glands in $\underline{\text {. }}$

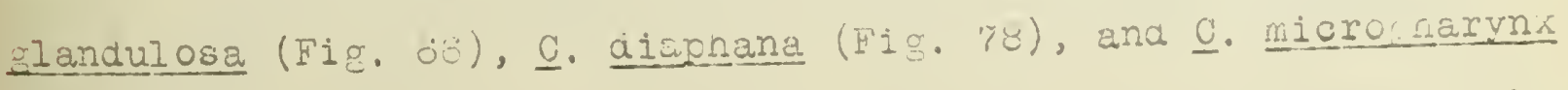
(Fig. 93) are much more slike than those in the remainjer of the

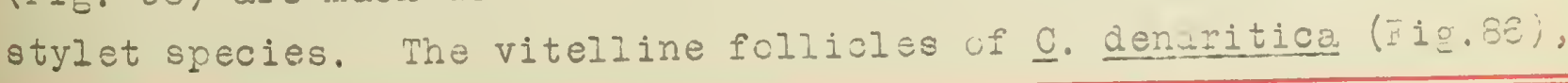



ana $\underline{\text {. crenata }}$ ( $\Gamma i \tau .55$ ) inave, on the one hand, a syotem extenling the entire lengtr cf the boxy, and, on the otier lian, a system confines to the in wejiate vicinity of thc ootyne.

The cenitalia and ducts of $\underline{\mathrm{C}}$. racemosa, the later I fil ty, e, (Fiv. 104), bear some resenblance to trose of C. denuritica (Fié. 80 ). However, Laurer's canal is very prominent in this fintail species, situated to the extreme left of tine ootype, some distance outside of the acetabulum. Instead of coiling around the risht sise of the acetabulum, the uterus in this larva makes four double oblique coils dorsal to the acetabulum. The ovarian cell mass is dorsal to the ootype and conneats with that organ thru a short zuct. The testes masses have not been observed.

Echinostomidae. The two species of this grcuc wich have veen studied, $\underline{C}$. trisolenata and $\underline{\underline{C}}$. biflexa, vary in the structure of thier ganital organs most markedly. In view of this diversity it does not seem acvisable to take them up in detail.

Furcocorcariae. The material of Cercaria gracillima was stuuleu with especial reference to the genital cell masses, both in the tota and the section mounts. The female syster consists of the ovary-uterus mass on the right and the cirrus mass on the left, both in the vicinity of the acetabulum. The vitellaria are lateral and empty into the ootyle thru transverse ducts (Fie. 14S). The testicular follicles are numerous. They are proliferatea from a posterior germ mass, which is ventral to the bladder. This larva is thot by the writer to be a schistosome, in view of its several closely related structures in the nervous, genital alimentary and excretory systems. 



\section{The Digestive System.}

The most uniform system in the Digenea is the digestive tract. rith the exception of the sub-crier Gasterostomata and the superfamily Prostomata, the enteric canal is triclad in character. The main features of difference in the various families of the group is the modification of the esophagus region of the gut. In most forms there is a pharynx sphincter just within the oral cocket. In other species the pharynx is small and inconspicuous. In still others there is no bulbus around the esochagus, but in its stead a group of gland cells.

The digestive syst $m$ in the cercaria is not a larval syster but a fully matured system. In some cases it is not functional, as in the Nononstomata, where the paired ceca are still filled with a jell (Fig. 13); in other cases, the ceca are extended in length wuring later life, as in the Schistosomidae. While the larval digestive glands of the cercaria may not be retained in the mature worm, nevertheless they represent a mature functional process.

l'he forking of the ceca is not constsnt, varying in difierent species. Even the relative length of the parts of th tract varies greatly in tne same indiviaual at aifferent times, due to the extreme limits of contraction and expansion of the larva, so that this relation of parts can not be entirely depended on for a basis of diagnosis. As a whole the direstive tract is remarkably uniform and simple, as might be expectea in a larva in which the food supply is so accessible.

The sporocyst has no digestive tract, but taks its nourishnent airectly thru the bouy wall. In consequence the cells of the epidermis are thin and at times apparently glandular, as in the 

stylet cercarias.

The reala has a gut-pouch for a dicestive system, with a gharynx sphincter around the anterior end. Hence the epiuermis is not used in the capacity of food trunsference, and is heavily lined beneati with an integumentary secretion. For securing fool the redia of Cercaria Eellucidais providea with an oral pisrcing organ. The redia of $\underline{\mathrm{C}}$. flabelliformis is equipped with pairec muci-salivary slanis. 



\section{The Nervous System}

Une of the earlier and better krow systems of the adult trematole was the nervous system. Leuckart (1833:132) states that Bojanus and Mehlis were familiar with the gross anatomy uf the nervous system of the larger flukes, and that von Laurer, Diesing and Siebold as well as the elder van Beneden were acquainted with the systems of both the large and the small worms. Leuckart jescribed the system for Fasciola hecatica anj F. lanceolata. He states that there are two or three stems and proceeds te describe the anterior dorsalis and anterior lateralis and the thick costerior ventralis. Somewhat later we have the stuiy of the same worm by Lang (1880:46-50), who substantiates the work of Leuckart, and in adition describes the aorsal posterior and acetabular innervation. Wore recently Gaffron (1884) and Louss (1892,1894, 1895) have placed the nerve anatcmy of the adult trematode on a firm foundation.

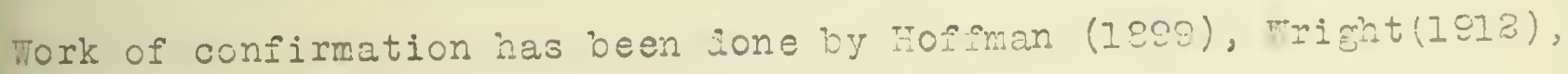
and konticelli (1914). Nor has the finer work of the nerve entings and the ganglion cells been overlooked. fany of the earlier writers have made out the ganglion cells of the pharynx region and have scorded their observations of the nuclei. Bettendorf(1897), working on Fasciola sepatioavith intra vitam methylene blua and Colgi methois, has brought out clearly anj convincingly the nervous system of this worn. This stujy has been augmentei by the work of Zailer (I9I4).

In view of the extensive study of the nervis systen of the adult trematode, it is a matter of no little surfrise that so little has besn done on the nervous structure of the cercaria and the parthenita. Looss(I394: 245$)$ has confessed the aifficulty in 

making such a stulyand has observed thut"e1n, wie es sche1nt, niaht unbeträchtlicher cheil derselban fällt in aie zeit der Cercarıbontwicklune, unj weiterhin, ist auch zer eanue hp arat wïrerid sin or Ausiliungzeit, dass es mitunter recht schwer ist, zu entschaiden was zu 1 hm unj was zu jem umgebenden farsnchye cun̈rt." me wonders why Looss ïia not usea rreserved faterial for his stuly cf the nervous system in thelarva or avail nirself of intra vitars rethylene blue technic. By the use of an eosin counterstain wainst a hasmatoxylin background the writer has been able to oecure rexarkably clear sections showing with extraoruinsry delicacy tue nerve branches as well as the certral nervous system. It is the purcose of this section of treratcae murholoyy to rresent lata and observations on the devalupment and structure or the nervous system in partrenita and cercsinia.

the central nervous system of the adult trematode corsists of tmo central ganglion masses, situated dorsal and luteral to the fharynx and yckea tozetiner by a transverse commissure passinz worsal to the pharynx. The apcearance of this structure nas been aptly describej by Lang $(1880: 46)$ as a suldie between oral sucker ans pharynx. In cross section it is lunar. Here are centered the rost of the ganglion cells, altho they are frecuently found

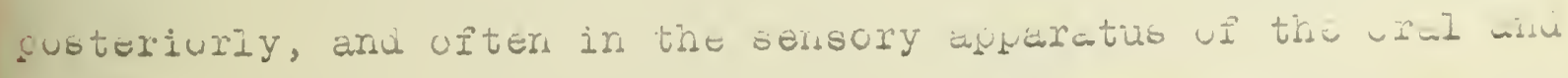
ventral suckers. Ihe system alsc has a subssophacjal comissure Which liffers in size and shape in different species of fikez. Exterisig forward into the region of the oral sucker are tires Fairs of nerve trunks, the dorsalis, literelis und ventrilis. Jf trese tiree the latter is the must fully arveluzed. It has $a$ ranus muscularis which is botr motor ani sensory (zailer), and 

an extensive cunrection with the ordi nerve rirg. The urtericr laterglis is also a strongly a-veloret trunk, with a renus unscularis and a ramis ralralis, and trarsverse ccmissures to the unterior torealis and costerior lateralis. The untaiur ivisalis io a weakly developed nerve which innervates the as icul usrsory fiel.. $\Lambda$ transverse comissure connects the two dorsiles uncve the heas muscle shesth. In auition to these three crimary trunks, the ralatirus, a weak notor nerve, Iies internil to the anjericr ventralis. Postericr to the centrel nervus system are the three lustarivi truiks, the vorsais, Luterails ariu vertralis. The vertrai trunk is by far the mest strongly developed. In addition to these is the small but consoicuous internal branch of the ventrelis knom as the pharyngealis. It occuries a costerior position, corresponifig to the pelatinus arterior to the central rervous system.

braun(1893:685) consiliss the ventralis, dcrsalis ari pharyngcelis to be the trree pairs of posterior nerves. Herever, tie corsistent course of the lateralis tc the posterion extrenity of the body, its carly appearance in the enbryology of the worm, and its conmissural connections with anterior lateralis and postericr dorsalis surely oroove its right to a clace in the rank of the primary posterior nerve trurks.

the nervous syster of the morostomes has oesn worked out oy Jägerskic̈ld (1891), for Omogaster kicatus(Cres.), and by "Nonticelli ans Locss for Catatropis verrucosa(Frol.). Locss (IEso:I49) consilers the systsm similar to the Aistome tyre. "Je n'hésíte pas à attribuer au systéme nerveux de notre ver une construction aralogue à osile cue rous avors désáa sienal'é chez 



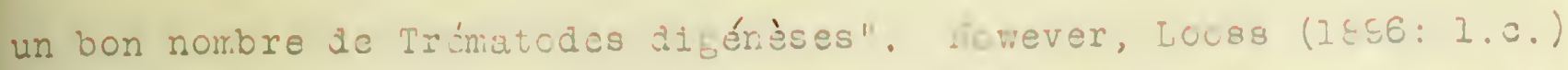
wes rot dble to meke cut clearly tile antericr trumke. Jagerskicld (1501:14-16) descrikes accurately and in detuil the cerebral ganElion masses with the trinsverse comrissure, the zost rior ventralis, dorsalis and lateralis, and tre three anterior trunks, short and thorn-like, the homologs of the dorsalis, lateralis and ventrais. $\Lambda$ sten, designated as the "fourth", arisine from ths anterior reaches of the cerebral masses, passes ventrad to the region below the oral sucker; this is rossicly the genitul nerve, but seems more probable that it is the palatinus. Ire only real nirification from the aistome type is the absence of the acetabvilar innervation, due to the loss of this organ.

ihe Schistosomias, altho distomes, weviate in certain respects from the tyrical aistome in their nerve anatomy. The systen has been worked out by Looss (1895:30-63) for Schistosona haematoilum. Antericrly all of the nerves are found excent the nalatinus. In the region posterior to the contral nervous system, however, there is a markez change, aue to the complete absence of the lateralis, and the fusion of the aorsalis with the vertralis in the region of the acetabulum.

In the Amphistomata zults among the earlier writers Lejtenyi (1881:142-144), working on Gastrosiscus polynastos Leuck., describai two ganglion centra with the dorsal comrissural briage, but with only one anterior and one posterior pair of trunks. In contrast to this simple descriction is that describey by Losss (1896:21, 2z) for Gastroaiscus aegyrtiacus (Cobb.), where the verual distcme nerve trunks were found, and in addition a median anterior and a median posterior nerve. Lcoss has also worked out the nerve 

anwtomy for An.ristonum subclavatum hud. in evon graater letall

(1852: 151; Taf.15, figs. 1, , ), and finds that they corres, cnd

to the distore type, except for the inrervation of the pusterior sucker.

The one group of the Digenea where the nervus system had been almost entirely neglected is the Holostcrata. Hrandes(II9I) states that none of the workers of the nervous system up to his day have worked on the holostomids. He has observed only the central nerve center lying above the posterior portion of the pharynx, an anterior and a posterior pair of nerve trurks, the tracings of which he has found in sections. Ihoss(1897), working on Holostomum cuculius, finds the main nerve center lying dorsal to the origir of the esophagus, with two pairs of anterior and one pair of posterior nerve trunks.

The observations made by the writer are based on frontal sections of the larvae of the various groups of cercariae. For the study of the echinostome cercariae and parthenitae wax models were constructed from sections and sketches made from the drawings (Fig.s. 121-1z5). In aciition to these, detailed camera sketches have been made of monostome, holostome, schistcsome, and xirnidiverCariâ groups.

The central nervous system of Cercuria trisolenata, the echincstome, consists of two masses of ganglion cells and the dorsal comissure lying concavely on the dorsal side of the laree muscular pharynx. The commissure is broad ani flat. The dorsal surface of the ganglion masses and the commissure present a smocthIy curved surface, but on the ventral side the ganglia bulge out against the pharynx. The antericr trunks consist of the dorsalis, 

lateralis, ventralis and the palatinus. The falred iursales arloe together with the laterales and croceci forward with them for some distance. After separation, the dorsalis runs more wedir, then flexes outwari und dorsalward over the oral hood, foceenirg toward the apical senscry center. The lateralis at the foint where it leaves the dorsalis procesds outward and forward, so that it reaches a level slifhtly belov the plane of the central nervous system. Slightly after aiverging from the dorsalis the lateralis

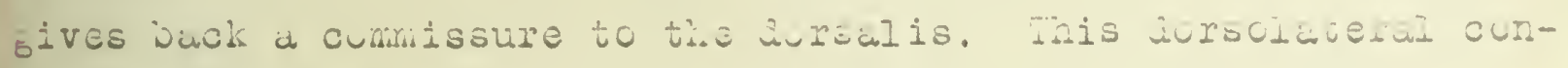
nective Iuses with the dcrsalis just behind tie costericmost branching of this trunk. Arising from the most ventral reaches of the ganglion center is the ventralis, a broad flat trunk, which courses outward and downward to the oral lip of the oral sucker. Interally it gives off the palatine, which lies just lateral to the pharynx.

Caudal to the central nervous system arise the four cairs of posterior trunks, the dorsales, the laterales, the ventrales and the pharyngealss. The dorsalis arises dorsal and slightly lateral to the iunction of the ganglion and the comissure. It runs straight backward,slightly dorsal to the plane of the central nervous system. The lateralis arises slightly lateral to the acrsalis; its cath lies outwars and backward. The ventralis arises from the very heart of the ganglion mass. It spreads outward and then runs backiard parallel to its wate. Just rexian to the origin cf the posterior ventralis arises the pontral commissure, flexing below the precharyngeal ocening. It is stout and bowed considerably downward. Eetween the conissure and the ventralis arises the pharyngealis. 

In a eerm ball of Cercaria trisolenata some $5 \mu$ ty $6 r \mu$ in size, the central nervous system is well developed. Tnis may be called the "butterfly stage" (Fig. IDI), from the aneral rasemblance of the central nervous system and main trumks to a butterfly. At this feriod there are two fairs of main trunks antarior and fur fairs posterior to the central ganglion mass. 1.te anterior trunks are the ventrales and the laterales. Dy reference to the next stage in the develooment (Fig. İE), we note that the dorsales arise from the sinus between the laterales buds of fizure lil. hey arise at first as a sinle bud, anj bifurcate later. Cauialiy the most consficlious trunks are the lorsales, which arise ir a nezian Fians and consnicucusl* donsal to the other nosterior trunks. Ine donsil comissure at this period is practically regigible. The outemost ventral trunk-buas are the laterales, short and stubby at this feriod of growth. Ine ventral trunks arise from the ventral cortion of the cerebral masses. Detween them and the laterales arise trunks which are present in the embryonic stage only. Thej will be designated as the posterior intermedius. In stage II (Fig. IzZ) a very decided change has occurred in the outline of the central nervous system, altho the funiaments of the first stage described are present. Anteriorly the intermediate space between the laterales has disappeared and from that region has arisen a wedge which is the funlament of the paired Lorsales. The ventral trunks have beenset off to themselves by a lateral growth and elongation of the interrediate fibers. On the caudal side of the ganglion the posterior dorsalis has been separated from its mate by the growth of the dorsal saldie commiosure. Most noticeable, however, is the change that has taken place 

in the ventral fortion of the syotom. Here the space between the ventrales has become exceptionally wide ani a yroninent commissure has grom out from the trunks, comnonly knom as the subesophageal comissure. It is the homolog of the transverse commissure occurring along the entire ventral sizo. The intermelius trunk has become fused with the posterior lateralis, in part, and then crosses over to the ventralis. This is the connection know in aiult nerve anatomy as the ventrolateral commissure, a strung and im ortant intercomunicating trumk (Fig. I23). In the developmental stages no trace of falatinus or pharyngealis has been found.

Cercaria glandulosa is favorable material for the stuiy cf the minute structure of the nerve fivers and ebrings. In the anterior end of this larva there occur in five frontal sections of 8u thickness all of the fundamental nerve endings of this region. In section 1 of the worn the most dorsai section, there are no nerve structures save a fer sensillae to the dorsal 1 ip of the oral sucker. They receive innervation from the anterior dorsalis, and Aerive thut innervition from the anterionncst fioers cut off in an oblique plane beneatin in section $z$, just in front of the musculus preoralis. Saction $2,($ Fig.68), shoms the trunk of the dorsalis descending into the oral musculature. It has thrae main brainches, one coursing to the preoral region to supoly the conductive strinds for the preoral sensory endings, one becoming the short supericialis, and a longer one, the profundus, passing under the endings of the superficialis. In the region of the musculus preoralis, the apical sensory field is continuous across the sucker from right to left. Passing to section 3, (Fic. 69 ), we find the main outlines of the central nervous system, together with the anterior 

trunks. Here is the loisal fortion of the fanglion colla. Arterior and acrsal is the dorsal cormissure and ventrul is the suveophajes commissure. The forward traves are the trunks of the lateralis with the outermost sucerficial ramus palpalis and the more locely situated ramus muscularis. The latter branch innervates the muscuivs preoralis and the anterior lif of the orde sucker. On the loft is the trink of the anterior ventralis, arising frou below the mass of the ganglion cells. At the anterior extremity is the yrical sensory field. The dorsolateral comissure is very clearly shoon in this section. Section 4, (Fig. 70), shows the remainuer of the central gangia with the left anterior ventralis passing forward. This is a large trunk, with an especially important ramus palpalis leading to the aplcal sensory field, and a small oral nervus communicans supplying the oral nerve ring. This rirg completely encircles the superficial regicn of the oil sucker and connects with the surerficial branch of the dorsalis. The ramus muscularis of the ventralis and the palatine branch of the ventralis are found in section 5 (not figured).

Passing caudad all the posterior roots are well defined. Four posterior roots are visible in section 3, (Fig.39). These include the posterior dorsales, laterales, ventrales, and pharyngeales. In a fortunately cut section of the same species the innervation of the acetabulum is beautifully demonstrated (Fig. MI). The tho ruin longituinal trunis, the ventrales ani the laterales, are connected by comissures. Those around the acetabulum are of especial importance. The preacetabuiar coumissure arises from the alteral trunk and proceeds in a posterior oblique ciurse, then around the anterior reach of the acetabulum to meet the oranch 

frum the uther siae. Tho postacetabular branch arieca frim the lateralis also, but continues caudad along the cuurse of the ventralis. Behind the acetabulum it meets the branch from the copooite side to form the span. From these trunks circumscribing tine acetabulum two ring commissures arise, a superíicialis and a profundus, of which the latter with the nerve endings is found in the section (Fig. 7I).

the nervous system of the monostome, as worked out by Järerskiöld (1891: Taf. I) for Omogaster clicatus (Crejl.), has been substantiated for the most part in the study of cercaria pellucia. (See figure 23). The three paired posterior trunks are evident. The posterior ventralis is the most important of these and can be tracea to the caudal extremity of the animal in all cercariae

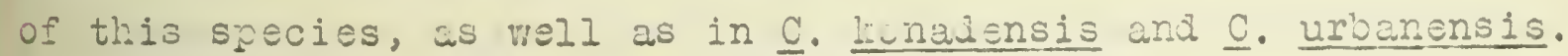
The dorsalis is less conspicuous, Jet it is usualyy traceable far caudad. The posterior lateralis is delicate. It arises near the origin of the ventralis $2 n$ swings out laterad in a great bow. It, too, can usually be traced to the posterior extremity of the bosy.

The anterior trunks can also be definitely traced. The ventralis arises from the extreme lateral horn of the ganglion center in conjunction with the posterior ventralis. More median, the anterior lateralis is found. The two anterior dorsales arise as a single structure along the median line. Their primary function in the cercaria is the innervation of the median pigment eye, altho branches may be trasej farther anteriad. Iikewise, an important brench of each posterior dorsalis foris the nerve tract to the laterul eye. 

the gunglion eells in thercnostcres are superficial to the nerve strands. A cons1derable number of them are not even in intimate contact with the fioers, but have fibriliar communicaticns with them. The ganglion masses frm which the nerves arise are Aistinctly cornuate, with a vide dorsal coririssure.

Pigmentation and eye-spots in the monostorss. The monostore sercarlae that have come under the direct observation of the writer, together with those described in the literature, uay be Flaced in two groups according to their eye-spots, namely, those with a single fair of eye-spots, aisposed laterally to the brain center, and those with an alditional melian eye, anterior to the central nervous system. The amount of pigmentation is considerably larger in the trioculate species than in the bioculate type. Figures 1 to 3 show in dorsal view a series of stages in the pigmentation of cercaria pelluciaa. The cigment originates anteriorly over the brain center and proceeds caubad along six lines of gronth. A very careful study of ths pigmentation in these species indicates that a very simnle but reasonable relation exists betrein the pigen ation chi th unjeriying nervous system. The pirmentation is found to be a delicate index superficially of the vnderlying nerve fibers. This pigmentation is present in the suiointezumentary areas and follows with precision the racenations ani. dentritions of the nerve enuings. Figure 37 shows the nerve endings in the anterolateral reaches of Cercaria pelluciaa. The animal is probably sensitive to light or heat impressions thru this medium.

In the caired eye-spot a definite subspierical "lens" is fourd in the region of the concentration of the pignent. In the meilan 

eye of the trioculate type a melian eye "lens is sometlacs greser. The origin of the eye is simple. At an early stige in the eedm ball ( $60 \mu$ to $80 \mu$ ), when the cell masses of the nerve trunks are definitely outlinei as they energe fron the gunglion center (Tig. 33 ) a branch of the posterior dorsalis. larjer than ary cther ne+ve, Frishes out obliquely. It meets an invigination $f$ the ectodemal layer, which may be considered an "ortic cup". There soon fomis in the hollow of the cup a quantity of dark brow refractcry granules, which entirely line the optic cup several layers desp and leave but a small cavity within. The optic branch of the jorsalis benjs back into the cavity at tine place where it first cones in contact with the cup and hers ends in a ryriform enlargenent, the nerve cell. The structure of this end organ is such that it might be interpretes as a "Iens", if the ccnnection with the nerve is not made out. Cort (IS15:15) has placed that sort of an intercretation on the eye structure of $\underline{c}$. ureanensis and $\underline{c}$. inhabilis. For the former he states that "each true eve is fumed by a mass of piment in the form of a cup, the bottom of which is thicker tran the sides. A lens fits into the opering of the cup, leaving a space between its lower surface and the bottom of the cup". Ama again, for $\mathrm{C}$. inpabilis, "the large eyespots.....are cumosed cf the lens and the cone of pigment like those wreuiy wescribej for the monostome, Cercarie urteanensis". ihe writer has stuäied some of Cont's material and has found secticns wiere such an internretation might be made from a single section. Lit in the creceding on following section the connection cf this "Iens" with the oftic rerre is clainly sean.

Ine eye structure as studied in this ronostome is si. ilar to 

that found in the lonoenea, es:scially the tyre ir Trietcris toles. costericr eye (fesse, 155: 555 ; Tuf. 28 , f1s. is). The nervous systeil. of the monogenetic trematude was first stulied in jetull by Lang (18SC), who male cut the pigment cup, a refractcry coly (11chtorechenier körper), a ganglion cell, the retina, whi cye ruscles (I.0.41; Taf.I, Iig. a, Tuf. II, fig. j). "cst later investigators ention only the rerceptory boly and the accesscry wiraratus, atho Aniré (1910: 17 ) has idertified the miscle fibers of Ling. The general concensus of opinion is held by the writer, that the movement of the eyes depend lareely on the general bodily rovement. In the adult Wonorenea stried the zigment clif is fiund to lie between the refractory oult of the eye and the possiole scurce of light (Goto, 1684:81). In the moncstomes, as in Deniruooeliugh lacteum (Fesse, I3อ7: Taf...7,fig.10). the hollow of the cup is directei outwara, so that light fallirg on the eye must pass thru the end organ oefore reaching the inner portion of the pi ment comiclex.

The rigment of the orgunism is probabiy the waste prosuct in the metabolic econony if the worm. Its close association with the nerve endings in the monostone cercariae seerns to indicate that it is the melanoizin fraction of the oxidetive processes in the nervous system. The possibility utility as a recector of light or haat is a sccondary itern and must not be confused with the crimary mearing of the pignentation.

In the free-living Platyhelninthes we have the fuliy developed eye in the meture inivivual. In the cotoparasitic treratcies the eye-spot is well developed in the young animal (hesse, Ic37: 560,561), but de,ensration takes place as the arifal matures. 



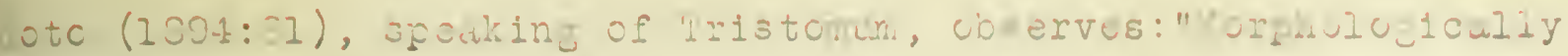
speakingthey are certainly degererutz eyes; and have grbeñy jesn Srivod from such eyes as aro fun. is Tuaceliur1a; but I io sot thinh they are furctional. In the first gloce the wi rat gr... liles are situated on the lorsil side wni thus frevert the Iifft from reachin, the lens, sirce the dorsal side is the vily airecticn from which light can conc. In the second slace thane is rot wlways w aistinct retina. If these 'eyes' are really still useful to the arinial, they may possibly be a temperature sense orgun; und for tiat purpose their structure seers t o answer well." Goto zoes on to show that the more legenerat- acruition of the eyss in Iristomun cvale is due to the greater degree of internul purasitism of this syecies than that of Tristcrum molae. In the wonostone, the eyes are WeIl develoged in the cercaria but become fully legenerate, with a loss of all the rigment, in the adult. so that the adult of one soecies has been described loy Craplin as "albiłus" (Jägerskï̈ld, 1891:1). A still further stage uf degeneracy is found in Cercaria racemosa (Fig. 100) and $\underline{0}$. grecillima (Fig. 14!), where the cptic nerve is still present but the cigmentation is aosent.

In Cercarie sarillina, the representative of the furcocercarise, the nervurs system is narrow, in corresconjence with tine attenuate conition of the animal. The rosterior laterales are not found in the maturs cercariae, al tho the bud is present in the germ bali (Fig. 151). One is struck by the siorificant resemblance of the main nerve complex of this osrcaria anu that of Schistosoma naematobium, described in detail by Locss (1855). Ths three pairs of anterior trunks are readily found, altho, in aditicn, 

a prominent dorsolateralis is found(F1g. 150). The gesterior lorsalis arises from the dorsal side of the ganglicn cell mass and procests caudad to the region of the acetcitulum, whore it fuses with treventral trunk. A prominent subesophaceal conis isure and a snall pharyngealis are cresent. The funanental resemblarce between the system describea for this cercaria and that for the schistosome adult secms to the writer to be the most exact morchclogical eviaence possibls for the correlation cf these artaryngal furcocercariae with the species of the schistosomilae.

A stualy of the nervous system of the Holostomata has been made on Cercaria otychocheilus, based on both toto mounts and sections (Fig. 53). No adequate idea of the nervous system of tis group can be secured from the meazer abta of Brandes (1891) and Thoss (1597). The dorsal conmissure is indistinct and thoroly fused with the ganglion masses. The latter are wide, with a ccnstriction in each in the region of the origin of the lateral trunks. The trunks figured by Thoss are probably the ventrales, since they supply the main innervation of the animal. The anterior rentralis arises along with the posterior ventralis just anterior to the latter. The anterior trunk soon divides. The major cortion runs around the oral sucker, while the external branch is traceable anterolaterad. The anterior lateralis is represented by a blunt stock just outside the pharynx. It rins cephalad but soon ends in two delicate branches. There is no posterion dorsal or posterior lateral. The posterior ventral is stcut and thick. It givss off one prominent branch extemally soon after it reaches its most external position. At regular intervals it cives off branches internally which have the inlication of rudiments of comissures. 

These trunsverse trunks just anterior and costerior to the scetabuium are st1]l well. developed; they are sinilar to those lescribed for the distome.

Contrary to the opinion of Looss (1894:245,246), the writer has found without exception that the general trematcie nerve anatcmy can be traced in the early germ balls, and that the cercaria shows not only the potentialities of the adult system, but actually all the details of this system. Moreovei, the study of various groups of cercariae has demonstrated, that the fundamental deviations and nodifications frcm type are recognizable in the mature cercaria. This study has shown, norecver, that the nervous systom of the cercaria is constant for the group to which it belongs, and is a definite basis for the natural classification of the groups. In contrast to the highly developed nervous system found in the cercaria is that of the parthenita. In the sporocyst no definite nerve complex is fcund, altho Looss(1892) has observed nerve elsments in miracidia of Amristomum subclavatum. In the redia, however, with the continued functioning of the highly muscular pharynx, there is a nerve complexpractically emoracing the entire anterior cortion of the gut (Fig. 125). Viewea from the dorsal, ventral or lsteral aspect, the system presents an $H$ in surface view. It is resolvable into four anterior trunks, four posterior trunks, and a ring comissure. On the dorsal side are two swellings, the rudiments of the cerebralganglion masses of the cercaria. The nerve cells of the system are very prominent. They are usually bipolar or multi olar (Fig. 1z6), but, as might be excected, the more superficial ones are more often the mutipolar. 

This redia-nervcus system constitutcs a very frimitive type, in which the nerve cells wre much more freyuertly diffuse ana nore discrete than in the systems in tho cercariae. It is ercbable that the charynx is responsible for keeping the systen from tctal degeneration.

The size, number and location of the ganglion cells vary according ti individual species of cercariae. They may be situated within the ganglion centers, as in Cercoria microrharynx (Fig.97) and C. glanduIcsa (flgs. 69,70); they may be scattered arcund the ganglia altho not imbedued in the fibers. In the redia of

C.trisolenata the fibers are less conspicuous than the ganglion cells. Species closely related may have cells of different numbers and different sizes. In $\underline{\mathrm{C}}$. microoharynx there are always iust two ganglion cells, imbedded in the fibers, just abcve the esophagus. Their nuclei are large, pyriform, and usuelly containing conspicucus refractcry nucleoli. They measure $5.5 \%$ to 6 ir in short diameter by $8.5 \mu$ to gu in long aimeter. Whe nucleoli are about $2 u$ in diameter. Cercaria ganulisa cresents a case where there is a definite number of mirute ganglion cells within the ganglion masses. There are fifteen cells in esch of the tro masses. The cell walls are not well defined, but the nuclei are readily distinguished. They measure $3 \mu$ to $1.5 \mu$ in short aiameter by $1.5 \mu$ to $2 \mu$ in long diameter. The ganglion cells of $\underline{\text {. }}$ pelIucida are numerous; it has not been ascertain whether thay are constant in number. They are subscherical at times, but are usually multirolar. They average $3.3 \mu$ by $6 \mu$ for the entire cell, while the nuclei measure $1 \mu$ to 1.6m. The cells of the redia of . trisolenata are usually multipolar in the region of the 

epidermis. They renge from $6 \mu$ to $22 \mu$ in diumeter. The nucle1 are inconstant in size, varying from w to $6 \mu$ in alameter. The nucle1 of the ganglion cells o: C. griclilima are so minute in the nerve complex ir the germ balls (Fig. 15I) that they ire barely visible under 1000 magnification. Yet these buclei are definitely set off from the surrounding matrix. They measure about 0.4u in diameter.

In cell-studies of adult trematcdes the nerve cells have been measured in many cases. The measurements range from $80 \mu$ in Gastroaiscus polymastos (Lejtenyi, 1881:4I) to 6ii in 0pistlotrema cocleare (Fischer, 1os4:17). The nuclei ranefe from leu ir Femiurus oxcisus (Jual, 1889:41) tc 1. Eji in Coistbotrema cocleare (Fisher, 1.c.). A comparison of these measurements in aiult trematodes with those for the cercariae, shows that the nuclel of the aduIt cercariae are on the whole as large as those of the adult tremetoke It is evident, however, that the cells as a whole are much snicillet. in the cercariae. Ageing for these cells consists, then, in the growth of the cytoplasm rather than an increase in size of the nucleus. 



\section{Descrittion of the Aganic Trematcles}

of the Bitter foot Valley

\section{Mor tana}

On account of its geoligical and biological isolation it is little wonder that the Bitter Root Valley contributes new species of trematodes. The fourteen scecies of agamic trematcdes fcund in the Valley are not thot to comprise the entire trematole fauna of the the region, but are the representative species for tire year and season when the study was made. Of the fcurteen species found in the Bitter Root River, two are larval Lonostorata, tivo are Holostomata, and the remainingten are Distomata. In ajiltion to these, an agamic Holostorata, Ietracotyle picientis nov.spec., from the vicinity of Chicago Ilinois, is includej in the study for the sake of comparison.

There have been describej previously from Ncrth Ainerica the following aramic trenatodes:

\section{Munostcmata}

Cercaria hyalocauia Halsenann 1842

Glenocercaria lucania Leidy $187 y$

Cercaria urbanensis Cort 2914

Amphistomata

Cercaria inhabilis Cort 1914

Cercaria diastrooha Cort 1914

Cercaria goronocephala "ard 1913

Distomata

Cercaria aoilis Leidy 1058

Phc elocerca tardigrada Leidy 1858

Gymoceohala asciodea Leidy lomp 

Cercaria Rlatyure Le1uy luco

Cercaria reriexae cort lclt

Cercar1a meealura Cort 1914

Cercarta lertacantha cout 1014

Cercaria caryi Cort 1914

Cercaria isocotrlea Cort 1914

Cercaria brevicaeca Cort 1914

Cercaria polyalena cort 1914

Cercaria hemilophura Cort 1914

Cercaria trigonura Cort 1914

Cercaria trivolvis Cort 1914

Cercaria ruora Cort 1914

Cercaria douthitti Cort 1914

Cercaria wrightii Ward 1916

Cercaria anchoroides ward 1916

Cercaria marciande (Distomiun) La Rue 1917

Cercaria vergrandis (Distomulum) La Rue 1917

Holostomata

Diplostorulun outicula (v̈. iTordmann i832)

Diplostomulur grande (Diesing 1850)

Diplostomirun volvens (v. Murdmannlez2)

Tetracotyle tycica (Diesing 1858 )

Diplostomium parvuium (Stafford 1904)

Cercariasum

Cercariaeum helicis (Leidy la47) Also recordal by Leidy as $\underline{\text { C. }}$ vagang $(1850)$

In adition, there is the doubtful form, Cercaria bilineata Hal amann 1840 

Mccording to Stlles and Hassall. (1908:15\%) Le1dy 1s credited with the recorü of a specics, Diplostomulun rhichiacun. (Henle). Investi ation of the literature shows this to be an error, owing to the confusion of the names leily and Leydig. Fr. Leywig described the species D. rhachlaeum for Europe in 1853 (Leyi12,1853: 383).

Of the thirty-two forms listea, it is doubtful if any except those describe: by Cort(1914), Nard (1916) and Lapue (1917) could be recognized by their descriptions, since in the majority of cases the aata are so Eeneralized or so indefinite as to leave the systematist a wile range of choice in determining the species. An excellent examele of this valueless type of description is afforded in the form Diplostomulum cuticula (v. Normann 1832), reported by four American investigators from various localities east of the Rocky Hountains. The descriptions include larvae encysted with pigment and without it, some specimens fcund subdermaly, others taken from the peritoneun of the boay cavity, secured from a great variety of teleost fishes. In none of the descriptions is there mention of the course of the excretory system or of the genital cell masses, both of which are essential to the exact determination of the species. It seems reasonably certain that a careful revision of these forms described as Diplostomulum cuticula(v. Wordmann) would in the discovery of several new species of Diclostomulum.

The species of cercariae and agamic trenatodes describex in tis section of the paper have been sturied with syeclal reference to the excretory, genital and nirvous systems. 



\section{Donostunata}

\section{Cercuria veliuoiad Faubt lyl?}

this species of larval trematode is a relatively muscular cercaria, characterized oy heavy anterior pigmentation on the lorsal surface, centered around three foci, the paired lateral eyespots and the median eye. This frorm is, then, a member of the trioculate group of the Lonostonata. The riomentation tends to spread caudad from the pigment center alcng six lines of growth, two dorsal, two lateral and two ventral. These lires of firisent have been show (c.) to be the sunerficial index of the linderiying nerve trunks. At a glance the ciserver notes I) the geliucid appearance of the body, z) the circuit of refractory granules that mark the excretory system, 3) the small oral sucker, and 4) the large longitudinal musole bundes of the tail. Cercaria cellucida was cbtained from ivmnasa ercxima lea in the Bitter Root River in the vicirity of Corvallis, Hontana, and from Physa gyrina Say near the Buckiouse Bridge. The snails were exarined in cotober IOIb. Inmaea croxima containsa a heavy infection with this scecies, along with a Iesser infection with the monostome cercaria, ‥ konadensis, and a distore Iarva, ․ diachana. The Physa was heavily infected with an echinostome, $\underline{C}$. trisolenata, and contained only a light infection with the monostome. In all cases the infected organs were the Iiver ceca.

The cercaria when mature has an average measurement of $0.4 \mathrm{~mm}$. to $6.7 \mathrm{~mm}$. in lengtr and $0.18 \mathrm{~mm}$. to .2 $\mathrm{mm}$. in viuth. The tail is abcut $0.5 \mathrm{~mm}$. Iong and has a diameter of $0.07 \mathrm{~mm}$. at the base. lost usually the animal assumes an elliptical constricted cutline, such as is show in figure 4, but when relaxed it becomes elongate 

ovold or spatulate condition, shown in figures 1 to 3.

The parthenita is a Iarge conspicucus ruia, measuring $2.2 \mathrm{~m}$. by $0.5 \mathrm{~mm}$. (Fig. 6). Within the redia is a large rhabaocoel gut extenling almost the entire length of the animal and msasuring $0.3 \mathrm{~mm}$. in cross section. The gut emcties anteriai tiru a muoular bulbus $15 \mu$ in 1 ength and $12 \lambda$ in cross section. It is spinose internally (Fig. wo). In the prepharynz ragion is a unique niercing organ (Fig. 17). This organ is grobably of ectodemal oricir, as jeterminej by its location and structure. It is four-lobed und is covered with snines. A rythnic eversion of the organ against the host tissue and rearawal within the pharynx region of the parthenita is the most characteristic movement of the reaia. Around the muscular pharynx is a ganglicn mass consisting of a fibrous matrix and a network of ganglion cells. Bering the heat ragion is a neck-like constriction, and behind the neck is a sacculate body. At the extreme costerior end is a large papilla. The redia is covered with a non-cellular tunica endogena, and imbedied in this superficially in the form of minute tuberosities are the remains of tise epidermal nuclei (Fig. ZZ).

The walls of the rejia are weli supplied with muscular Iayers, longitudinal and transverse, so that the panthenita is capable of extraordonary distension and contraction, altho it has no scecifio loconotor organs.

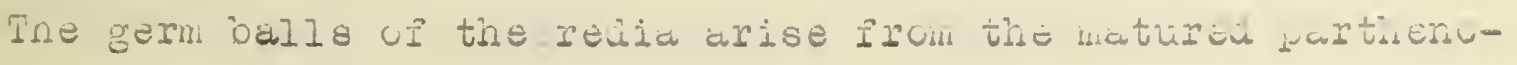
genetic ova, derivez from four cells localized at the posterior extremity of the parthenita. Altho the cells iying naxt to the wall around this quartet may pe potentially germ cells, they take no kait in tho orinary proliferation of gerw cells (Fig.ż). 



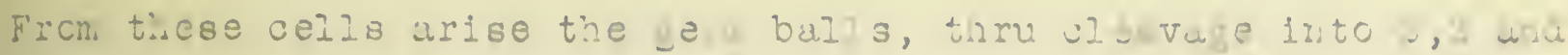
5 csils, after which asrtuin celis of the bill angear wush smalier than the others anf grow over tise lattar, eiving rise to tie gustrula by exiboly. The joung germ balls usually lie en masse behind the sut, while the ncre uiverosa asacariae aro croususa snterior. They appear strengely grotesque, with their fi wert eyes arj their snout-like boliss oscilizting buck and ferth unier tre boly wall of the parthenitu.

Aside from the larger size of tia body wha tine triocuiate anterior ena, cercaria pellucija uicht oe at firet cunfused witi cercaria urbirensis cort. Wile the size ini aye-spots sre suificient to secarete trese two spocies, a more careful exaririticn shows that there has not asen a sejaration of two s.ecies at ull, but more correctiy two grours of s?coiss. Tho smaller snecies Ercup is bicculate ard rarees arcund $0.3 \mathrm{~mm}$ to $0.40 \mathrm{~mm}$. in I engti by $0.1 \mathrm{~mm}$. tc $0.16 \mathrm{~mm}$. ir vidta, mile the lareer scecies is triocuate ans averages around $0.5 \mathrm{~mm}$. in length by $0.15 \mathrm{~m}$, tc $c .2$. m. in wath. ConsegientIy from a surerficial descricticn like ticere is no means for secorating Glonocercarie luaaria Leîy from the Bitter fott srecies Cercarie cellucia. It is such a croblem as this that 3 as caused the writar to believe that there are characters more deecly seated in the larva that will reajly set it off from others of the same group.

Sufficient care in techric makes it cossible to bring cut very clearly ant contincingly the genitalia of the Bitter Rout syecies. Fere are charecters, constant butí in the icrvu anu the aciult. These have bein described in jetail in the section ievotea to morphology (c.69) and neak only to ce sumrarized at this 

coint. The nelian vary iust in front of the axoretcry iladuer onens out thru a short luet at its left (Fig. 18), aru after receiving the common viteline iuct, opens unteriud inte tre uterus. Ih1s organ has an cutlet fust beh1nd of the meilan eye. It ends in a foorly developed vagina. No Laurer's canal has been isfinitely made out in the totos but there is evidence of such an organ in sections. From the sijes ani silghtly cavdad tc the ovary tio closely massed teates open into filifom efferentia wioh unita anterior to the ovary to form the vas deferens. This canal is Airected forward parallel to the uterus, ening in a bulbous cirrus couch ilist to the left of the vagina. The threecaired outer vitelline follicular masses ant the five peired inner masses occupy a corsal position. They are irregular in contour (Fig.4), with aciculate margins, ana are finely granular with close massing of the granuies. Inconspucucus comor viteline lucts conrect the vitellaria with the cotype iust jorsal to the ovary.

The excretory truiks are similar to those of the entire grcup of monostomes. The olajier is quite small, $48 u$ in secticn, moderately muscuiar, sucerficially triangular, with the excretory pore Scsterior. The excretory tube in the tail is vesicular at the

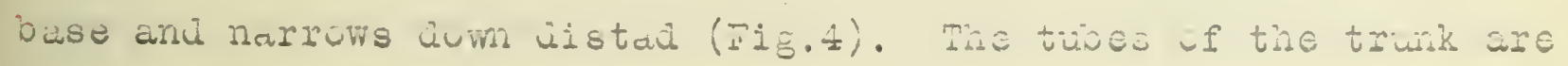
crowded with large excretory granules.

The digestive system is typically triclad, with ceca extending to the suodistal extrenity. They are filled with a iell, ani are crowded with granules imbesded in the jell. No pharyax has been observed. The oral sucker is directed vertrak. It is smali but powerful.

The parenchyna is fillea with cystogenous granules, incluaing 

the greater porticn of the content of the one-celled glands, rrobably of mesodermal origin ( $1 \mathrm{~g}$. 11). Between the cystogenous are the angular farenchymu cells, nore comonly krom as vesicular cells (Mlasenzellen), with processes extending to the irtegument and possibly furctioning in the capacity of secretory uncts for the tunica endogera.

The locomotor organs at the posteriorangles of the trunk are neither spiculate nur spinose. They possess no cement zlands. The tail has no central cair of glanj elements such as are found in bioculate cercariae of the monosteme uroun. However the nrdinary parenchyma cells of the tall of $\underline{C}$. celiucida are remarkably large and vesicular and suggest a glandular function (Fig.19).

Large isolated bands of transverse muscle fibars are present thruout the body just within the tunica eniogena. Longitulinal nuscles are not so large in the trunk as are the transverse series, but constitute the important muscle system of the tail. The transverse muscles of the tail frequently give a moniliform appearance to that organ, such as is described by Leity for Glenocercaria lucania $(1877)$.

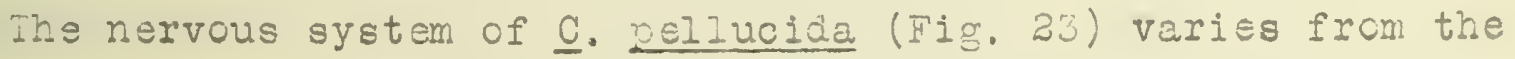
distome nervous system only in tis relation to pigmentation and the eye-spots. There are six anterior trunks and six costerior trunks arising from a paires brin center. liney constitute the dorsal, lateral and vertral nerve lines. These trunks are carefully followed by the melanoidin pigment fraction. The eye-scots receive innervation frcm the dorsal trunks; the pairea eyes are innervatei frow the costerior truins and the weviar sye from the fused oranch of the anterior dorsales. The optic nerve runs for- 

ward frcm. Its origin in the dorsalis anu enters the ifment cup from above, enuing in a sensory cell(Fie. 21$)$. The general anatomy and histclogy of this eye-spot is similar to that describei for all Turbellaria and Lonogenea. No frevicus account has been found for the structure of the eye-spot of the Digenea wich show its relation to the central nervous system.

Locomotion is brought about thru a cooperation of tha bcay musculature togetherwith the special functioning of the oral sucker and the postericr locomotor pockets. The ta1l serves as a swimming organ, with a ceculiarly rapid and nervous lashing.

Encystnient occurs as a final step in thelarval stage of the Iifs-istiry of the ganetic generation, in preparation for enteing the definiteve host. The process is rapid ani the mucoid cyst is secreted by the cystcgenous glands before the teil has been thrown off. This organ is freed from the oyst by the violent wriggling Which it produces. The cyst is spherical; it encloses the now cuiescent larva. The cuter portion of the cyst is an opaque mucold, which gives the cyst an appearance of a wite grain, about the size of a pin-nead. The larva now araits transfar to the deInitive host. 



\section{Cervaria koniuensis Fuust 1817}

cercaria knoalsnsis is a scecies of monostome ceicuril of thz bioculate type. The sceoies is more graceful than C. Dellicidiu. Its bodily cutour is most usuilly s atulate, while the lone tail reaches out far beink. The small arount of fignentatiun arour. the two eye-spots and the less usual fienentation along the rerve trunks caudai serve to inlicate the sune ficid differences loetwean the bioculate grous to which this form belongs and tine trioculate group.

Cercaria konadensis was found in Ivmnaea roxima Lea, ccllected from the Bitter Roct Fiver at Corvallis ifontana in votobex 1516. It occurred as an infection along with the larger species, $\underline{\text { c }}$ elI licija; 31.3 per cent of the snails examinel wers infeoted with this cercaria in the connective tissue betmeen the liver cea. The cercaria measures $0.4 \mathrm{~m}$. to $0.40 \mathrm{~m}$. in lengti and has a biliy wisth of $0.1 \mathrm{mil}$, to $0.16 \mathrm{~mm}$. (Fig. 25). Ine twil is of equal length under conitions of relaxation, but hay be extenaza so as to exceed. by far the bolily lenjth. At its oase it has a transverse aiameter of $30 \mu$ to $40 \mu$. The rosterior locorotor organs are not su cunsicuously lateral as thcse of C. cellucida(Fig.1). Considersin connection with the younger stage of C. celluciả ( pockets suggast an origin from the caudal pockets found in certain

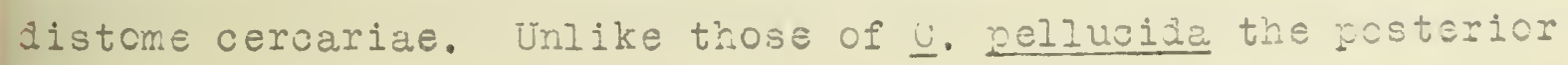
lcoomotor pockets of $\underline{C}$. kcnadensis are crovizei with acout ten êland cells surrcurirg the luren, cells prcbably of d secretury nature. $(F i \ldots .21)$

"ha partherita (Fig. 33 ) is a relatively snal, elongate rediz,

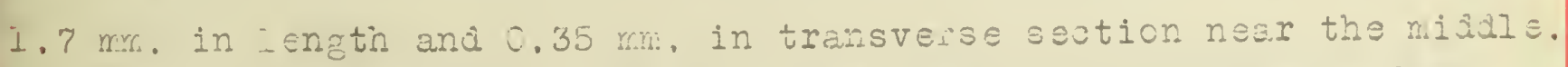
It is atteruately civtruneate, witn the costericr eni slo:ins dow 



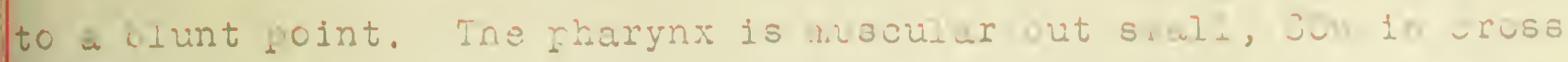

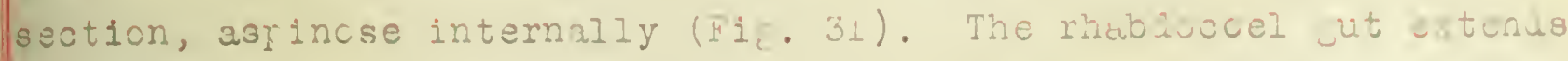
posteriad abiut three-fifthe the way. Tho posteriur om is ililed

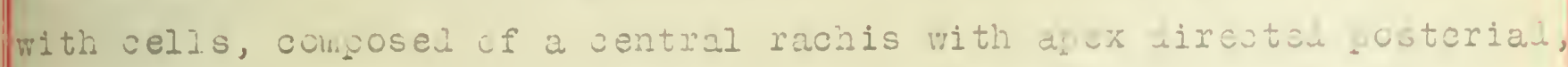
unj an outer cell complex of joolet cells ( racais cumprises the jeminal esitheliur, tia froliferating regicn of thich is situated subterminaly. Fron tibis eithelial nass the

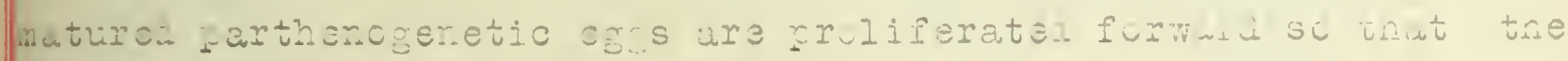
ext. balls come ti lie in the lumen oustericr te tho jut. sirileriy

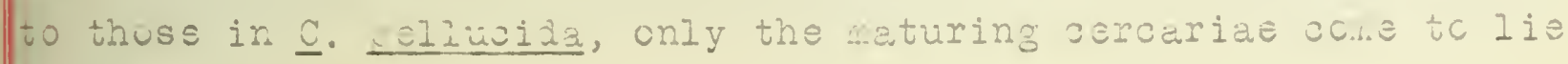
crouns tise vit.

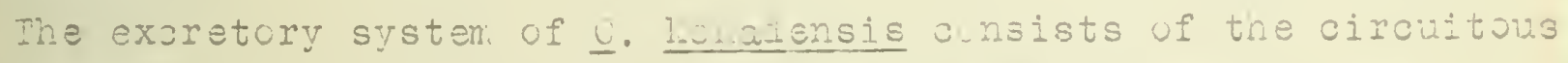
trurk syster, cpering posterivrly intu a now-ascilar vesioular blaber. This vesicle reasures liu to lru in wisth and liu to $15 u$

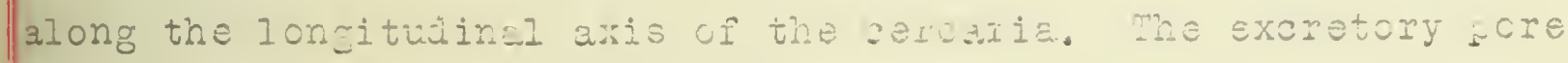
is iorsel, openirg fror the mialle of the vlaiver (Fig. zg).

The digestive system is of the isual triclad ty. istirict Eraryngal rasion.

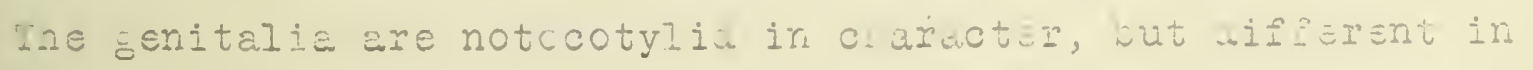
several features fror. those cf G. Elluei.ck. The cvary (Fig. 208) is skuli-cap s"alei, with a disinct Laurer's canal. A shcrt oviuet Is is into ths cotyce; after its juncticn with t... a viteline jucts,

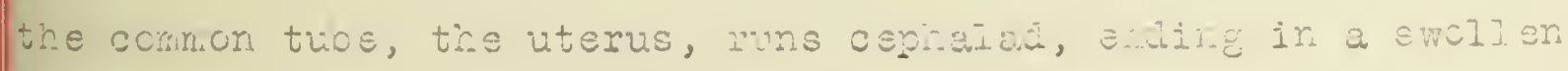
Vüina scme distance bahina the line ioiring tre cairea cya-epcts. He vitellaria consist uf a lunis serias cf fivi irner and tre

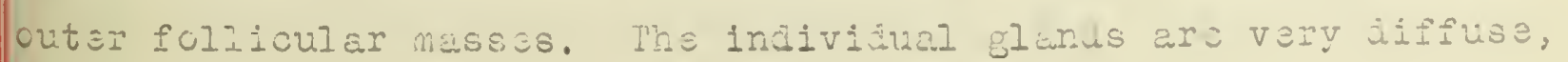
lanzitic.

The testes are small, lateral ani fustericr tu the vvery, with 



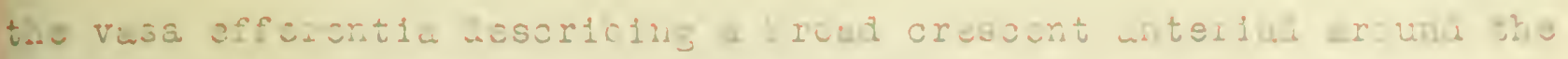

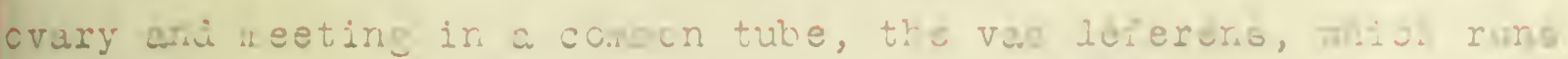
fcrwers to tie left na raraliel to tre uteria. It onjs ir w abclien sirus porich (

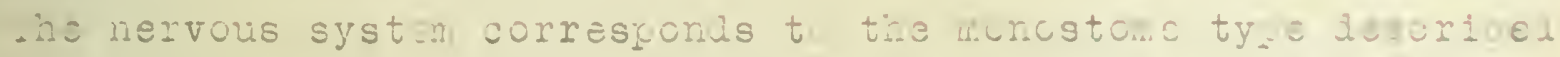
for $\mathrm{C}$. Ellioila, exvept that the iorsel trunk to tae silu picwent eys-spot is lacking.

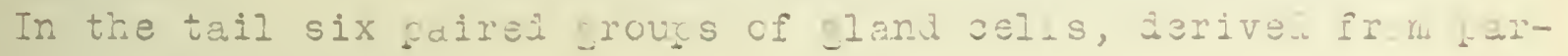
enohya, cocucy claces iust lateral to ti.e weitan cand uf the excrctcry system, each grau jove-tailirg intu tre cre next gruximal.

Encystment is brought arout by tre gouring out of tha contonts cf tis c cystcgencus celis anj suoseyiert Aecariation. 



\section{Holostonetu}

\section{Ceicuria flabslifornis Feust I3I7}

vercaria flcbollifornts is the first ierval holostc. iu to be Jesorices in detail for rorth incrica. Leily ras listed etracetyle tycica Diesing from Iymaea catascojium and Physa hetarostruba (180C), anj Rettger (1פgr) has menticned the larval tetricutyle in connection with a life-history study, but he has fail zu to ineltify the species.

Cercaria flabelliformis was found in thres collections of Fhysa gyrina Say, taken from the Bitter foct River ir the vicinity of Crrvali is Montana in jotcoer ISIS. Practically every snail frcm trese collections bors evidence of irfection with the carthenit of this scecies, altho only 1 i. F fercent of the snails exarines contained the tetracotyle. Tie mature cercaria has a lenth of 0.40 u. to $0.56 \mathrm{~mm}$, and a ridth of $0.44 \mathrm{~mm}$. It is about $0.8 \mathrm{~mm}$. thick. mile the antericr ens is not clesrly set off fron the postericr enz as is usual in holostomils, it does have tine suctorial cup wich includes all the ventral suctorial a aratus, ircluding among the rest the lateral suctcrial grooves. In tis young iarva trese laterel organs are iiscoidal (Hif. 11); in the watura tatracotyle they have become moxifiea into lateral lepeets (Fiz.40).

The larva is fcun in three conjitions. It may be maturing in the reaia; it may be free in the liver interstices; on it nay be encystej in the liver interstices. It is selion found free in the tissues.

The carthenita (:ig. 4 ) is a redia which measures $0 . \overline{3}$. ir length by $0.05 z \mathrm{~mm}$. in transverse section. The head is set cff from the trunk by a collar prominence, while in the posterior tinira 

of the body are found the "valking fcet", which grurule ventrolaterad and suckort the redia. The ecsterior end of the boty is

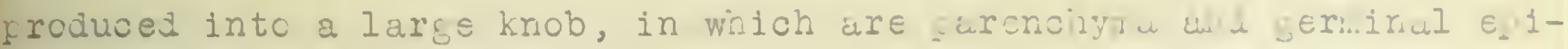
theliun celis. At the oral enj is a wide wusular organ. It 1s not iust clear whetrer it is a pharynx or an oral sucker. It is wocut

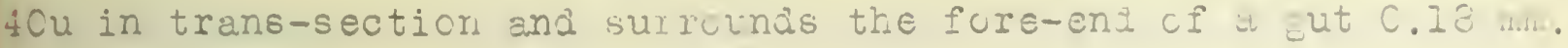
long. On tre ventral sile are two grouns cf salivary glanus, six cells to each groux, opening into the antericr recion of the gut

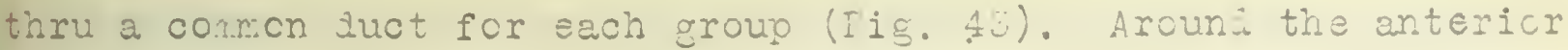
ard of the gut, just berind the musciar organ, is a nerve complex (Iis. 42), differertiateả into two ganglion masses on tia dorsul sid̄, four nerve trunks, and a circumintestinal comn issure. A birth-pore is lccated ventrol and silghtly sinistral. The wall of the corthenita is heavily covered with an integument of non-cellular meterial, beneath wich are Iuscle and parenchymd elements. Funning thru the carenchyma is a complex diamond pattern excretory systsm.

the geminal exithelium is lccalized at the posterior end of the redia. It offers an unusualy fine ocrorturity for stuiy of the maturation of the parthenogenetic ova. the detailed description of this maturation is found in thelsection on rempolosy, .20. The germ balis may differentiate into jaginter rediae and cercariae at the same time. These larvae are about equal in size as they develop, but the cercariae differentiate much more racialy than do the rediae so that the two are readily distinguished. Usually only three or four cercariae are fourd develcping at une time in the reaia, along with many daughter rexia. This fact seems to indicate that the animals have come to depend largely on 

agamic fropugation. The cercilie escart uru the urth-core and suon encyst in the free tissue of the host. Ihe alugnter re..1a is alrealy pro.ucing germ balls befcre it comes to take up a free existence outside the nother redia.

The internal systems of organs of vercaria ilabelliformis ire of corsiderable interest. Lowever, since they are lescrioes in detail in the respective seotions in the mornolosy divisicn of this pacer $(p, 57,71,92)$ trey will not be treated here.

Valuable conaorative data cn holostomid anatomy are fund by a comparison of Cercaria flabelificrmis with

\section{Tetracotyle pipieitis nov. spec.}

This scecies of las rval trematude was four in the masentery and pelicaritum of a large mumber of Rana Eiriers collactea in the vioinity uf chicago Illinois in liarch lsl\%. All of the frogs were more or less infected with this holcstume. The infection consisted if creany oval yellow cysts, either single or in vitiform clumos. Iach cyst consisted of nany lamellae, aru innermcst, a tough cyst wembane. The inrer merorane stains a deep brow with icdine in 70 ger cent athyl alcohol. The gross measurement of the cyst ranges from $0.5 \mathrm{~mm}$. to $0.76 \mathrm{~mm}$, in 1 esser diameter and $0.7 \mathrm{~mm}$, to $1.0 \mathrm{~mm}$. in greater diameter, while the inner merbrare is about $0.3 \mathrm{~mm}$. by $0.5 \mathrm{~mm}$. pithin the inner memorane is the larva, tightly cuiled at one end of the cavity, wile the remainder of the cyst, often two-thiras of the volume, is filled with acc rulations of Iarge excretcry grarules. Some of these granules have fused tu form single clurics as large as the larva.

When the lamellae and cyst membrane are teased oren and the larva is allowed to work its way out, the bjay becomes expandea 

tha flattenes. It then measures 0.5 . irlenth oy $(.07 \ldots$. ir trans-section (Fie. 47 ). The oral sucker is 75u in diameter. Ityics in un anterior cone of the body. Antero-lateral y romenus and the blunt posterior fortion of the body cive a lyrats outline to the frorm. The acetabulun, 80u in siameter, lies in a pians wiers the arterior and posterior portions of the body ioin, just within the suctorial pooket. The free ventral wall of this rocket is uften fuldeu packward so that it fits dom snugly against the bouy. At other times it bulges out so that the pocket cavity is a large ovoij atrium. A Einla lapcet is situated behind the acetabulum. The non-ruscular kccessory suctorial grocves corsist of long narrow silts, Jireated pbliquely inward toward tre acetabulum. There is no trace of a schincter in the region of the prinitive genital pore, injicating a complete atrochy of this organ accomparying the formation of a second genital pore at the postaior margin of the bojy. The entire worm is covered with minute syines, equally prominent anterior und posterior. Ths acethoulum is cromed with a ring of fusea syines. The lateral suctorial organs are surrcunaled by a berd of ciscrete scines imbeided in the tissues.

life worms examined were all fillsi with cxoratcry granules. A carsful stuiy of the larva shomed the main curse uf the exoretory trunks to appear as sno:n in fizure "̈. Ine reaian posteriur excrefory fore, slightly dorsal, communicates with the blacter wiah He-ges inpercentibly with the caired lateral trunis. These tuoss Rie just within the margins of the larva ana unite with ore anctier in a large trarsverse vessel at the anterior enj of the bciy, so tinat a complete circuit is formea. If a rent is croduced in the body foar the oral sucker, it is customary for the excretory grunules to 

be poured out there ruther than thru the naturai chaniel. $A$ tube from the lateral trunks crossis thru the ventral rocket mall at its anterior end. Tributary tubules, bisymmetrically arranged, empty into the main trunks, mostly at the anterior and posterior mirgins of the body.

the digestive tract is simole and inconspicucus. A small swelling within the oral sucker marks the pharynx, iust behina wioh is the esophagus. The cea barely clasp the unterior nargin cf tire ac etabuIum.

lie genital organs are reajily recognized as the holostome type (Fig. 47). They open posteriad. A smal spoerical ovary zies mexian. Dorsal to this is the ootype, into which come the short oviluct and the transverse vitelline ucts. The vitellaria are diffuse bands of large follicles extending from the anterior fece of the acetabulum to the posterior margin of the genital pouch. They lie strictly ventral. Two large oval testes lie to tie sides of the ivary, the one $\left(t_{z}\right)$ slichtly anterior to the other $\left(t_{I}\right)$. They have inaivilual lucts (efferentia) which reach tie gerital gouch an. fise into a common vas jeferens just before entering the genital pouch. This rouch is muscular, ovel in contour, with the transverse sianeter longer than the Ioneritusinal.

A survey of tise literature shows that only one tetrucotyle has been recorted for Aupibia, Tetracotyle cyistalina (-ua.), from the mesentery cysts in Fana temocraxia, R. esculanta, ufo icneus, B. viridis, and Vicera berus (Rudolvhi, 1819:380-33.3). The for-

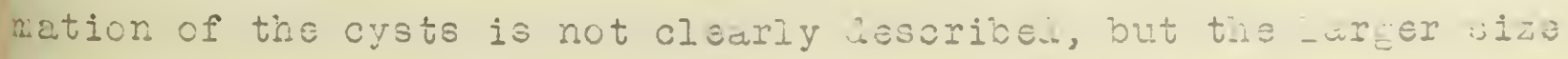
of the iuropean tetracotyle, togetier with its ovil contour, 3spin-

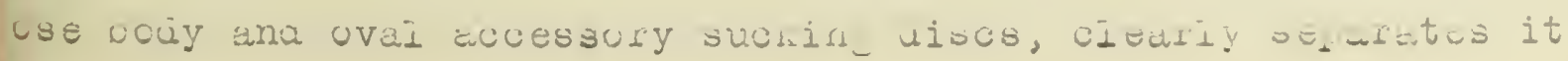





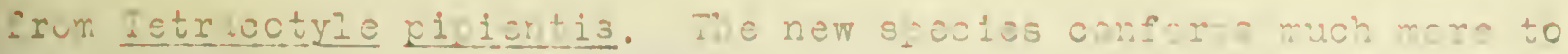

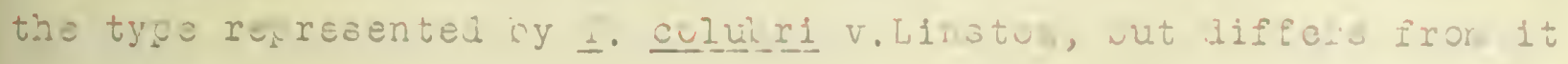
in the relative sizes of the ral and ventr l suokers, tire sijushé of the primitive genital fore, and the pusession of smal spines

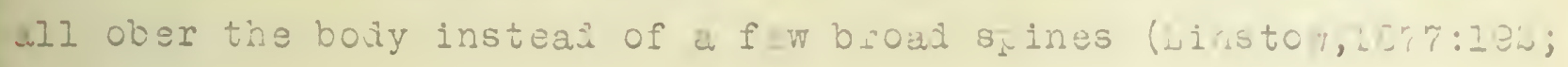
fig. $2 \hat{z})$.

. nile the excretory syster is one of the best eysters of or fant tc use in systenatic work with trematode lanvau, in the aissence if such data for otier tetracotyle lescribed, the date wetuily wiforded are sufficient in this case to iustify the establishrent of Tetracotyle pioientis as a aistinct speciss.

Ocservations on the anatomy of Ietracotyle ciaientis affurd an ovcortunity for compariscn with Cerearia fiabiliformis, the purasite of the Eitter Rout moluse, physe oyrina.

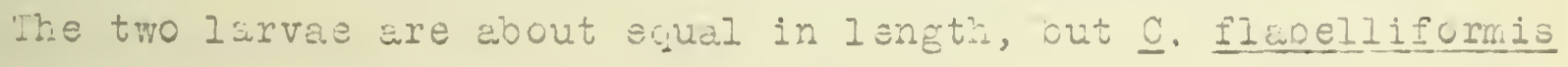
is cunsicerably the wiaer. The vidut region in $\mathrm{m}$. cirientis is in tre anterior region of the bojy; tre wisest portion of C. Elio-

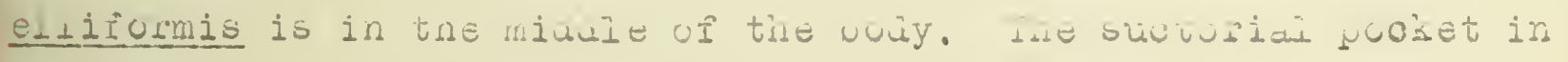
the Iorner species has grom over the ventral eurface so hat a true rocket is formed with the opening anterior; in the latter scecies the suctorial pocket is hemispherical with the orening ventral. The lateral accessory suctorial grooves in $T$. Lioientis are non-ruscular obligue slits; in $\underline{c}$. Ilabellifcrmis they wre at first oval decressicns which are molified later into a pair of lateral lapects. Tise crimitive genital ccre in . flibelliformis is rudimentary; in I. ripintis it is entirely lacking. Ons recognizes the horologies between the lateral excretory trunks of the tro speciss, altho the meaian trensversetrunk is most anterior in 



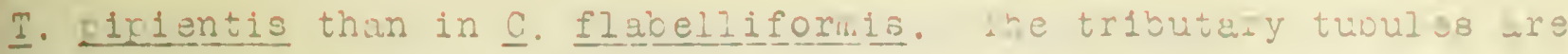

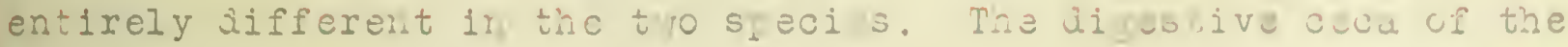
Bitter hout speciss conform to the family type in extenling woll into the losterior part of the bojy; those of I. ipientis are shrt and ruaimentery. The geritalia of the two siecies cooury the same relative position, altho indivilual varlatiuns if size end srave are evilent.

In cuncluding tha study of the tetracotyle larvae, euriasis must be placed on tre study of the maturation of the fartheno enetic u $v a$, and the data which show that the larvas do not develop into miraciaia, without the intercalation of parthenitae as (Eranles, 1891: 57a) maintains. This fact, previously recorald by the writer (1917), makes the morphological evianence complete in support cf tha view of true alternations of gametic and agamic generaticns among Holostonata. 



\section{vercaria ctyonosheilus Fiust 1917}

IhIs Diclostomulum is churuaterizel by un elongate ovate outIne, dorso-ventral flattening, with slight ventral concavity, anj a more or less distinct separation of body into arterior and.osterior porticns. In addition the group to which this worm dolongs lacks the lateral auxiliary sucking grouves wich ure ciaracteristic of the tetracotyle forms. Several species of Di, lostomulur have been well aescribed anj their excretury system beautifully traced by $v$. Nordmann (1832). Thses include the species E. volvens, D. cuticula, D. clavazum, anj D. brevicaudatum. Of the forms found in Ncrth America there have been recorded D. cuticula, D.

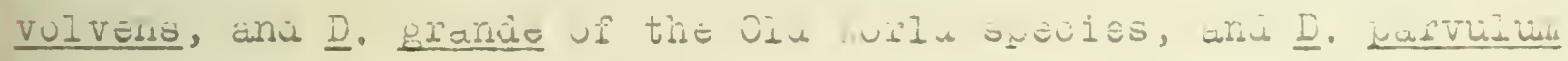
(Etaffori), new to North Anerica. However, as has been freviously suggested, nore of these Arerican recorals give sufficient asta to accurately distinuish the species.

The general cutline of the body of cercaria etychocheilus is such as to distinguish it readily from the desaribed speciss. Broady oblong ovoil in contour, with the anterlor half laminate and the posterior cortion fleshy, Cercaria might at first be confused with distome cercariae, Such a confusion is causea, further, by the aboreviated apceniculate portion of the larva, which, on extension into a caudal cone, may reach one-third of the bojy length, but on contraction barelt protruaes benind the anterior part of the boly. The concavity of tho anterior fart is found only in the fleshy region behind the acetabulum. Fer in this area is found the muscuiar complex comparable to the cupshapel suctorial arraratus of the tetracctyle.

The Diplostomulum (Fig. 4E) measuras $0.10 \mathrm{~mm}$. to $0.33 \mathrm{~mm}$. in 



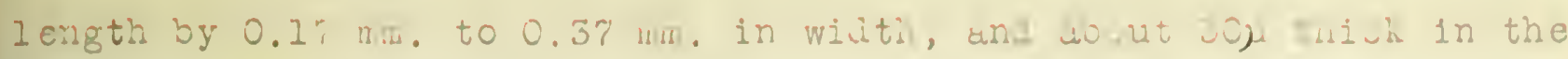
II siy portion of the o:y. The cial suaker la smoll iut go iarful, and is directed strictly anterlad. Jehind this ordi $x e 1 u$ the esochagus is enlarged into the phrynx, abut 4 uu in sacticn. Belind the pharynx is an equal cortion of the esoghar which is ncn-muscuar, costerior to which the cesa rise, s. reasing cut in to a broad furculum.

the acetakulum is lare and circular; it is situd i sowenhit costerior to the mialle of the boay. At times oz extrene contruct1on the acetabulum beccmes narrowed antero-oosteriad, with a transverse wrinking. This disc measures 7j; in Aimeter. The Frinitive genital core, situatea just in front of the acetabuluir, his lost its connection with the genital system and has becone mouified into a muscular sucking disc.

'The excretory, gentia.I and vervous systems have ween treatei on $\rho, 58,72,92$, as tyoes for tha heristome larva. Auvantage has been taken of $v$. Normanr's zbservations on Eicicstomuluir cuticula. E. Volvans, ans E. clavatur, and of Dlanchard's work on Eemistomum

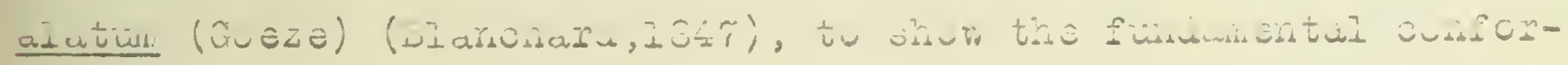
mities and differences of tine excutcry systers of the Ihe nervous system (Fig. 53) is worked out in this facer for tha sirst time ir the Holostomata. The genitenia boar a funiamertal resemblance to those of the adult species, as lescribed by jiaties ( oreans. Wis aifference may be accounted for in part by the immaturity o: scre of the olyans, but there are undouioialy specific

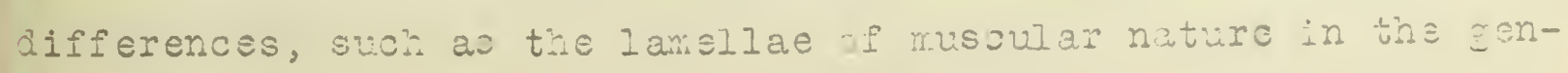

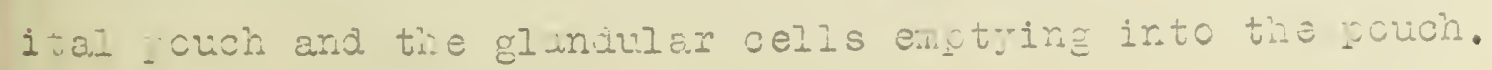



Vevertreless, when $\mathrm{ll}$ if the factora ave been cursiusru, the nost striking feature of the larva is the w...revisted w yruiculate gortion.

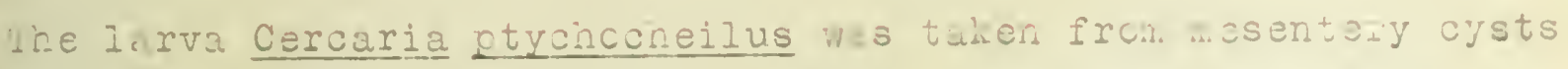

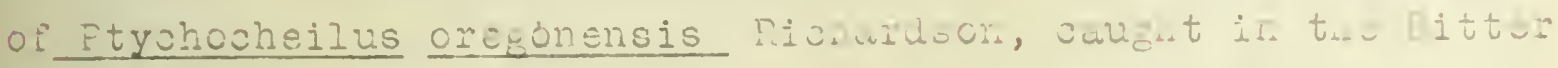
rot river in iril 1925 in the vicinity 6 etevensvilie wu Cariton Ritana. Inclisals of cysts wars found. Ihe oyuts are

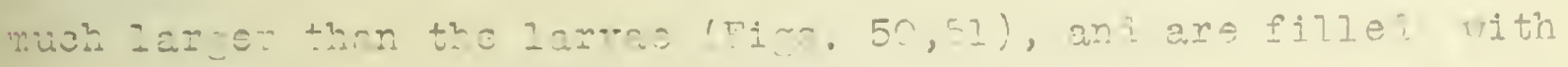

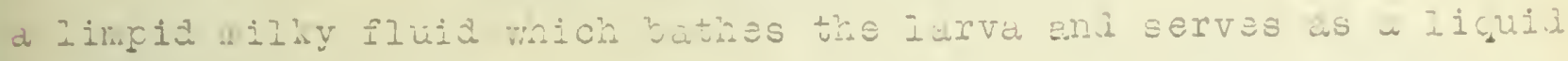
cushicn. Whe syst is wlurg, and flettened. It is ounicsed ci

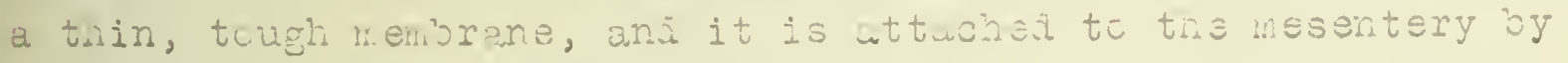
a siscoid innulus ir. the nidile n une of the fluttenei siues. within the cyst the worm wciks arcunu ari grors, su that it ou..s? to fill the oyst in later life. Au frequent intervals tnere is extruje, fion. the excretony tajier y considejable quartity of granules which rile vp at the costerior eri of the larva witin

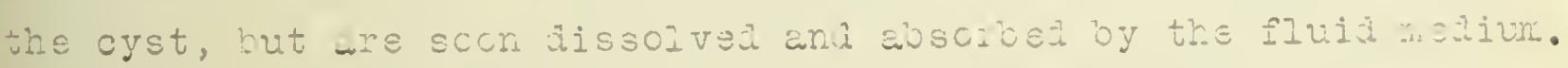

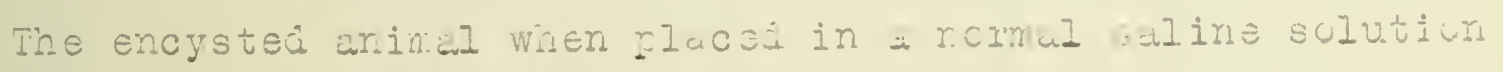
sccn ircresses its activity and bursts the oyst. wis ischt usualy cocurs at cne eru of tre nembrane. The larva tren crawis ut with a ": easuring w. riu. novenent". After severaz licurs uI wotivity

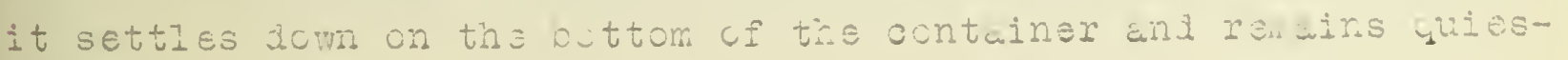

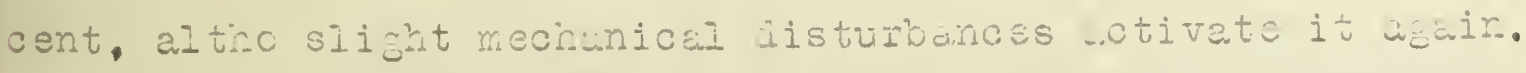

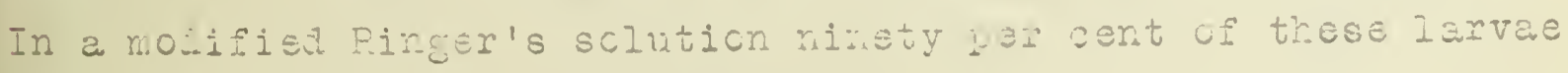

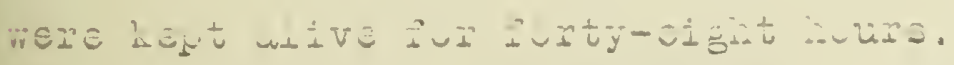

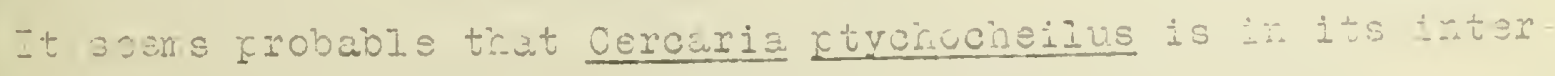
i. isat incst. 



\section{$E: s t z \cdot=t u$}

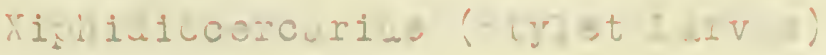

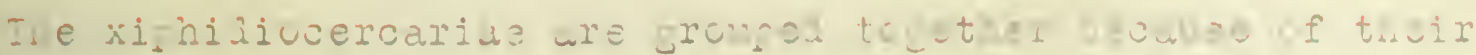

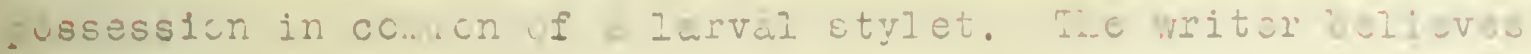

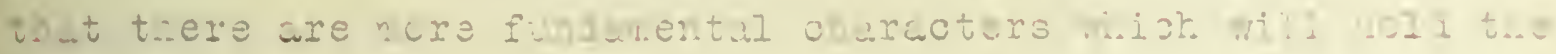
gou: together, banely the feat res of the cenital and exerztury systens.

\section{iercoin orenta parst 191?}

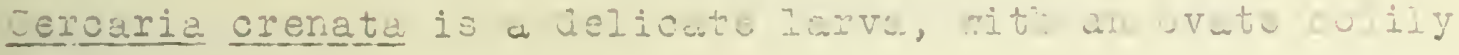

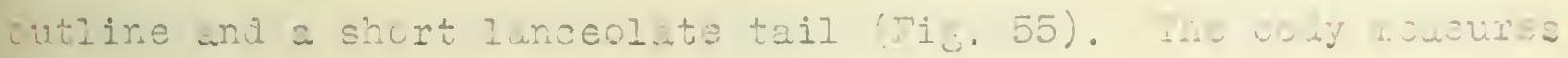

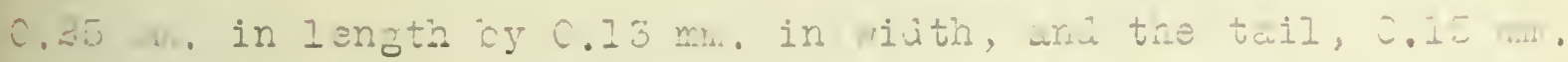
tc $0.13 \mathrm{rm}$. in length by 20 , to 30 j it the ouse. Ine entixo boty.

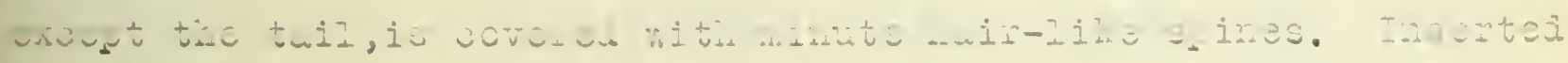

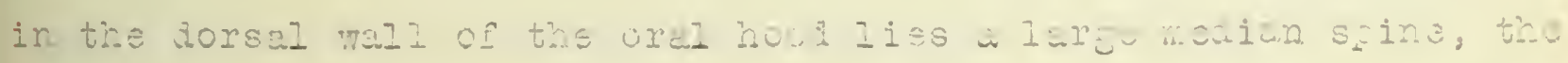

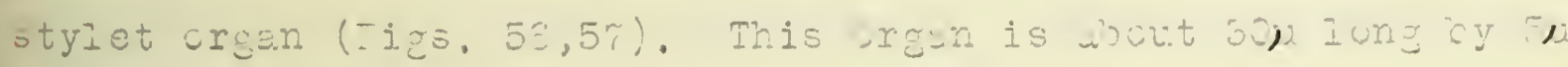
in wisth at its baso. It has tho general shepe of i yuill - on, itir reinforoenents at its base ent also in the istal forticn tonara the ecuto foint. Tha ilstul thirs of the stylet is icent ventras for about ac legress. There wre two gromences ir the anteriar cortion of the crgun, one where the shaft icins the guill and a less proninent one half-way between this point ari the quill roint.

"he oral sucker is relatively Iaree, z0) in ditueter, wilie twe acatabulur, situated three-fifths the way from the anterior and, neasuras just half that diareter. The tail is inserted ir tine costerior cuulal pooket which hwo no sinous proiections.

cercaria crenata was icuni in large numoers in 13.6 per cent of Lyrrace Mcxira Lea, taken from the springs at Fort Misscula 



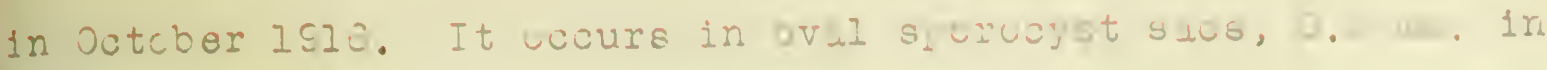

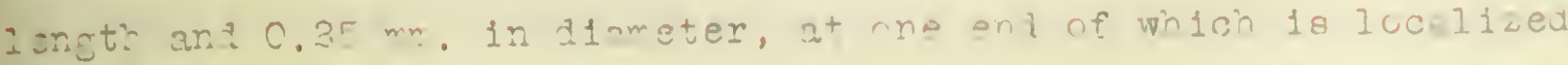
the germinal epithelius, und from wich the furthencegnetid ovw wl proliferated. Inly aera riae huve been funut to wovelop witnin the sporocysts.

Then the corcaria is nature it brakks thru tha rali of the s:crcoyst and swims thru the surrounding mediun. The tail is retained for a consilerable tims, ani encystrent is slow. This sems to indicate a corsiderable period cf fres-smining iffe.

the interral structurs of ciscaria crenata is such as to distirguish it reasily from the other stylet cercariae.

Ihe excretory systen is characterized costeriorly by a sub-

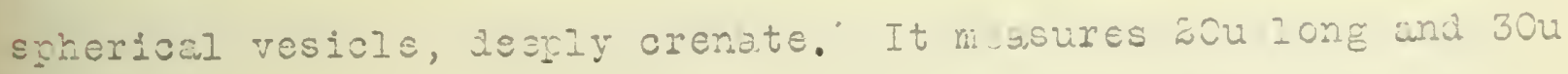
nice. Anterior to ths blabuer a bicorrute trunk enctias into the vesicle thru a ccrubor median tubs. The horns of the U are wibly separated. At the claoe where each main leteral tums forvard there is aiven off a sirll dendritio tioule, îrected costeriad. Scme diatance sine

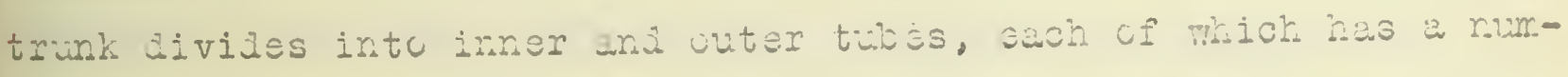
ber of dendritions and capiliaries onterior. The main tube of the tall is median, with no crominent tublues.

The digestive system consists of an escriagus provided with a pharynx for most of its way, an behind the pharynx, a typical furculum sxtending to the posterior plane of tis acetabulum.

The salivary-mucin glandsin $\underline{C}$. crenata are of a unique type. An outer series of eight small vesicular cells, witis a comon

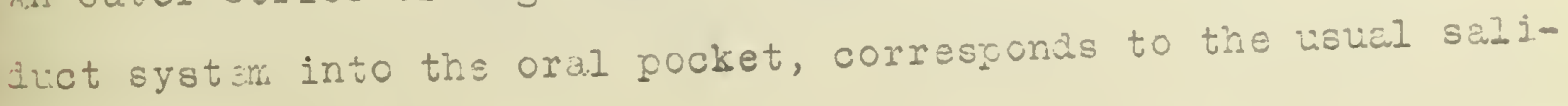
vary-nucin glani system cf the cercarias. These finas are reai- 

lly mase out in the living worm. An inner series uf fivs celis, two of which are iust bshind the charynx anci triee bohind the dectuicuIum, empty thru a confon auct systen: into the crul fccket. "This series is not scen in the living larva, but in stainel specinens the colls of this series show small vesicular nuclei with deerly stalning cytoplasm and numerous chromopilic granuies. Fris inner series crobably consists of a type of sulivary gland different l. istoldoiculiy and sugueste w corres.chingly different function.

ihe genital cell masses are crominent and are well differentiated early in develocment. Their structure and position are indicated in figure 59. Fosterior to the acetabulum and sian Iiss the ovary,; to the anterior ant left lies Laurer's canal. the uterus is characterized by a double coil, wich enis in a wolerate sized vagina, just anterior to the acetacuirm. The vitellaria are extremely limited in amount and distribution. Fhree choras lie in a transverse plane just posterior to the ovary and meet the oviduot at the ootyoe. Ihe large flask-siciped testes lie benind the cvary. This system oi genitalia suggests the Plagiorchinas arangenent. The distribution of viteliaria are similar to those describet by Pcirier for Plariorchis sauromates $(1886: 01 . \overline{2})$. 



\section{Cercaria indalusa Faust 1917.}

A stylet cercaria characterized by a nultirlicity of glunas has received the name f Cercaria olsnulcsa. It is scwewhat larger tran $\mathrm{C}$. crenata, is more oblcne ovate, and is a wich rore cotive larva (Fig. 60). The boay measures 0.45 . inlength and c.2 m. in wiath. The tail is slightly shorter than the Lody, 0.35 $m$. in length, by $50 \mu$ to $60 \mu$ in section at the oase. The tail is set within the caudal pocket. This rocket is grovidew with a rair of locomotor grooves, in which are set a number uf stiff soines. Below the insertion of the tail is a smail lappet (Hig. 63), Erovided with three snines Airected nosteriad. A muccia secretion is present in the sinuses of the pocket, lateral to the base cI the tail.

The stylet organ measures $33 \mu$ in $\lambda$ ength by $5 \mu$ in widh at the base of the shank. It is reinfcrced all thru, but especially at the base of the shank, and thruout the quill. The point of the stylet is biunt. The stylet, as well as the entire bojy, is very alicate, and is shattered by the slightest cressure of the cover slip. The oral sucker is directer downarif it reasures $86 \mu$ in diameter, wile the acetabulum, in the midise of the ventral side, is smalier, with a diameter of $6 \mathrm{~km}$.

The cercaria was found in the liver tissues of Physa Jrina Say from the Bitter Root Fiver in the vicinity of Eamizton uicntana in october 1916. Forty per cent of the physas examined were infecte. With the parasite. The cercaria develops within a very simcle sporocyst, which has a length of $0.34 \mathrm{~mm}$, ant a wiath of $0.17 \mathrm{rm}$. (Fig. 67). The wall of the sporocyst is delicate, consistine of a single Iuyer of very trin ejicemal ceils, with no 



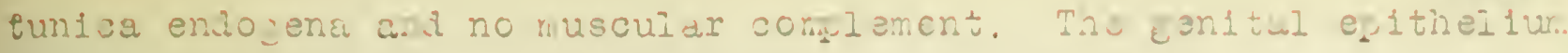

Is localizel at one ent, und fror this a fer cersariaz wre levelce-

ed at one time.

ine excretory systel uI Cercaria landulosd presente somo interseting features. The blatue is flattencl, truncuta, aru is subterminal insteai af terminal. A narrow cunal conruricutes with

the excretory ore which is nealan costeriur. The four urglys s the blatier are nusvular. Then the olajier is emitisi tinese corrers lie close together, so that ths cavity f the bluhuer is smil. Then by the exransion of tine blatier tin organ is filied from tire trunks (Figo. 34,65). Two vesicular cornua eupty into the blalaer. Zach cornu is directed live.. a. anj slightly anterial, it soon constrists to form the lateral tuoe. Iis comon tube divides soon to form the costericr tubule ard the antericr tube. Ine anterior vessei uivices in the region of the acetabulum to form a trifurcate system. Just beind the region of this iivision there is a small vesicular sweling where granules cf the syster accurulate. The excretory system in the tail consists of the comon meulan vessel and several tributaries.

The digestive system is characterized by an abunance of glands. so that the entire tract is surrounde vith iland celis. A siul pharynx surrcunds the escrhagus near the anterior end of the tube. The esophagus extends to the oreacetabuiar region, at which risce it ofrks to form short furcae which barely clasp the anterior end of the acetabulum. Along this entire course there aromany gand cells. in clusters, but espeoially abundant in the prarynx region. Their relation to the charrnx and nerve ganglia is shom in zicure 72 . The individual glans cell is ovate, with a short neok. Tha cytoclasm is chromophilous. There is no recognizable duot-connection 

thru the myoblasts of tire pharymx. Tre nuclel f th se celle are large and studued with granules.

In contrast to the grape-like clusters of glenz cells surrauning the entire $l i g e s t i v e ~ t r a c t$ are the right and left paired lind groups of the salivary-uruin tyfe. They consist of nine large cells to each group, usually situated in tio acetabular region, iut cupable of extension, so that they may lie as far caulau as the bluker (Fig. 6z). Figures $7 j$ and 74 shom sections rassing thru the wrtesiot tip of the excretory vesicle. In each of these a right and $a$ left gland is visible. In these frlands not only is the rucleus granular, but the cytoplasm is densely grarular, the granules bei ig

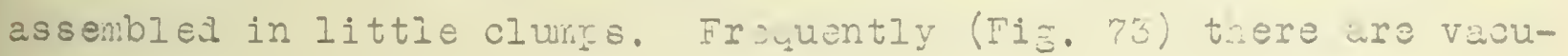
oles vithin the cytoplasm.

The genitalia are recresented by cell masses wich show clearly the location of the mature organs, but as yet sicn Iittie differentiation (Fig. 33). Ovary, Lurer's canal, vigina, uterus, - all are recognizex in the nijacetabular region, with vitalline follicles extending from the oral aperture to the posterior enz. They are divided into anterior and posterior portions. wo testes are yet to be founs. Whe genitalia as a whole injicate Placiorinid relationshix.

Conspicuous thruout the boly are the large buniles of Iongituainal muscle fioers. They are scattered thwucut the parenchyma at the anterior end (Fig. ra), wile they are much larger and more concentrated laterad in the region of the acetabulur. Still further caudad they become fewer and less conspicucus(Fis. 74 ). the crvis syatem has been iescribex in jetail on 2.85 . lihis cercaria lives a free-swiming existence for only a short 

time. Wnen ilsed in watch-zlass in tw water, it bon dros 1 its tail, preparatory to encystment. The tail is kelful in loccmotion, yet after deculation this syecies is nore active and avle t, cover considerably more ground than most other species with the ald of the tail. This movement is due in no small measurs to the spines of the locomotor grocves of the caudal pockets. Ifter moving dout for a little whice tire cercaria settles dow and pours ut an abunlance of slime within wialoh it coils up and becones quiescent until a transfer to tho new host is effectei. 



\section{vercaria dionana Faust 191 ?}

Cercaria lianhana is closely relatel to $\underline{C}$. linduloaa. fnen contracted, it is broally cvate (Fig. re), but on extension it assures an elongate ovoid contur (Fig.73). The measurement of the bojy when at rest is $0.2 \mathrm{~mm}$. to $0.23 \mathrm{~mm}$. in lenetr by $0.2 \mathrm{mb}$. to $0.12 \mathrm{mr}$. in wath. Linder pressure of a cover slis the intenal organs are beautifully worked out and tre delicate hist of the rarenchyma in which they are irbejled sugests the term "uiaphancus". The tail is brcady icnosolats, $0.15 \mathrm{~mm}$. in leigth by $0.04 \mathrm{~mm}$. et the base. It is inserted into a caudal pocket provided with scinose locomotor zocket groutss. The spines are ferr in number (s to 10) and wall developed. They are directed meso-cautad. As in $\underline{C}$. aluntUiosa the two sinuses of the introverted rocket are thiokenes by a ...licoi larination. The acetabulur is situated in the riajle of the ventral side; it has a dianeter of about 32u. The larger and more powarfil oral sucker has a diameter of 4tj. Tha stylet organ (ㅍig. $77)$ is a delicate but firm quill of 39 length and 5x with at tre base of the shank. It is entirely withcut any reinforcement in the ragion of the shank byt has thin ventral platos at the iunction of the shank anj quill, wille inserted in the quill point, directed posteriad, is a minute s.ina, $5 \mu$ long ani $0.5 i$ in aimeter.

Cercaria diarhana was founs in the Iiver tissues of Lymnaca croxima in the Bltter Root River near Corvaliis in octooer 1913. ihe infection was heavy. Lhe cercaria divelocs in an oblong sporocyst (Fig.79), frequently iram out or contortad at cne end (Fig. 8C). The uni gue fature of the scorocyst is, that tise geriniral enithelium is not localized, ans consequently germ balis ma bs derives from any porticn of the bciy. It is a watter cf consiaser- 



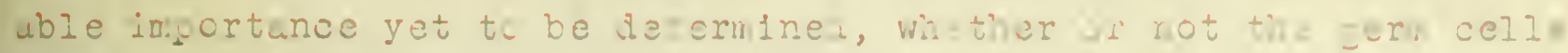
arise parthenozeneticaly. Iis ty.c of gernialigrolucinn reoresents a structural sim. licity provicusly lot rovudei fur tre sporocyst.

side excretury systom differs srom that of cthos stylet vararia ... anly in the shape of the blawte. and ci the essential tubes. lne blatuer is small, heavily muscular, fluttensa unterv- cotoriau.

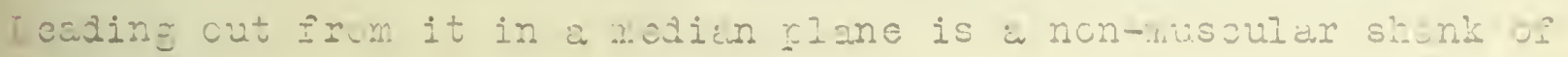
some length, wich opens into two cornua some aistance in front of the blather. Caviai these comia are vesioular, out further

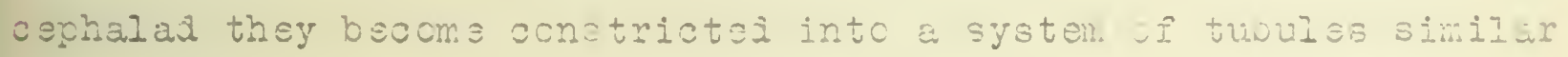

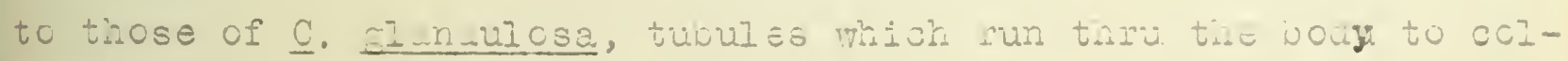
loat the exarctory wastes.

Thejigestive system consists of a long esochagus, with ghenyx

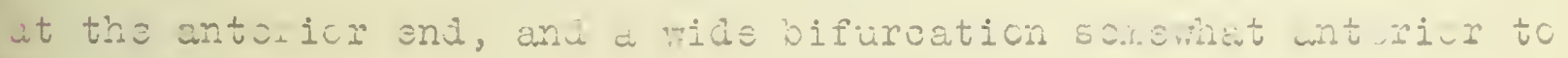
tre acetabulum. Tre sntire jigostiva trat is very ittanuate in

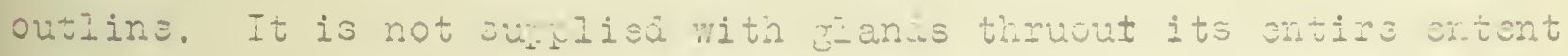
out aes an even nore wbundant suprly than C. Inndulosa in tho

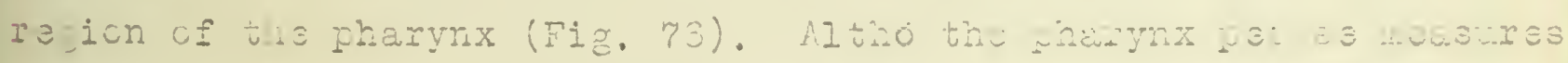

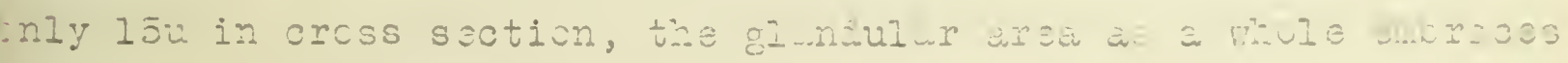

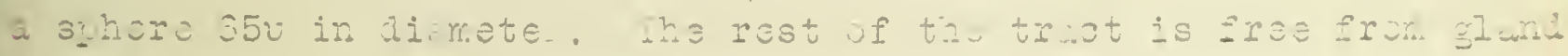

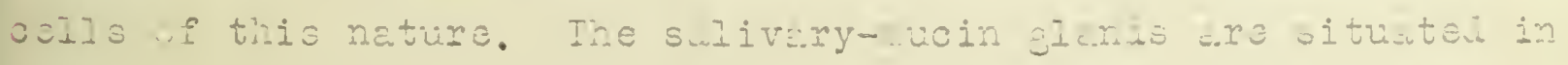

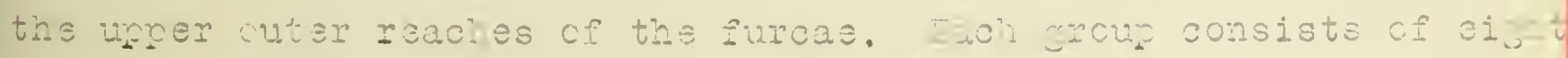

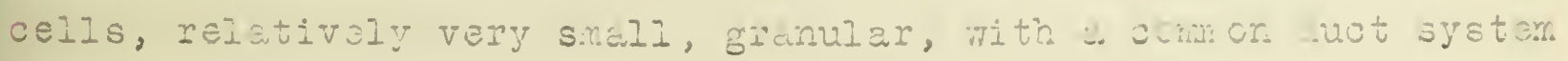
ontros inco tha cral pocket.

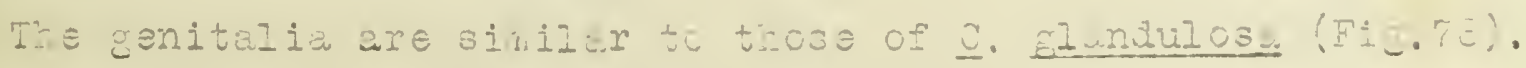

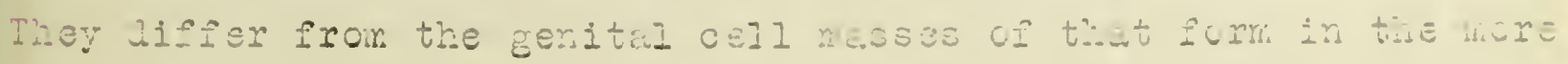
Ii ited vitelderiag and tre more cons, icucus wurer's own. Inis 



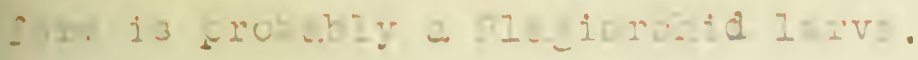

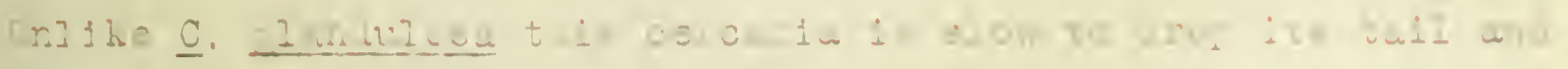

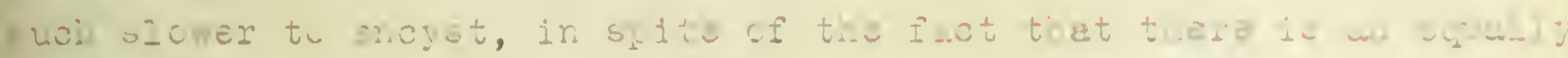

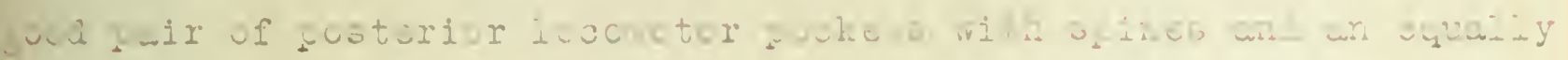

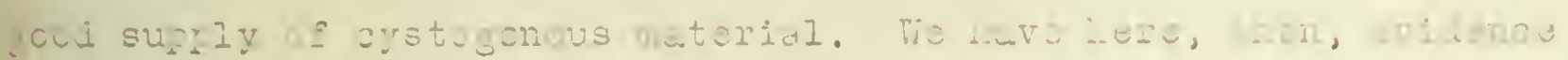

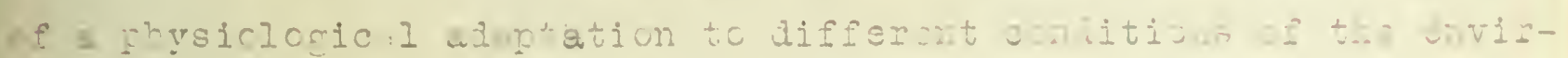

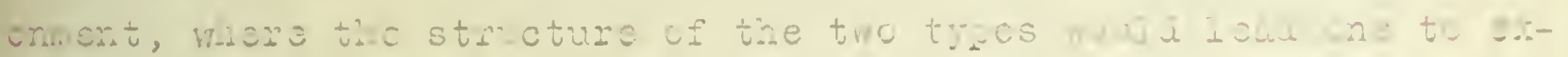
- oct sirilar htoits ani rewotions. 



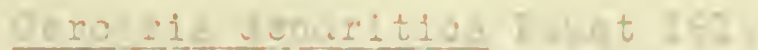

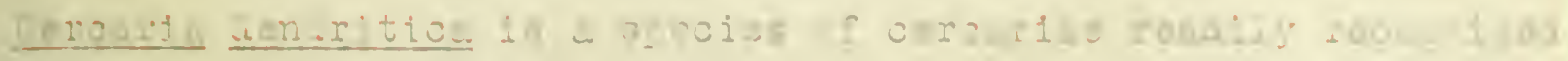

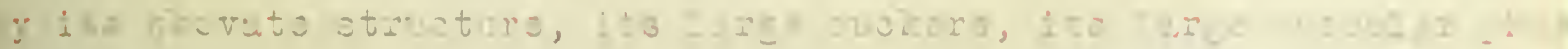

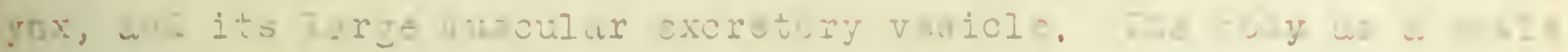

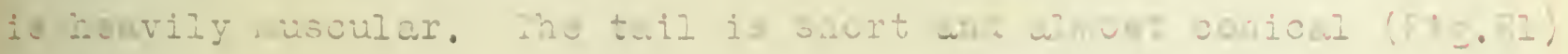

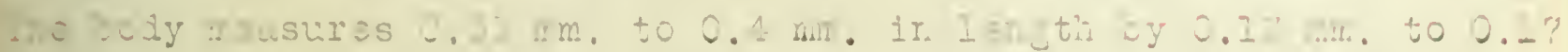

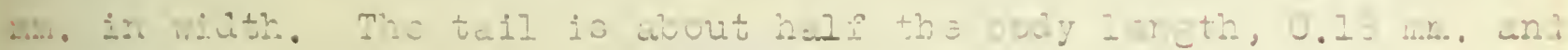

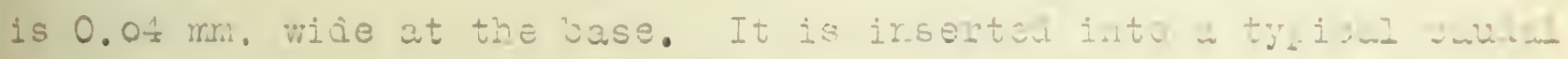

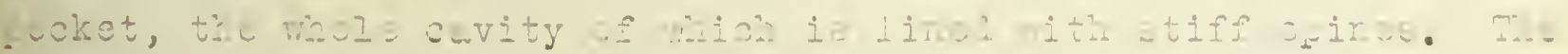

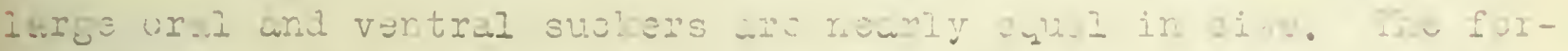

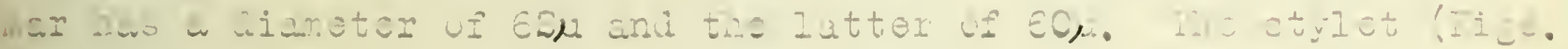

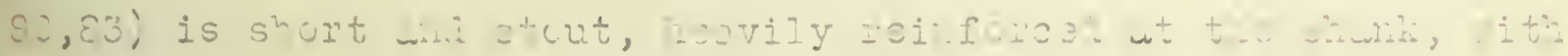

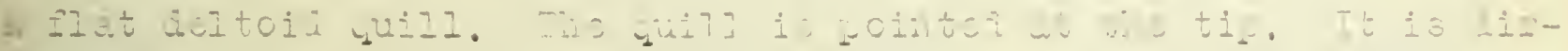

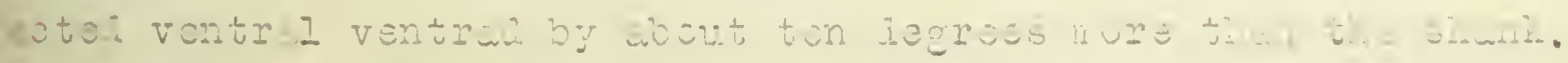

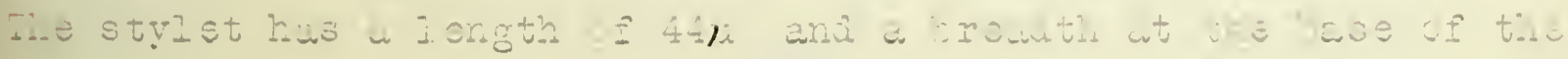
shark of 14 is.

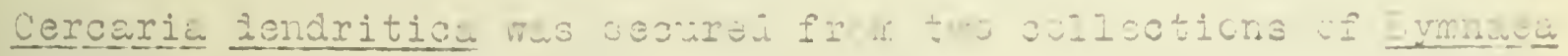
arcxima taken from the chere sloughs au Fort Misscula fä zotuier 1916. The infecticn was in the liver incerstives. The furthenitw (Figs. 8r-89) is a well develcreal srorocyst, with ar wteshment ilso, but without any indicaticn of s licestive tract. It sachs to arnroach a raila more nearly in its structure tian any otwer joscriber sporvoyst. The sporocyst is ruscular und hevily covercud

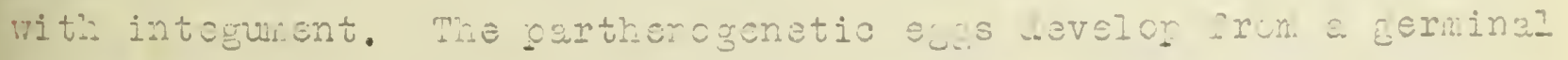
epithelium situated at the antipodal end frok tho ilso. The ctagis of cleavaga are clearly maje out from tha stuity uf t..e germ cells proliferating from the geminal ecitheliun (Fig.80). This layer is closely pressod agairst the einermis. As tho cella weture trey 

incruase in size. The increase continuse thruent twe obouver, ac that a tr ree-cell stare is larper tisn w one-cell stare, cha w no:ula is larger than a fiva-cell stage. This outiriot growth of the embryo is accounted for by the environiant of the gum bell sinoe it is lying in a modium of nourishment which bitsos ts a wrcoyst. This is a special case of ovovivifary, whore tha grouth stimuits is reactes to innediataly. The gorm bell wttains a consiaeraile size heare it berins to jifferentiute, withu eiboly has occurred scon after the morule stuze his been rached. the animal is mature before it breaks thru the wall of th syorccyst anc. swims cut into the inter-cesar spaces.

The larva has an interesting excretory systen (Fig. 81). Mn inisense scriercid bladier, somewhat crenate, ofens iorso-posteriau thru a small core. Anterior it receives the contents oi two large muscular corrua thru a conion opaning. Thase connu axtend listeraj to the extreme mirgin of the mimsi. At the outsids of swoh, at the margin of the worm, arise three tubes, cne uircoted fosteriad and an inner ana cuter on e each directec snterida. Fhe cupillariez are brush-like. The cauial tube is a maian canal withcut any prominent tubulss.

The alimentary system consists of a pharysx spineter of fibrous structure early in the sevelopment of the $\pi 0 \mathrm{rm}$. It has a wasth of $30 x$ and a length in secticn of 33j. A short, attenuate soshagus ocens posterial into two vestigial furcae. Anterior and latsmal to the acetabulum are the salivary-mucin glanis, eight to each rou. They are mojerately Jaræe (Fig. 85), and emty tiru cinron üuct systems into the oral pocket.

Whe conspicucus features of the genitalia(Fig. S6) are the lenge 

swoljen vagins, and the froninent Laurer' cunal, the litter extending out on the left side of the acstabulum under 1ts goterion margin. In the mik-arca, just behind the acetabulum, wre two small Eyiform testes. The viteliine glands exten from the cxtrens unterior margin of the worm to the extrene ccsterlor ond; hey ars attenuate, starcely branching sexpentine cherds, corrosei of a long anterior and a short po teriox purtion. Tue viteline ucts run in from the rostero-lateral reoions to the octype, which is iust anterior to the testes. Ihis type is also sugrestive of Placiorchici relationships.

Soon after the cercaria is set free into the water, it jru:s 1ts tall. Almost before the observer is aware it secretes a thin membrane from the aburarce of cystcgencus material containea in the large oyst cells which pack the parenchyma of the worm. The oval cyst with the worm coilew ur irside is shom in figure 84. This type of cyst offers only a temporary lodzement for the cercaria, and it is eviant that the worm must reach the jefinitive host scon if the infection is tc ba successful. 



\section{Cercar1a ricrcharyx Faust 1017.}

Cercaria nicroharynx is a ninutc lerva of tae xishiliocorouriu arcup, cval in contour, with snall clavate ta1l (Fig.95). The boty is cuvered with ninute s inesarranged in dimont pattern, prog:eskively less prominenttoward the caudal end. The sines are groburiy constant characters of tha adult as well as of the larva, since the entire trunk is well suppied with these spines while the tail is naked. The body measures $0.18 \mathrm{~mm}$, in iength and $0.09 \mathrm{~mm}$, in vilth. the tail is $0.14 \mathrm{mr}$. Iong and $0.03 \mathrm{~mm}$. at the base. It is inserted into a culudal pocket provided with a group of spines on the latersl lappets ventral to the tail. The oral suoker is large for the bojily size, $35 \mu$ in diameter, while the acetaoulur is slightly smiler, 30 in diameter. Inserted in the hood of the oral sucker is the stylet organ (Figs. 91,92$), 34 u$ Iing and $5 u$ to $6 u$ in breadth along the shaft. The organ is reinforced all around and has a valum stretched across the ventral surface of the quill.

The cercuria was secured from the infected liver tissues of a large number of Limnaea prcxima, taken from tha Futtlesnake Cresk, irissouia, in liovember 1916. The cercariae develor in oval irregular sporocysts, measuring $0.24 \mathrm{~mm}$. along the long axis and $0.18 \mathrm{~mm}$. along the short axis(Fig. 94). The boty well of the sporocyst consists of a single leyer of eol emal cells, between which are found numerous excretcry granules, lying in irregular grooved channels. There is no localization of the germinal sithelium, so that germ balls arise from all portions of the body wall and, when mature, break out into the body lumen. Irot only do the cercariae develop to maturity in the sporocyst, but in some cases they brop their tails and encyst in the scorocyst (Fic. 35 ). This must 

be interpreted to nean that the larvul bost, the snciz, in the foct of the definitive hest, since no free-living stuce is cumoniy

founs. In case the cercaris is pressed wut of the sporocyst before encystnent, it swims about for a very bilaf perivd, then ircos the tail and encysts.

Lhe excretory syster. consists of a subsherical vesicle und bellows-shaped currua, which open into tha vesicle thru a cumon cylinder. The three usual tubes of the excretory system ore resent, the single posterior and the two antrior onss. The twil tube is single, meian, with a few incunsicuous lateral tributaries. Whe cornua are filled with excretory fluids; they are lined with cells (Fig. 98).

The aigestive system. consists of the very minute pharynx in the mid-region of the esorhacus, and two vesicular furcae corsizerably anterior to the acetabulum. No glands oocur in the gharynx cr furcal regions, but in the prepharynx regicn, iust within the wral aperturs, is a band of abcut fifty goblet celis of a glandular nature. The salivary-micin glands ere fiund at tre sides of the ocetainum. They consist of eight cells for each grour. They are relatively large, vesicular, and have common ducts opening into the oral pocket. Large muscle elements are scatterea thruout the arenchym, in auticn to the ususl trinsverse ark longituinal systens iust within the integuxent (Fi@. $9 \%, 33)$.

Whe genitalia (Fig. es) consist of a crobinent vaetna, a well ¿efined Laurer's canal, and a group of massal organs in the vicinity cf the votype. There are, in alzition, the yolk follicles, distrioLited over a wide range of the jorsal side uf the arimal. The follicles are closely messed to etrer. Inis species suijests, too, the Plagicrohia genital system. 



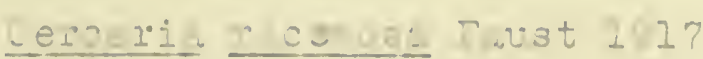

Cercaria rwoensa bezonzs to that sicup uf stylet cercariue ustally designated as cerariae ornetae, iy viftia of tieir pussosion of a fin-fold structure to the tril. chis this se erution : ay be ccncomitant with a deeper, nore Lundusentul ifficrand cf tyre, it is well to bear ir minj that fir-folds cour in ther sroups, as in the worostome, Cercoria 10.hocerci (Filizei, I.j7: 5; fig.3), the cohircstona larva, jercarid achisatuides IiI. (ud ial-

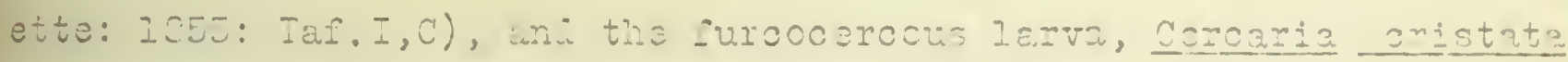
(La VaIєtte, 1855: Iaf. II,K). It muy be louken on as a mo-ification of the caudal organ for swiming.

ifo bouy of cercania racemose is elongate cvila, incusuring C.39 $\mathrm{m}$. in length by $0.11 \mathrm{~mm}$. in visth (Fig. 100). It is characteristically broadest inst ansai cf tire acetabuinu. The tail consisto of a centril lanceolate region wa a lateril ruffled fringe, win is

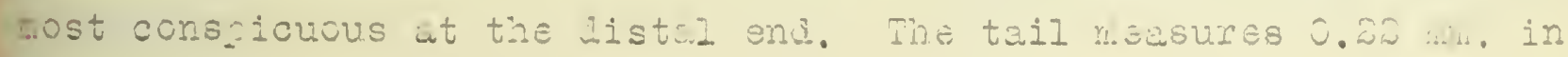
length and $0.04 \mathrm{mi}$. in with at the base. It is inseated into twe fosturicr extreuity of the trumk, wltho there ure no laterul sinus ss to be found hara. Tre acetabulum is silghtly cuudal tc the milazo

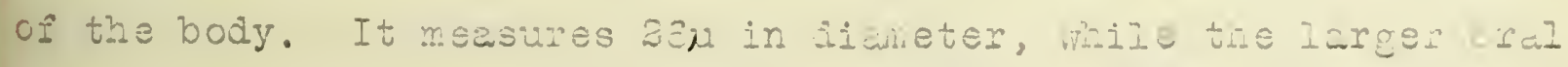
sucker his a hizreter of 30u. Whe stjlet orgar ( is Aelicately attenuate, with a reinforces … It İ u M I che and ibout 5u wile at tile base.

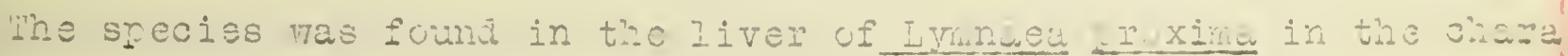
slough of the Bitter noot Fiver at Font Missoula in October 1813.

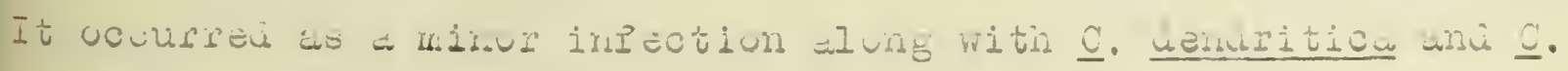
arocilima. The partienita is an irreguidupoly, chil s,crooyst ajout $0.35 \mathrm{~m}$. IonE añ $0.35 \mathrm{~mm}$ thick (Figo. 104, 105). 



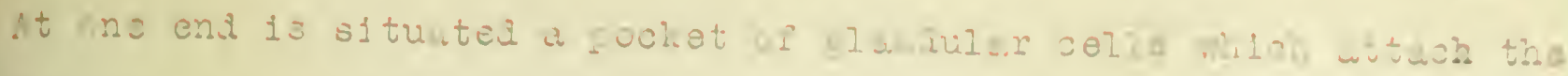
sporocyst to the host. Thi= is kona by the exustion of a wacus. At the antinodel end is the germinal epitheliur, from whin yeru bails arise. Only a fer cercariae lavelop within ths groruoyst it any une time.

the blacter uf the excretory system is uruncate, witi a cchinun median vessel Iea.ing into it from tha anteriur end. Iining the vesicle at the anterior end ure six glans eelis puirew right wrow left. They wpear as small tuberovics suspendek fruth the anteriur wall of the vesicle. Anterior to the melian vessel ure two coriua, Elonaate, yet swollen, reaching anterc-later hi around the ac itaisulum lear the acetasulur there are recivel the common posterior and the tro anterior tubules. The cattem of the capillaries is racomose. The tail truik syster consists of a comor reslich vessel with many

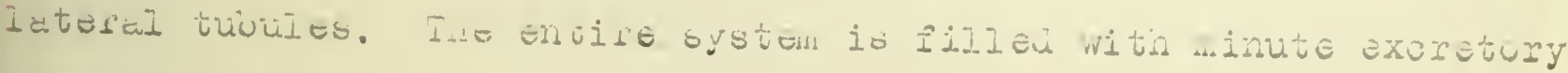
granules.

The digestive system consists of a very long esounagus, near the anterior end of which is tha small sphincter, ani from the posterior end of wich the furcae arise. They exten arjund the ucetabulun, The salivary-mucin glands consist cf rijht and lert wires. groups of cells, eight to the group, with long lects leaing in a common bunile to the oral pocket.

In the region of the cerebral ganglion a pair of oval boaies, the non-pigmentel eye-spots are located. They are a case of degenerate eyes similar to those descrite for cercuria eracilima $(0.91)$.

The genital cell masses are found in the region of the acetabulum (Figs. 104, 107). To the left is Laurer's canal, and running dex- 

tro-laterad is tire closely coiled uterus. The gonitui gore is of the right of the ria-ventral line, anteriur tu t.o wetumiur. Funning into the ootype from the postern-lateral ureies are tie viteiIine aucts, comecting the vitellaria vith the uotme. The tested sre not well dieine... The exact relationship of the cercaria is Lot evilent frum the genitil cell masses.

uystogencus cell glands ars present, altho lut is consicucus

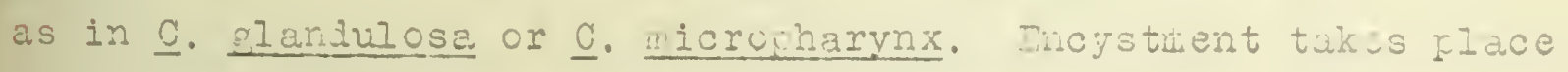
after a considerable period of free-swiring life. Decaudaticn almays preceles encystrent. The cyst wall is thin; the unimal is sasily viewed thru the cyst. 



\section{Fonirostone Cercaride}

\section{Cercar1a trisolenata Faust 1917}

Cercaria trisolsnata resesents a miuue ty:e uf cc..irusture -arva (Fis. 109). It is rore attenuate thun the wrerage s,eciee of tilis family, anj, amone the larvae of the funily, fus wn unusull iy short tail. The boly has an average length of 0.15 in... ard a widin wt the preacetabular region of 0.1 m. The tuil is about $\mathrm{u}^{3} 3$ nm. long, lanceolate, and nsisures $0.03 \mathrm{~km}$. at the base. Ar unterior region of the trunk, neasuring $0.03 \mathrm{~mm}$. al ong the malian line,

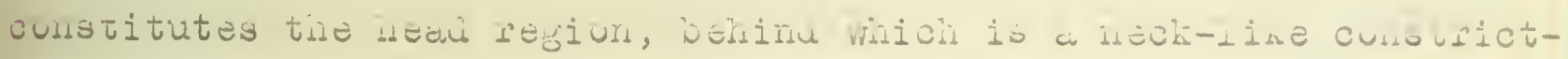
ion. There is a collar of 36 spines along the marein of the head, urrarged in a singlo irregular series (Figs. 110,111). I..ese spines are bluntiy roundel at tre base and tanen to a roundes point at the Iistal end. They are from lin to lum in length. The boty as a whole is usualy coveres with minute spines. The acetabulum is beset with an irregular arrangement of crooke. spines (Fig. IIa). The oral sucker is small but poweriul, 332 in aicreter. The acet $30-$ ulum, situatej behind the nid-plane of tine body, nevsures 4 wu.

"hese cercariae, together with cercaria gracilima, wre the most cosrocolitan species of the Bitter Foot Rivar. They occur in Physa evrina from the upper and lower reaches of the Valiey, and in Planowis trivolvis from the resion of the Duckhouse Bridge. The infection of the host os always heavy, buth es relates to numbers of individuals infected and the number of garasites in the individual host. The per cent of infezticn ranges from $2 z$ to 100. Ihe parasite is locaten primanzy in the interstices of the Iiver, but frequently irvades the cocal walls and dows ereat iniury to tha tissres. 



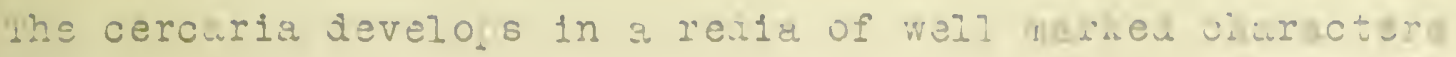

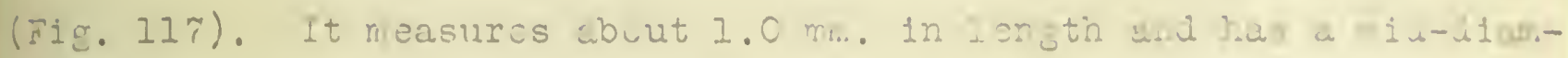
eter of $0.32 \mathrm{ma}$. and a gross wiuth uf $0.35 \mathrm{~mm}$. across the rejich of ihe loconotor feet. A small oowerful pharyax ut the cretericr end crens into the ribdocoel gut which ilils he greutar purt of the boay cavity, extanding alnost to the foste-10r extrarity. Here at the posterior eni is the germinal epitielium. Fron inis layer develop the Furtherobenetic ova, wich wic into cercuriwa. ne first charweter of the gem bali to beccme lifier sunerficially is the oral sucker (ee series lo stteas in fijure 114). Iater the tail and the wetabulum becone marke. off, anz firaliy the oral hood.

line cechalic en of the exoretcry system is must striking, and has, un to this time, no countervart anong alsorijes echinostome

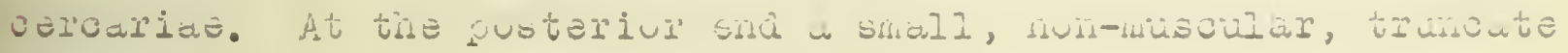
oladuer is situated. It oyens anteriad irto two single mancinch ad tubss. Tiase can be tracen cecialad irside the inusstinel ceca to the heal of the worm. here, lateral to the gharyx, a triangular chanral-system is found. From the snterior an le a smell cupilany leais oack to a single Ilame cil. From each of the other two angles a small capillary laas back to a Iluri celj. Ihis cuistitutes the trisolenate system at the antericr terminus of the exoretory tract. The tail exoretory tuies is a singla melian structure and has no linterals cr teminal outlet. wis fact necssiuates a revisicn cf the schene rucposel by Cort (1915: 37), in wiat this witer cheracterizes the excretury system of eoninostore carcuria

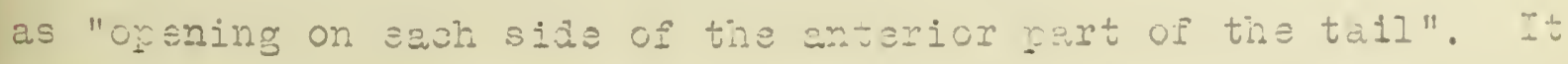
seams Irom the present investigation thut the thros flue oeils 

in the anterior firt of the trunk my be a ore rosulible ariterich for distinguishing the exeretoiy systek of this group. Furthon rork on other forms wist be ione before this acn be icfirttcly proroses.

Exoretory granules fili the latercl excretiry truks frow the phurynx racion ws far osuzaz is the acetabuluh.

We dicsstive system is simple. It consists of a long csopluys, with a very small fharymx scinoter ciocut in its midile, un two very Iong furcas, extenking to the sub-cauial rejion.

'he genitel call mases are yet very imature. Irere are four ceil masses rresent, ure on the upoer wight of the weetiouium (Fig. 130), the vagira; che osini the weetabulum (Fid. I31), the cvary; ani two taniem msses in ficnt of the blulier (Fig. Iio), the tastes. In the vicinity of the overy are rumercus viteliine flilicles, but they have ret been fund to folluw wy deinite pattern.

the nervous system. of this secies hes ben wane the ousis of tho jiscussion un page, and nejas ac further ponsileratiun here.

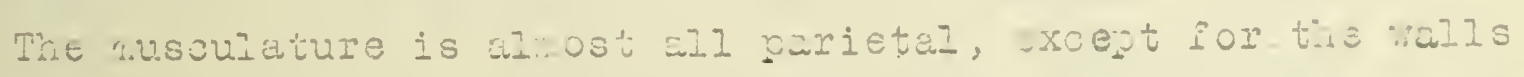

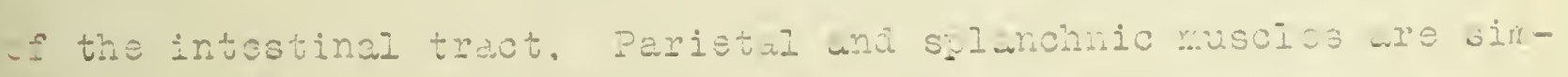

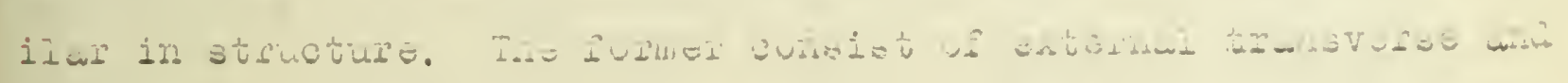

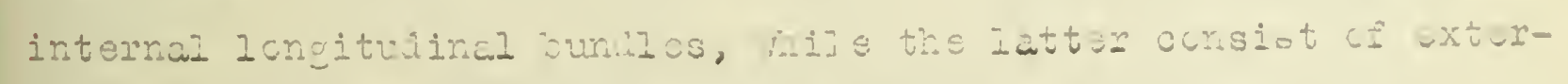

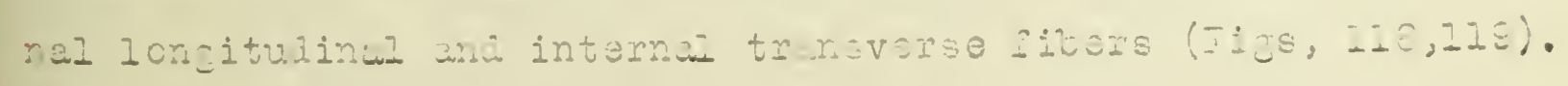

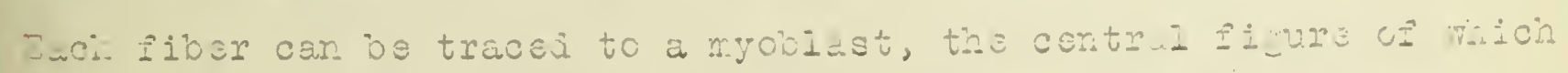
is the lurge ovel rucleus, with karycsone ani rabiuting zrcossses, so thit tho incle zijurs arears steliate. There ura severti fibers originating from each wyoblest; they wlwis run alcng a sincle axis. The Iorgitunind wuselas of the twiz wro proninent. (Fig. 133). 



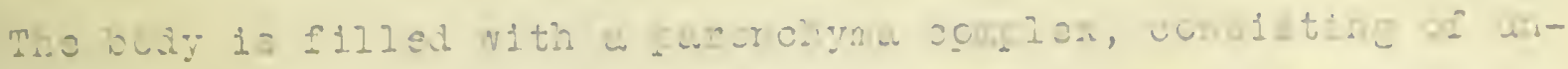

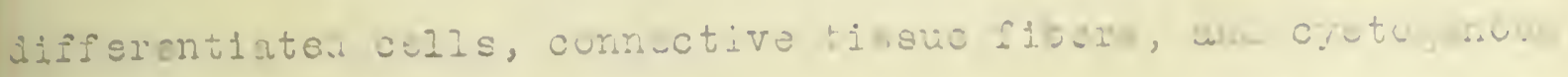

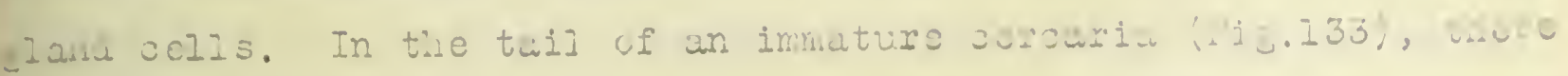

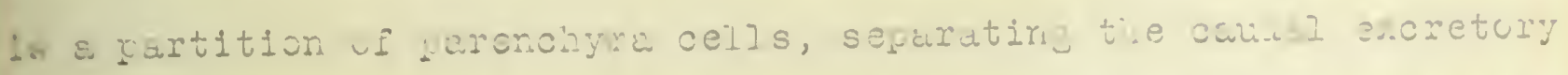

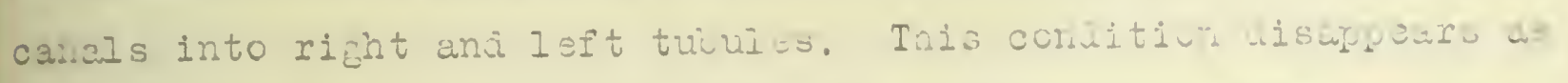
the aningl matures, aitho vestires fi these alis kny ie funh in tha matire cercaria.

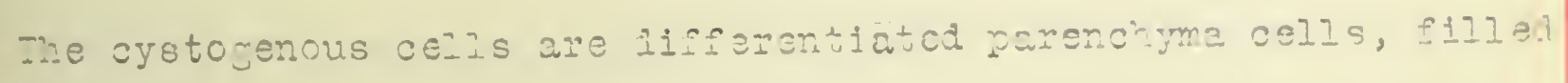
with a mucoid in the fom of oval granulis. In tine orlinary cyst- gensus cell (Fiñ. 113), the granules are aivout iu by 0.34 in

section. Trere is a cortrel nuoleus to cach of these cells, with poorly defined membrane secarating it ircn the eytcplesm. It is cont sxicucus becanse of its 1 arga whiber of chromatic granulos, corposed of elongate flecks. These flccks wre also rresert in corsiüerable numbers thruout the cytoplesm; they are especielly massed egainst the cell-walis. The glunis are best beveicyed in the rildie ci the body (Fis. 108, sections bb and da). As right be exectea ir a s:ec ies with such well leveloped oystogenous glanis, the cyst waIl is ieavy (Fig.115,A-C). In orevilng over the surface cf any obiect the mature cercaris. squeezes off the tail by a constriction of tice ccsterior transverse muscles. A final ierk of the tail frees it from the body. Immediately the oystogencus glands pour out a micus around the contracting worm, so thet at jirst ar cval cyst is forwed. Later, as it hariers, it assumes a more syhericel outine

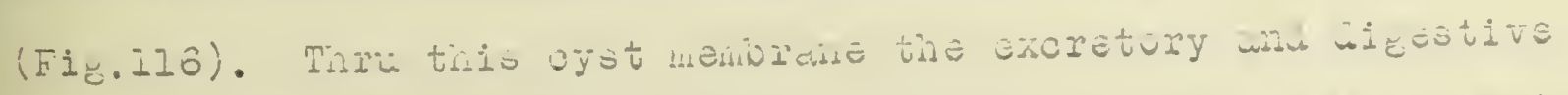

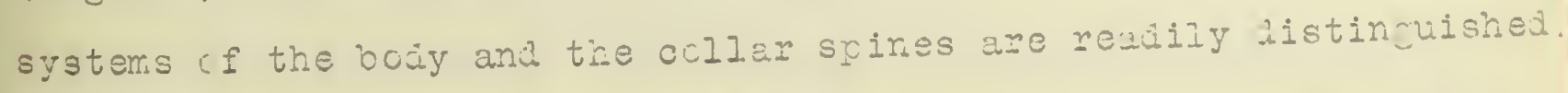
The cysts are so weIl walieu ani so nuierous that they suraest a considerable period of wintering over. 



\section{Cercar1a b1flexe Faust 1517}

Cercaria biflexa belongs to the type of chinostone cercuriue iistincuished by a smocti bodily outline, a lone owerful tall, biut orkl hocd srines and a reflexed excretory tule. The excretory system workes out by Looss (1894:fie. ISI c) for Distomum echinatum aproaches the system in this species, but siffers ircm it in many details.

The body of cercaria Diflexa is elongate ovola, with w sight ccrstriction just behind the oral hood(Fiqs. 134.135$)$. Beth the boly and the tail are extraorinariiy muscular. The body measures $0.45 \mathrm{~mm}$. to $0.5 \mathrm{~mm}$, in length and $0.15 \mathrm{~mm}$, to $0.15 \mathrm{~nm}$. in wisth. the tail is at least as lorg as the boay or slightly lorger. Its width is abcut $0.05 \mathrm{mr}$, at the base. The orel sucker has a diam-

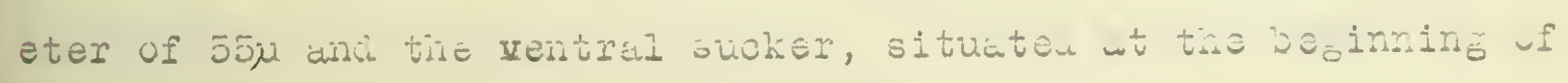
the posterior thira of the bojy, measures $35 \mu$ in wianeter. Around the oral hocd is a circlet of coliar spines, fa in number, cvoid elongate, bluntly rounded at both ends, with a length of loy to $15 \mu$ and a trickness of $3 \mu$.

The parthenita is a redia with a length mezsurement of 0.4 mi. and a thickness of $0.088 \mathrm{~mm}$. (Fig.137). The locomotcr feet are short, blunt processes in the posterior third of the boay, and have a gross scan of $0.1 \mathrm{~min}$. In contrast to the laree eut-rouch of cercaria trisolenata Fartienitae, the reilae of this speoiss have short inconscicucus rhabdoccel guts, only $0.1 \mathrm{~mm}$. in Iongth. Onethird of this is occupied by the pharyrx. The boiy wall is ccvered with a thiok integument, within wich is a heavy muscular layer. At the rosterior ens are a number of amall scinous projections (Fig. 141). At this costerior end is the cerrinal epithelium. 

A noticeable feature of the oleaving ova is their fluttersi conaltion (Fig. 141). Ttages in maturation and cleavaje ure seen in this firure an: may be conpared with similar stagcs of mptruation and Aevelocment in $\mathrm{C}$. trisolenata $(\boldsymbol{P} i \mathrm{~g} .1 \pm 0)$. The cercariae, when Lature, escape trru the birth-pore situate- ventro-sateral.

A promonent excretory system is fund ir this cercaria ( 1 iz. 155 ). The vesicle is a cylindrical organ inflated posturiorly. It is not muscular to any marke. iegree. Tukular cornus emity into the anterior end of the bladier. As these cornua are traceu forward lateral tributaries are found to mpty into them at regular intervals. In the region of the pharymx the tios become attenustel and flex twice upon themselves (Fig.138). The detailed Jescrintion of this arterior end of the system of Cercaria oilexa is foun in the section on morcinclogy $(c .63)$. It mey oe nctei here that there are trree flame cells along tre course of the ultinate tioule cf the system, and that these seem comparable to the three flame cells fcund in this system in $\underline{c}$. trisolenata. The excretory tuoe in the tail is a single melian tioe for abcut two-fiftis cf tre way distad, at wich point it forks and continues doule the remainier

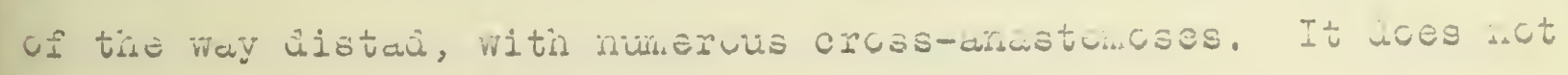
oxen to the cuisiale either on the siäes or eni.

The digestive system consists of an extremely long esophaglis, extenaing all the way to the acetaculum; funcas winich ena at the caulad end of the animal; and salivary-mucin glands, develoned to a very high depree. These latter consist of an irner and an outer series of right and left groups (Fig.134). Were are from ility to sixty cells in each grcur, in oblong clusters, with i comon -iot arterior to each series leajling oapialad. The trio ducts of each 

sike fuse to form a sincle lateral duct which leais into the cral pocket. These glanis are iifferent, then, from the rijority of muin glanis ir being aifferentiated into inner and ouver series. she coniticr is similar in rart to that in Cerosuia crenuta (Fia. 55), in wich species there is also a louble series of glunds cn each side of the esophagus. Sut in this cuse the glands of the inner and outer series are not jifferent in structure or seeming furction as in $\underline{\mathrm{C}}$. orenata. Herc, too, the liucts are not composi of

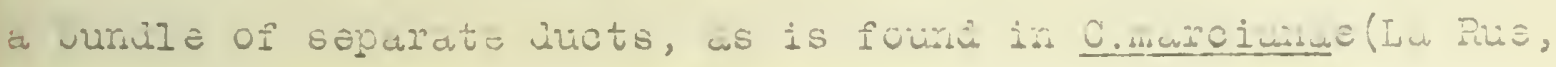

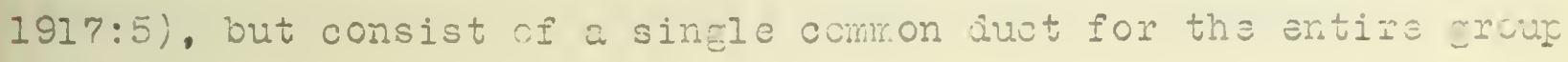
of $€$ land cells.

The genital system is much further edvanced in this species then in ․ trisclenata(Fig.139). Behind the acetabulum is the cvary, from which a literus leads around the acetaiculun, ening in the creacetablar region in a swcllen verina. Only the transverse ducts of tre viteline system are differeitited. Dehind these are the trio testes, linequic in size, cra abcve the other.

Tha enoystment of Cercaria bifleza is similar to that if $\underline{C}$. trisolerata. It lecends on the secretion of mucuids frcm a large nwiber of cystcenulis glands in the parenonym. The physiologic I ifferentiation petween ercystment in the two species is fcund in the Aifferert time and clace of encystment. The rature Corciris irisolerata eroysts orjy after it hos escepei from the liver tisslies of the host. The mature $\underline{\underline{c}}$. Diflexa encysts mithin the host, imreliately uron brsaking trru the birth-yore af the redia, Thus a section of Plunorbis trivclvis Iiver tissue shows tre interstices of the liver ceca filled mith excysted cercariae, wich continue to grow and differentiats within the primary host (Fic.15s). 



\section{Cercquis macilina Thust IEI?}

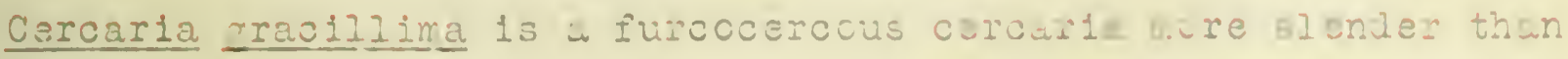
those previously described. Inis species, tcether with $\underline{\text {. tuber- }}$ istoma $(0.146)$, constitute tho seccnd furcocercous cercuriae to be described for lorth America, the first being $\underline{C}$. douthitt Cort (1915:50-52; figs. 55-34). In addition to the forkel-ta1l character of these three species, they possess in com on no pharynx, and have paired salivary-mucin glands lealing into the cral pocket, composed of four cells to each group. The "eyelet" excretory anastorosis, connecting the excretory system of the body and the tail, is also a common character.

Cercarla gracillima has an oblong cylindrical boly (Fig.142). The branched portion of the tail is elongate lanceolate. The body length varies from $0.13 \mathrm{~mm}$. to $0.16 \mathrm{~mm}$, and the diameter of the wom

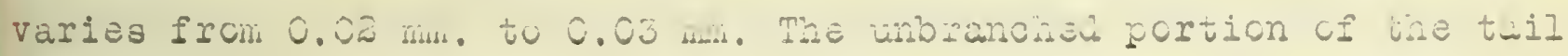
is about $0.16 \mathrm{~mm}$. Iong and the caudal rami are of equal length. The former is $0.02 \mathrm{~mm}$. to $0.03 \mathrm{~min}$. in aimeter and the latter has a width of $0.01 \mathrm{~mm}$. The trunk is characterized furtier by the absence of a true oral disc, ani in its place has an invertuble sucker. A ventral sucter, $12 \mu$ in diameter, varies in location, accoritng to the movements of the animal, from the middie of the ventril side tc a coticn considerably farther forward. The oephalio region is ovately rounded when the susker is fully distenied and is cromed by a cap of small scines. A feature op this cecolizia, in coniton with thet of $\underline{\mathrm{C}}$. louthitti, is the possession of eye-spots (Figs. I44. 150). But the eye-spots of $\underline{\mathrm{C}}$. rracillime are the thore vestigial, for trey have no piment.

This species was founi in the livers of pysa ywina Esy, col- 

lected from the lower reaches of the Eltter Rcot Fiver num ltwolloy Bridge, Juckiouse silare, and the sloughs at the Fidalouse. In

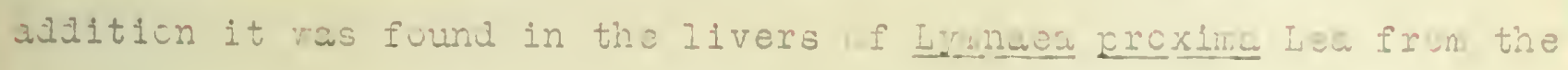
nattlesnake creez, "rissoula. The infeotion in wost cases was not exceclingly heavy, but in the collection fron the sloughs at the Foalhouse, thirty-thres cut of seventy-cha indiriluale were infected, or 43.5 per cent.

The cercariae develop in long cylinarical scopocyste, veryin: in length from $0.35 \mathrm{~mm}$. to $6.1 \mathrm{~mm}$, but most frequantly averaging evout $0.5 \mathrm{~mm}$. (Figs. 146,147 ). In iiameter the gporooysts viry from $0.3 \mathrm{~m}$, to $0.1 \mathrm{~m}$. The partienita is a simele strupture, nonmuscuiar, depending on the hiughter cercartâ for tia novement. At one end (Fiz. I4r) is a non-muscular attachnent area; at the other end, nerely a rounded non-ifferentiatec cup. The geminal epitheliurn is I0celizal at the attachrent end. From this nass the daughter worms develop. Internal pressure from the developing lurvae increases the length and ilwheter of the of the furthenita. In development (Fig. 143), tra ovoid gern bali first aiferentiutes a tail rortion; later the rami appar. It is not tili considerably later that the acetabulur is found. The oral spines aprear only visen the Iarva is wauture.

The movenent of the cercaria is characteristio for the furcocercariae. The mair novement consists in a very strenuous beating and lashing of the rami, so that the head is pushed into the object with wioh it comes in contact. In case the heul is not foroed into the ojject, the worm is set free by a bakwerd novenent of the tail and the entire worm scuirms around until it comes in ocntact with ancther object, when the same borirg movenent is arain 

attempted. The crul ena of the cercariu is much better ala tou to this type of invusion of the tissues to be iniected ther if it tossessed an oral ilso.

The excretory syste.. of C. axcoillima is embryologiculiy is sinle pulied system for both boly ani tall. As developrent and if ferentiation of rarts progress the tubes in the posterior extremity of the trunk and the anterior region of the tail fuse, to form a melian bladier and the comion tube of the proximul region cf the tail. There remains tho blfurcate portion in tho laterals of the trunk and the rami of the tail, and in aldition, the "eyelet anustomcsis". Tais ejelet structure has been cboerves by Locss for Cercaria vivax sons. (1896:17z-174; 1.15$)$, ani by cort for C. douthitti (1915: fig. 5\%).

The excretory system in tho boly consists of two lateral tubes that diverge from the bladier and can be traced forward, together with denaritic tubules and capillaries, the internal ones cf which srequently form chiasmio anastomoses across the reaian plane of the body. Slightly posterior to the midale of the boliy the lateral tube expands and cpens into a pocket provided with cilia (Fig.145). These cilia comefrom a flame cell bordering ch the Iumen of the lateral tube. A second pocket somethat anterior is an atrium into which many of the capillaries emety; it is filled with small excretory granules, in this way acting as a secondary reservolr.

the jigestive system of $\underline{0}$. gracilima consists of an unoranched esophagus without a charynx sphincter, a vair of short furcas extending anterial around the acetabulum, and a ring of gland cells in the region of the esorhagus where the pharyn might be expected. opening into the oral atrium thru comon bund s of lucts are the 

salivary-muein glands (Fig. 144). These ganis are vary taile nith vesicular nuclei. They are situated in tis postericr tiniri cf tise boly. In cross section the sucts ara similar to thosc issoriud

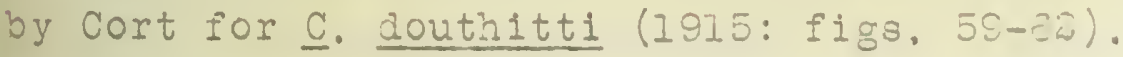

The nervous syster has been discussed on $x .91$.

The genital cell masses in the cercarla are Keriaphrolitic. Fig. 149). Anterior to the acetabuium are the vajina aliw the cinrus ouch buis, and loteral, extending both anteriad and posteriau, are tho viteline follicles. In the posterior extrenity is a conicil Eerminal mass, from which are jroliferated anteriud a nunber of small testicular follicles. 

Cercaria tuberistcma Faust 1917

Ihis species of cercaria is shorter and wuct more uscular then ․ gracillima. The boly is elongate ovold, with the anterior end sidghty constrizted and crowned with a pair of tubernsities. (Fig. 155). "he bodily length is aoout $0 . w$ m.. and the wiath 0.05 $\mathrm{mm}$. to $0.05 \mathrm{~mm}$. The tail miasures about 0.32 mim. as a wicla, equally divided into common portion and rami. Inere is no or I suctorial disc, but instead the oral invertible sucker. The dcetabulum neasures $0.03 \mathrm{~mm}$, in jiameter.

The cercaria was secura from a single light infection of physa rypina collected in the Bitter Root River at Corvallis "untana in Octover 19lo. Dut of nineteen snails exmined only cne was infictej Unly a few cercuriae were securen, and these were stuiled as jive mounts. From this study the sxcretory, digestive and generial boaily fatures were worked cut.

The cercaria develops in a sporoyjst, elongate, Jumb-bali sherea, cr spreajing out at one end tu form an uttachment lise fijus.I57, 158). At the ens oprosite the attachment urgan the cercariae arise from the maturation of the exringl exithelium. They escape thru a rent in the wall of tha scorooyst. Stages in jevelopment

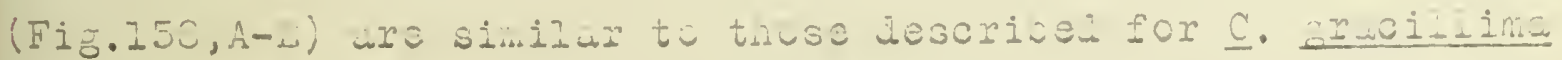
(Fig.143). On the whole the moryos of this sreoies are stouter. ihs excretory syster has the features comon to all furcocarcarias. The bladier and the eyelet are musular (Fig.155). The zateral tubes are of small diameter, with anterior and rcsterior tubules. iro anastoroses take place in the cercariae of this species. The median tail tube receives six lateral trioutaries, the untericrmost of wioh is reflexed. The rami have each an unbranchen turule. 

The cephalic region is muked by in lugge invertitze ouckar, oxtending thru the anterior thiri f tha uly. The infeotinis zecu extend arcund the acetabuium. Io glands surround tis esoghagis as a listinct ring, altho the entire esophazal tube lirire is gianular in nature. Fout small salivar:-rucin glands wre situwtod in the postesior third uf the boù (Ijig.Ib5). Their lucts emty severately into tho oral cavity. The cails of this systan wing filleà with closely aroregated, dealy stainire granules. Tho nuoleus of the sulivary-ruoin gland çll is extremely small.

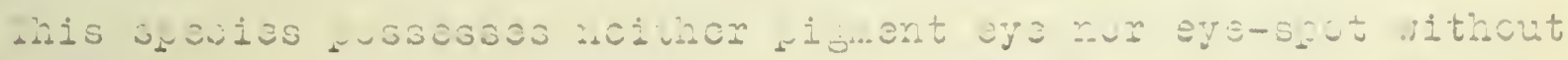
riement.

Lnoystwent has not boen obsurved in this snecies. 



\section{Pathology}

In any case of internal parasitism the infection suggests an inquiry as to the effects of the parasite on the host. The injury on the human subject produced by trematode infections has been the subject of numerous observations and records. Notable among these are the contributions of Looss(1913) on Schistosoma haematobiurn, Katsurada (1914) on Schistosoma jaovnioum, and Ward (1909) on Fasciolopsis spp. Again, the effect of tromatodes on their host has been the subject of considerable study in fish infection, on account of the economic importance of the problem. But where the special incentives to the problem have been lacking, very little study has been made on the pathological significance of trematode infection.

The helminth parasite causes a two-fold injury to the host, mechanical and chemical. The inclusion of parssites within the organs of the host is the occasion for distension of the organs and consequent irritation, the piercing by the amature of the worm an actual mechanical injury. These injuries are accomaniej by the formation of fibromata within the organs and usually attempts to isolate the parasite by the secretion of a cyst arouna it, as in schistosomiasis (Bovaira and Cecil; 1914: 191). In the ordinary infection a toxin is secreted by the parasite, and frequentiy an anti-thrombin and a hemolysin are proaucea. Such injuries as these in higher animals may be diagnose. by the blood-picture, where excessive hemocytolysis and eosinophilia are found.

The infected organs of the molluscan hosts of the Bitter Root Valley are the liver ceca. Altho these lis next to the testes, the worms have never been found to invade these organs. 

Thomas (1883; 114) foun.t that the cercariae of Fasciola nepat10a live normally in the pulmonary chamber of the snall Lymnaea trunculata. Cort (1915) found the infectex organs of the Campolems. were the gills, but in other species, the liver tissues were the seat of the infection.

I'he liver ceca consist of poly ronal lymohocytoidal cells grouped around the lumina of the ceca, with an epithelial lining surrounding the ceca. Among the ceca are large interstices filled with lymoh. These inter-cecal spaces are the places where the worms are first found, suggesting invasion tiru the blood stream. In light infections, the parthenitae lie rere, absorbing the nourishment from the surrounding liquid in wich the worm is bathed. The only mechanical injury up to the time of the activity of the cercariae is caused by the agitation of the developing larvae encysted within the host. But in the case on heavy infection, especially where the larva does not encyst within the host, where It works its way out into the water, even a few worms may cause considerable mechanical harm to the host.

In an examination of living material and sections of infected mollusc liver tissue, no infsction was found to be so light that the hoot was uniharmea. In the Cercaria biflexa infection of physa gyrina (fig. 159), where the cyst membrane is moderately heavy, many ceca are uninjurea., yet some betray the marks of injury. One such injury is show in the figure. In this case the cells of the ceca have undergone only a littie change. A comparison of this condition with that of $\underline{c}$. micropharynx infection in Lymaea Eroxima (fig. 160) and $\underline{\mathrm{C}}$. gracillima infection in Physa gyrina (fig. 161), shows a comparatively small injury in the former tis- 

sue and a severe injury in the latter tissues. I3oth the latter cases show degeneration of tissue. The chemical change in Lymnaea proxima is evinced by 1) fatty boiles that have accumulated in some of the cells (a), showing as highly refractive inter-cellular inclusions; 2) large vacuoles in the cells (b) , especlally around the nuclei; 3) cytolysis and karyolysis (c, d), including a sloughing of the tissues in the region of the lurnina of the ceca. The condition of $\underline{c}$. gracillima infection in Physa gyrina (fig.161) pictures a further degeneration of the tissues. Fatty globules are common, usually accumulated as spherules within the wall. VacLolization (a) has progressed to an advanced stage. Cytolysis and karyolysis (aㅡ, $\underline{\text { ) }}$ have gone so far that the outlines of the majority of the cells are indistinct and no difference exists longer between the epithelial and the lymphocytiodal cells. An indefinite, irregular margin marks off the ceca from the interstices in which the cercariae lie. A further change consists in the formation of Ilbromatas (e) and granulomas within the degenerating ceca. Finally the epithelium surrounaing the entire liver mass has been penetrated by sand granules (f), and other foreign booles have access to the tissues.

In the infection of Planorbis trivolvis with $\underline{\text { C. trisolenata }}$ the mass of the worms was about twice that of the liver tissue infected. The tissue was so distended with the parasites that a prick of the needle was sufficient to cause the liver membrane to burst, upon which the rediae and cercariae fairly poured out of the tissue.

l'he data on the effect of the agamic trematode infection on the molluscan host are significant. No infection is so light that 

mechanical and chemical injuries are not inflicted. In the heavy Infections such as are common to the malluscs of the Bltter Root Valley, the 1njury is so heavy that it must alter appreciably the Iife of the host. The mechanical pressure tends to inhibit or increase the functioning of the glanaular organs and cramps the tissues within unusual confines. The presence of foreign proteins in close association with the lymph sinuses is sufficient to alter the vital economy of the host. The boring of the wom destroys the t1ssues locally and in general irritates the mechanism, exposing It to bacterial infection. The secretion of digestive juices by the parasite, and of anti-tnrombins and possibiy specific poisons, upsets the entire physiological equilibrium of the organism. 



\section{Problems Presented}

In working out new species of organisms, especially from new geographical areas, there are often physiological and morphological facts that are of general significance in the light of previous studies. It is the relationship which is the ultimate problem in all work in morphology. While light is shed on phylogeny by the discovery of new species it is futile to expect to found a system of phylogeny on a single species. With these limitations in mind the writer presents some of the more important questions that arise from the study of the agamic trematodes of the Bitter Root Valley. Certain recent investigators have come to regard the trematodes as a polyphyletic group. Their conclusions have resulted, perhaps, from their inability to recognize the fundamental resemblance of the nervous systems of the subiivisions of the group, especially during the embryonic period. In the early days cercariae and rediae were considered as different groups of the animal kingdom, and it was not till the Iife-history stuiles of Leuckart, La Valette (1855), and Ercolani (1881, 1882), that the genet1c relationships of cercariae and parthenitae were established. It is generally recognized now that the germ layers of all generations of trematodes have a similar origin, and that the important structures of the group present the same problem.

From more convincing observations odhner (1907) has concluded that the Monostomata are polyphyletic. This investigator has noted among certain monostomes a structure comparable to the pharyngeal pockets of amphistomes, and among others a primitive acetabulum (1911). In a study of the monostome cercariae frorn the Bitter Root Valley, the similarity of the nervous system and genital 

cell masses of Cercarla pellucida and those systems in Gastrothylax gregarius Looss has been noticed.

Both Cercaria poliuciaa and Gastrothylax gregarius show paired brain ganglia closely set together with only glight constriction of the dorsal commissure. In both species the nerve cells 119 superficially upon the central nerve ganglion masses (Looss, 1856: fig. 6; fig. 23, this paper). Noreover, relatively large posterior ventral and smaller lateral and dorsal trunks, together with their relative positions, constitute a series of similarities not to be overlooked. Looss has found that there is an intermedius nerve in his species, both anterior and posterior to the brain center. No meaian posterior trunk has been observed in the cercariae of this group, and the relation of the median anterior trunk to the dorsal pigment eye has caused the writer to regard this nerve as a fused anterior dorsalis. The lack of pharyngealis, palatinus, and dorsolateral comissure (figs. 123,124) serves to show that the nerve complex of the monostome larva Cercaria pellucica is not typically distomate. Its structures are much more readily referred to the Gastrothylax type.

In the second place certain features of the genitalia of Cercaria pellucida and Gastrothylax suggest a comon ancestry. The median cvary in the subcaudal region (Looss;1896: figs.1,2;18, this paper; the paired testes lateral to the ovary; the dendritic vitellaria located in two series; and, finally, the parallel course of the uterus and the vas deferens to the genital pore far cephalad, - all of these show in common a genital system quite distinct from the usual distome types.

The similarizy of the nervous and genital complexes of the larval monostome, Cercaria pellucida, and the amphistome, Gastro- 

thylax grepar1us, suggest the common origin of certain monostones and amphistomes.

Among adult distomes there is great variety of structure, yet only in one family, the Schistosomiare, has the fundanental nervous system been altered. The structures of the two furcocercous larvae, Cercarla gracililma and $\underline{\mathrm{C}}$. tuberistoma, have suggested their fundaniental resemblance to the Schistosomidae. For this reascn we shall consider briefly the reasors on which this hypothesis is based.

l'he characters which distinguish the apharyngeal cercariae of the furcocercous group are as follows: 1) a forked tail (Iarval character only); 2) paired groups of four salivary-mucin glands (Iarval); 3) absence of an oral suctorial disc, and in its place 4) an invertible suctorial pouch; 5) an apharyngeal esophagus, provided with glands in the regicn usually occupied by the pharynx. Nore deeply seated, the nervous system consists of a structure distinctly different from the usual aistome tyoe. This modification consists of the degeneration of the posterior laterales during early embryonic development, and the fusion of the posterior dorsales with the posterior ventrales about one-third the body distance back from the anterior end (fig. 150). All of these characters, except the forked tail and the salivary-mucin glands hold over to the adult trematode. In adition to these characters, the larva of Cercaria gracillima has several testicular follicles proliferated from the posterior testes-mass at the posterior end of the body.

Certain of the structures of this group also characterize the larvas of other groups of trematodes. For examole, cercaria cristata La VaI. (1855: 23; Taf.IIK), has a bifid tail and apparent- 

Iy lacks a pharynx, but the fact that it lacks an acetabulum, probably separates it from the distome furoocercariae. Nrong the Gorgorderinae we finc apharyngeal cercariae with several testes. However, Ssinitzin (1905: 46-51; Taf.I,II) has show for four Gorgordera species, that the cercariae are characterized in common by 1) a stylet, 2) salivary glands only in the cephalic region of the body, 3) a large glandular excretory vesicle, alrost filling the posterior third of the boay, 4) two testes situated obliquely behind the ovarian cell mass some distance from the posterior margin of the body, and5) a disproportionately large tail, showing the cystocercous relation of the larvae of the group. Moreover, the nervous system is typlcally distomate (Zailer, 1914: 380).

It may be stated with considerable probability that all of the funciamental organs of the furcocercariae, namely the apharyngeal esophagus, the multiple testes, and the uniquely modified nervous system, are found in only one adult family, the Schistosomidae. All Schistoscmidae described are characterized by the absence of a true oral suctorial disc and by the presence of an oral invertible suctorial pouch. They have no pharynx, but in its stead glands that line the wall of the esophagus. Looss has described the modified nervous system of the family in his study of Schistosoma haematobium (1895:60-68; Taf.II,fig. 18). It corresponds in detail to the system of Cercaria graciliima.

Coupled with these morphological likenesses are the experimental data of Leiper on Schistosoma life-history work. Leiper has been able to show that the three schistosome soecies knom to infect man, Schistosoma haematobium, S. mansoni, ari. S. japonicum, give rise to miracidia which have a definite attraction for certain snails in the alstricts where he has carried on the investigations. 

Within the tisoues of these snalls the miracidia metumorhose into sporocysts, and the daughter sporocysts, arising from the mother sporocysts, give rise internally to bifid cercariae with a ventral sucker, but without a true pharynx. Furthermore, these cercariae introiuced thru the skin and mucosa of experimental animals, mice and monkeys, give rise to typical unisexual aiult schistosomes. This two-fold evidence favors the view that the distome cercariae of the furcocercous apharyngeal type, including Cercaria gracillima and $\underline{c}$. tuberistoma of the Bitter Root Valley, develop, under proper conditions, into auilt schistosomes. One character figured by Leiper for all his apharyngeal bific cercariae, yet not used by him as a diagnostic character, is the presence of the four salivary-mucin glands on the right and the simflar group on the left of the acetabulum of the larva. One character used by Leiper for the cercariae of the group, the absence of a pigment eye, holds for his three species of schistosome larvae, but does not hold for Cercaria ocellata La Val. ‥ Gouth1tti Cort, or ‥ gracillima Faust. On the other hand, it has been show that the eyespot may be present without pigment (e.g., in $\underline{\mathrm{C}}$ gracillima), hence the failure of Looss to mention an eye-spot for $\underline{C}$. Vivax Sons. (1896:216-223; pl. I72-174) does not imply the absence of a pigmentless eye-spot in that species.

The matter of the relationship of the bifio apharyngeal distome larvae will be made much clearer by a consiaeration of the male genitalia. The adult Schistosoma into which the larvae of Leiper develop are characterized by a relatively small number of testicular follicles, 4 to 5 for S. haematobium (Looss, 1885: 81), 6 to 8 for S. japonicum (Katsurada., 1914: 367), and 8 for S. Mansoni (Leiper, 1916: 411). On the other hand, the testicle pro- 

Ifferation in Cercaria gracillima (fig. 149) shows twenty-four or tmety-five follicles already aifferentiated from a posterior germ mass. The large number of testicular follicles has been show to be the characteristic of the adult Schistoscmidae of the genera Bilharziella (Kowal ewsk1,1895: 1896), Gigantobilharzia (Odiner, 1912), and Ornithobilharzia (Oahner,1912). On the other hand, the tuberosities at the anterior end of the Leiper cercariae are surely comparable to those of $\underline{\mathrm{C}}$. tuberistoma Faust. Unfortunately the writer was unable to preserve material, so that the structure of the genitalia of this species is not known.

The mass of evidence suggests the separation of the apharyngeal istomate furcocercariae into two sub-groups, 1) those with eye-spots, either with figment or without, and possessing a large number of testicular follicles; and 2 ) those without eye-spots of any kind, and possessing only a few testes. The fomer probably have an avian definitive host; the latter, probably a mamalian definitive host. According to this hypothesis we would

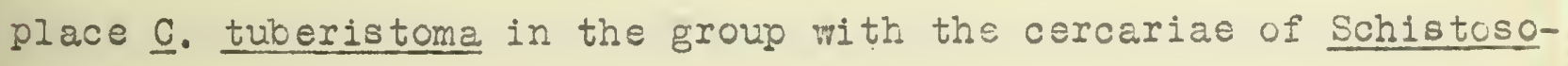

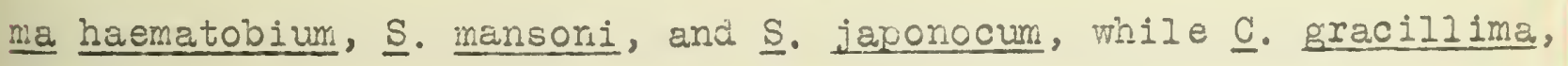
C. douthitti Cort, and possibly C. vivax sons. suggest a natural sub-group related to the avian schistoscme aülts.

A question of phylogenetic importance is solved when we come to know that the germinal masses of Cercaria gracillima are hermaphroditic, and that any marked differentiation of the organs does not take place while the larva is outside the definitive host, for with the probable genetic relation of this species of larva to the adult schistosome, we may expect the differentiation of sex to take place ir these species comparatively late in their development. This hypothesis is in keeping with the studies 

of Odhner (1912), who points out the funiamental rorphological relationship of the hermaphroultic species Liolope and Haptotrena and the unisexual Bilharziella, Gigantobilharzia, Ornithobllharzia and Schistoscma.

$\Lambda$ comparison of the table on p.28Awith the data from Oaner's paper (1912), support the view that the species of Schistosomiate with a small nuniber of testes ( 4 to 8) have as a definitive host a mammal, wile the species with a large number of testicular follicles has a bird as definitive host.

The discussion leads to the conclusion that the larvae of the two mein groups outlined above may be separated on the basis of 1) the number of testicular follicles present in the mature cercariae, 2) the presence or absence of an eye-spot (with pigment or without), ana the relative slenaerness or thiskness of the larva. At the same time they possess in comon l) a bifiz tail, 2) a ventral sucker, 3) an oral suctorial pouch which can be in verted, 4) a glanüular esophagus without pharynx sphincter, 5) pairea groups of salivary-mucin glands, four celis to each group, 6) multiple testes, anc 7) a specifically modified distomate nervous system. In the light of present knowlejge these species all fall within the limits of the Schistosomidae.

Of all the knom groups of trematodes the Holostomata have been the group of least genetic study and most erronecus interpretation. On account of their large size the adult holostomes have been knom for many years anô dozens of species have been described. Nothing, however, has been knom of the development of the holostomes. Without sufficient grounas Lrandes (1891;573) has interoretea the sketoh of a miracidium of Holostomum cornu- 

coplae Molin (v.Linstow. 1877: f1g. 30) as a metamor hosing tetracotyle. In other worls, Brandes concludes that the molostome has a direct monogenotic development without the intercalation of the agamic cycle. Ercolani (1881:284-290; Tay.II, figs. 13-2z) has worked out the Iife-history of Strigea erratica (Duj.) from the tetracotyle to the adult fom, by infecting Mnas sp. with Tetracotyle typica cysts from the mollusc, Planorbis corneus. Altho Ercolanl found one tetracotyle in a sporocyst (iav.II,fig. I8), he interpreted it as the invasion of the tetracotyle into the sporocyst of Cercaria ocellata La Val. Ssinitzin has iustly criticized Brandes conclusion (1910; 22,23), but in lieu of true holostome evidence in suport of the digenetic view he has substituted that from Cercaria plicata, a peculiar distome larva wich he has shom to bear certain relations to the holostomes.

It has been show in this paper that there are agamic cycles in Cercaria flabellifomis, a typical holostome, that several generations of rediae may be intercalated between the miracilium and the tetracotyle. Thus, there is conclusive evidence that the holostome has an alternation of generations, gametis and agamic, similar in kind to such alternation in other Digenea.

In spite of the strangely modified suctorial apparatus and the posterior genital organs of the holostornes, there seams to be good grounds for believing that they originałed from the aistomes, They have an acetabulum, and, at times, the rudinent of a genital pore just in front of the acetabulum (fig. 5z). On the other hand it is very doubtful if the lappets (Zapfenlappen of Brandes,189: Taf. 41, figs. 5-15) bear any horology to the genital pore rudiment. It has been show, in fact, that 

they arise in Corcaria flabelifformis from a pair of oval suctorial grooves (fig. 4I), and that in Tetracotyle p1pient1s (f13.47), where these grooves remain rudimentary, no lateral laprets develop. U. v. Linstow has renarked that the points of difference in Strigea (Holostomum) have been considered very superficlally, since the group members are not readily distinguished by cxternal markings asd the internal anatomy is difficult to interpret (1877: 189). Even in the early larva the points of differentiation are well marked. It has been pointed out $(p .22)$ that the parthenogenet1c egg of the holostome developing into the cercaria (tetracotyle) is structurally differentiated, even at the time of maturation, wile the egg which develops into a reala is morphologically simple. Such phenomema have been noted in no other agamic trematode study that has come to the witer's attention. Thus the actual phylogenetic history of the group is hidaen by its precocity, and the developmental stages of the holostome show only in telescopic fashion the actual ancestral history.

Extraordinary nerve modification in the holostomes (fig.53) is related directly to the modification of the muscle complex. This modification consists in the main in the degeneration of the posterior dorsales and laterales, and a relative increase in size and importance of the posterior ventrales. The other systems of the holostomes, especially the genital and excretory systems, are equally highly mosified and equally well formed in the larva. Ssinitzin (1910, 1911) has suggested that the changes in the genital pore from the preacetabular region to the posterior ventral extremity have come about thru the formation of a new opening rather than tiru a shifting of the old preacetabular pore. 

-15.-

This view is held by the writer, since the original genital pore is still present in the hemistome larvee, altho there is no clue to its former connection or function. The extent of these chunges indicates a long period of gradual adjustment to a moaifled m11ieu.

The study of the cercariae of the various groups of Digenea not only serves to supplement relationship studies of adult gametic trematodes, but also brings out structural relationsips very considerably if not entirely hidden in the adult. The most constant of all the systems in all the groups of Digenea is the nervous system. Any marked modofication of this syster from the characteristic aistomate nervous system is inaicative of a long period of divergent growth.

'he fundamental systems of the gametic trematode are deepseated: they are well formed in the cercaria, and little significant differentiation takes place during metaromphosis. Relation of trenatodes to other groups.

Among the early systematists Trematoda were classed with the Hirudinea because of the common superficial resemiolarce of the two groups. Even as late as 1871 Schmarda separated the Trematoda from the Turbellaria and Cestoda, and placed them together with the Hirudinea in the Cotylidea. Balfour (1881: 316,317) considered a direct relationsip of all Nesozoa above Coelenterata entirely unsatisfactory and conceived the fdea of referring them all back to the trochophore larva wich possessed radial symmetry. In his monograph on Amohistomum subclavatum Looss (189::156, 157) compared the proliferation of the germ-balls from the body wall of the parthenita to the production of eggs and sperm in the 

marine polychastes, and suggested that other embryonic structures of the trematode were comparable to to annelid structures, so that they might be considered as of phylogenetic value. Recently Ssin1tzin (1911:86) has spoken of the resemblance of the Trematoda to Arthropoda and Trochelminthes, in view of the absence of any ciliary integument, in place of which, he says, the cuticula and the external skeleton develop.

During all of this time there has grow up a theory of common descent for the Trematoda, Turbellaria and Cestoda, based not on the fact that thoy are all "flatworms", as Ssinitzin has insisted (1.c.86), but on their homologous genital, nervous and excretory systems. The observations of Leuckart (1886: 140), Schulze (1853: 178-195), and Schreider (1864:590-597) all support this view, while Leuckart (1.c. 141) even saw the analogy between the gutless sporocyst and the Acoela. Lang (1884: 669) showed that the nervous system of the Trematoda and the Turbeliar1a was homologous.

With the work of Haswell on Temnocephala (1888) the close affintites of the Trematoda and Turbellaria became evident. In this group the excretory system, the thres antero- and posteronerve trunks, the anterior mouth, and the dorsal pigment eyes,all these have bridged the way for the acceptance of the thesis that the Tremotoua and the Turbellaria have a comon ancestry. The study of the agamic generations of the Digenea, to wich this paper is devoted, stands in support of this thesis. The hypothesis is based on the following facts.

1. The gametic trematode is produced from a parthenogenetic egg, developed from the geminal epithellum of the body wall of the parthenita, or lying free in the body cavity. It passes thru 

a larval stage, the cercar1a. The sporocyst is frouluce from the fertilizel egg. Its larva is the miraciulum. The redia is the result of the development of the partienogenetic egg produced in the sporocyst.

¿. The body cavity of the gametic trematode and of the Turbellaria is filled with differentiated mesenchyme and connective tissue. In the parthenitae the parenchyma is confined to the body wall; it is also less differentiated.

3. Both Irematoda and Turbellaria aro typically flat, with a pronounced bilateral symmetry. The cynildrical appearance of the rediae and sporocysts is a secondary modification due ro parasitism.

4. The epidermis of the Trematoda and the Turoeliaria consists of a single layer of cells. In the sporocyst larva (the miracidium) and in the Turbellaria, the layer is ciliated. In the realae and in the cercariae this layer is usually sloughed off before maturity and in its place the tunica endogsna, of mesodermal origin, serves as the integument. This fact disposes without reservation of the Seinitzin theory of the Trochelminth and Arthropod origin of the integument.

5. The nervous system of the Monogenea, the Digenea and the Turbellarla is reducible to a comion type. Two brain gangla with a transverse commissure, three anterior pairs of nerve trunks, and three posterior pairs of nerve trunks, - these are comron to all three groups. Morsover, the pigment eys-spot of the Turoellaria, Monogenea, and Digenea (cercariae) are not only homologous, but practically identical in detail (Hesse:1897; and pp.90.91 this paper). In each caseoneor more ganglion cells fill the "optic cup". In each it can be traced to the brain center. Parasitism 

has caused the pigment eye to degenerate in the adult Digenea.

It is present in none of the mature gametic foms that have come under the writer's attention. Even in the cercariae it is pigmented only in certain species; in other species all traces of pigment have been lost, but the optic nerve is still present and can be traced to the brain center ( Cercarid gracillima, ‥ racemosa). In many cases it has been lost, even ir the cercariae. Eye-spots are comron in miracidia, but are lost on metamorphosis into the sporocyst. There are no records of eyee in rediae. 6. The digestive tract of the cercariae and gametic trematodes is usually triclad, altho in the Gasteropoda it is rhabdocoel. In the redia the gut is rhabdocoel; there is a pharynx and salivary glands have been reported (Ssinitzin, 1911; pp.76.77, this parer). In the sporocyst larva (the miraciaium) there is an indication of a gut and salivary glands (Locss, 189\%), al tho these are all lost in the adult. In the Turbellaria the gut is triclad, polyclad, rhabdocoel, or acoel. The pharynx is ordinarily present and salivary glands are frequently found.

7. The excretory system in the two groucs is at first a single pair of protonephridia. This condition is found in miracidia, rediae, and cercariae, and also in the Iurbellaria. The tubules, whether in larva or adult, end in flame cells.

8. The genitalia were one of the first systems in which investigators recognized the relationship between the Trematcda and the Turbellaria. The hermaphroditic condition in the gametic generation of the Trematoda and the Turbellaria is strikingly similar, with the cormon atrium, except in Acoela. Parthenogenesis in parthenitae is the result of the great change in environ- 

ment of these agamic cycles.

While one or two points have been advanced in support of the various phylogenetic connections of the Tremetoda to other grougs, only one theory has been proposed which is based on the fundamental homologies of the nervous and genital systems. Thisis the theory of common ancestry of the Trematoda and Turbellaria. The present study of agamic trematodes fully warrants the support of this theory.

The life cycles of the trematode.

The Iife-history of the trematcde of the Order Digenea consists not in an alternation of sexual and asexual generations, but rather in the intercalation of one or more parthenogenetic cycles between successive gametic generations.

It is the bisexual cycle to which reference is made by Lankester (1901; 89), when that writer remarks that "it is almost an axiom that parasitism leads to degeneration of the parasite, and this generally in an extreme degree; but in the Trematodes this degeneration is scarcely recognizable;for beyond the absence of the ancestral locomotor organs, viz, the cilia of the outer surface, it is scarcely possible to point to any sign of degeneration common to the group."

The majority of the Digenea are hermaphroditic. In spite of their complex organs for copulation Looss (1894a: 812) has concluded that they are usually self-fertilized. Among the Schistosomidae alone is there a separation into male and female individuals, and even in this group the genital cell masses are hermaphroditic in the larva (Cercaria gracillima).

A problem which has arisen in connection with the genitalia of the Digenea is the significance of the organ known as Laurer's 

canal. Looss (1893a) considers it homologous to the uterus of Cestoda, while Goto (1893) believes it to be the homolog of the blind vagina of Amphilina and the genito-intestinal canal of the Monogenea. Nccording to Lîne (1909) a Laurer's canal is present in Monostomes, and in some of the groups of the Distomes, inclucing Plagiorchidae and Echinostomidae. It is not recorded for Holostomes or Schistosomial. Except for the Echinostomiale cercariae a Laurer's canal has been found in all cercariae of the groups studied, in which the adult trematode has this canal. Absence of the canal in the larval Echinostomiase can be explained on the basis of the late development of the genital organs in this family. On the other hand, no Laurer's canal has been found in the groups where no canal is present in the adult. With the exception of Ssinitzin (1905: figs. 62,67,74) students of cercariae have not recorded the canal in trematode larvae. Ssinitzin has found it in the three xiphidiocercariae, cercaria gibba de Fil.

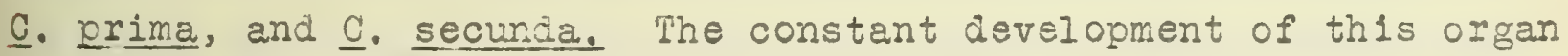
in several groups as described in this paper shows that the Laurer's canal originally had an important place in the sex physiology of the Digenea.

Whe pronounced difference in structure between parthenogenetic ova which develop into rediae and cercariae has been discussed (p. 22). This aifference has been found to bear no relation to the phenomenon of maturation, since the chromosome count in the mature cell is the some, whether redia or cercaria is to be produced. In fact, it oeems probable that the differentiation occurs before maturation. The significant fact is, the comparative simplicity of the ova which develop into rediae and the extreme complexity of the ova which develop into cercariae. In this 

connection it has boen observed that embryos developing from germballs produced from ova free in the body cavity prowuce daughter rediae. Of the maturing ova from the germinal epithelium lodged in the body wall of the parthenita, those developing farthest posterior invariably grow into cercariae.

In his experiments on planarians Child (1915) has shom that starvation and fragmentation(fission) secure a reiuvenescence for the indiridual. The less differentiated individual is on the whole the younger one. Are we not justified in concluding that the undifferentiated parthenogenetic egg produces a daughter agamic inaividual because this egg is the more simple, 1.e., younger, while the more highly differentiated egg grows into the cercaria because it is physiologicaliy old? Interpretec in this light, the parthenitic individuals of the Digenea are physiologically younger than the cercariae and the adult gametic forms because their structure is simpler. They have sacrificed complexity of structure to meet the needs of parasitic life, and in so doing have become remarkably rejuvinated. In two species, Cercaria diaphana and C. microcharynx, extreme simplicity has been assumea in the sporocyst, since the germ balls may develop from any cells of the body wali.

The witer believes that the ability of the parthenita to reprouce daughter rediae or sporocysts for two or more generations rests on the simplicity of the uvum are the relative simplicity of the parthenita, especially as regards the undifferentiated mesoderm cells. If this rejujenation can be continued indefiniteIy, there is no reason to believe that the parthenogenetic generations could continue indefinitely without the intercalation of the gametic cycle. 

Chila (1915: 407) has 8tated that "1n many cases parthenogenetic eggs are apparently less highly differentiated morphologicully, and younger physlologically, than zygogenic egge of the same species." we present study makes it necessary to ada that in cases where the parthenogenetic egrs may develop into either daughter parthenitae or cercariae, the egss which develop into the former individuals are apparently less highly differentiated morphologically and younger physiclogically than those which develop into cercariae.

Finally, the present study causes the writer to supoort the view that the gametic cycle of the Digenea is the more primitive, or at least more closely related to the ancestral group. This conclusion is based on the belief that the criginal tyoe was a highly complex platyhelmia, with a ciliary integument and eye-spots. These characters are found only in the miracidium, a larva produced from a material most nearly prototypic of the entire lifehistory. Even the tail, which is a median posterior adatation to swimming life, has become non-functional in many grcups. The modification of the parthenitae has come about as the jirect result of parasitism. The assunption of a cylindrical form is secondary. 



\section{VIII, Sumary}

1. Altho the fauna of the Bitter foot Valley is restricted to few species, fourteen species of agamic trematodes have been found in the vicinity.

2. The history of the germ cells of the sporocyst and reaia show Farthenogenesis to obtain in these inaividuals.

3. Parthenitae ans aault trematodes are comparable inaividuals: their germ cells can be referred to a common type of germinal epitheliun.

4. The integument of trematoles is mesodermal in origin.

5. The fundamental systems of the adult trematode are well developed in the cercariae.

6. The excretory, genital and nervous systems of the cercariae may be used to show the natural relationships of the larvae. 7. Monostomes are probably polyphyletic.

8. Digenea, tozether with Monogenea, are nore closely related to the Turbeliaria than to any otiner group.

9. Parthenitae are well adapted to their parasitic life because they are morphologically simple and physiologically young. 



\section{Literature Cited.}

André, J.

1910. Zur Morphologie des Nervensystems von Polystomum

integerrimun Froel. Ze1t. w1ss. Z001.,95:191-220; 13 textfigs. Balfour, F.M.

1881. A Treatise on Comparative Embryology. vol. II. London. $655 \mathrm{pp}$.

Barker, F.D., and Laughlin, J.W.

1911. A New Species of Trematode from the Muskrat, Fiber

zibeth1cus. Trans, Amer. Micr. Soc, 30:261-274: 1 pl.

Bettendorf, $\mathrm{H}$.

1897. Ueber Musculatur und Sinneszellen der Trematoden. Zool. Jahrb., Anat., 10: 307-357; 5 Taf.

BIanchard, '́.

1847. Recherches sur l'organization des vers. Ann. Sc1. Nat.,

2001. (3) 8:271-341; $5 \mathrm{pl}$.

Blochmann, T.

1896. Die Epithelfrage bei Cestoden und Trematoden. Sep. 6ten versa, deutschen Zool. Ges, zu Bonn, Iz pp.,z Taf. Hamburg. Bovaird, D., and Cecil, R.I.

1914. Schistosomiasis japonica; a Clinical and Pathological Study of Two Cases. Amer. Jour. Med. Sci.,148: 187-205;3 figs. Brandes, G.

1891. Die Familie der Holostomiden. Zool Jahrib., Syst.,5:

$547-604 ; 3$ Taf.

1892. Zum feineren Bau der Trematoden Zeit. wiss. Zool.,

53: 558-577; 1 Taf.

Braun, M.

1893. Vermes. Trematodes. Bronn's Thierreich,IV,IA,Pp.306-925. 

1901. Zur Revision der Trematoden der Vögel.I. Centralbl. Bakt. u. Parasit., I. ,29:560-568.

1901a. Zur Revision der Trematoden der Vögel.II. Centralbl. bakt. u. Parauit., I.,ลิs: 895-697,941-948.

Cary, L,R.

1909. The Life History of Diplodiscus temporatus Stafford. With Especial Reference to the Development of the Parthenogenetic Eggs. Zool. Jahrb., Anat., 28: 595-557; 4 pl.

Child, C.M.

1915. Senescence and Rejuvenescence. Chicago. $481 \mathrm{pp}$. Coe, W.R.

1896. Notizen über den Bau des Embryos von Distomum hepaticum. Z001. Jahrb., Anat., 9: 561-570; I Taf.

Cort, W. W.

1914. Larval Trematodes from North American Fresh-Water Snails. Jour. Parasit., 1:64-84;13 f1gs.

1915. Some North American Larval Trematodes. Ill. Biol. MonOgr., 1:447-532; $8 \mathrm{pl}$.

Dietz, E.

1910. Die Echinostomen der Vögel. Zool. Jahrb., Suppl.,

$12: 265-512 ; 6$ Taf.

Ercolani, G.

1881. Dell' adattemento della specie all' ambiente. Nuove ricerche sulla storia genetica dei Irematodi.I. Mem. I. Acc. Ist. Bologna, (4)a:239-334;3 Tav.

1882. Dell' adattemento della specie all' ambiente. Nuove ricerche sulla storia genetica del Trematodi. II. Mem. r. Acc. Ist. Bologna., (4) 3: 43-111; 3Tav. 

Fantham, H.B.

1916. The Animal Parasites of Man. London. $900 \mathrm{pp}$. Faust, E.C.

1917. Notes on the Cercariae of the Bitter Root Valley, Montana. Jour. Parasit., 3 :105-123; 1. pl.

de Filippi, $\mathrm{Ph}$.

1857. Troisième Mémoire pour servir à I'histoire génétique des Trématodes. Mém. Acad. Sci. Turin,, (2)18:1-34;3 pl. Fischer, P.M.

1883. Ueber den Bau von Opisthotrema cocleare nov. genus., nov. spec. Zeit. wiss. Zool.,40:1-42; 1 laf. Gaffron, E.

180ิ. Zum Nervensystem der Trematoden. Schneider's Beitr., 1:109-115; 1 Taf.

Goto, S.

1893. Der Laurer'sche Kanal und die Scheide. Centralol. Bakt. u. Parasit., I.,I4:797-801; 4 figs.

1894. Studies on the Ectoparasitic Trematodes of Japan. Jour. Coll. Sci. Imp. Univ. Japan., (1)8:1-273; 27 pl. Haswel1, W. A.

1888. On Temnocephala, an Aberrant Monogenetic Trematode. Quart. Jour. Micr. Sci.,28: 279-302; 3 pl.

1903. On Two Remarkable Sporocysts Occurring in Mytilus latus on the Coast of Nis Zealand. Proc. Linn. Soc. N.S. Wales. ,27:494-515;2 pl.

Hausmann, I.

1897. Über Trematoden der süsswasserfische. Rev. suisse 2001.,5:1-42;1 Taf. 

Hesse, R. 1897 .

untersuchungen über die Organe der Llchtempflndung bel nlederen Ihieren.II.D1e Augen der Platyhelminthen. Ze1t. W1ss. Z0ol., $62: 527-582 ; 2$ Taf.

Hofmann, $\mathrm{K}$.

1899. Beitraege zur Kenntnis der Entwicklung von Distomum leptostomum 01sson. Z001 Jahrb., Syst.,12:174-204; 2 Taf. Jägerskiöld, L.A.

1891. Ueber den Bau des Ogmogaster plicatus(Creplin). Kgl. svenska Vetensk. Akad. Handl., (7) 24: 1-32;2 Taf. Johnston, S.J.

1904. Contributions to a Knowledge of Australian Entozoa. III. On Some Species of Holostomidae from Australian Birds. Proc. Linn, Soc. N. S. Nales, 29:108-116;3 pl. Juel, H.

1889. Beitraege zur Anatomie der Trematodengattung Apoblema (Dujara). Kgl. svenska Vetensk. Akad. Handl.,(4)15: 1-46;ITaf. Katsurada, F.

1914. Schistosomiasis japonica. Centralbl. Bakt. u. Parasit. I, 72: 363-379; 2 Taf. Kowalewski, M.

1895. Studya helminthologiczne. III. Bilharzia polonica,n.sp. Rozpraw Wydz, mat.-przyr. Akad. Umiejet. Krakowie., (I) 31: $1-30 ; 2 \mathrm{Tab}$.

1896. Studya helmintholoczne. IV. Bilharzia polonica, n. sp. Rozpraw Wydz, mat.-przyr. Akad. Umiejet. Krakowie.,(1) 30: $1-12$.

1896a. Études Helminthologiques.IV. Amendements et Suppléments au travail de l'auteur sur le Bilharzla polonica sp. nov., 

Bull. Acad. Sc1. Cracovie, 1896:146-148.

Lang, A.

1880. Untersuchungen zur vergleichenden Anatomie und H1stologie des Nervensystems der Platyhelminthen. II. Ueber das

Nervensystem der Trematoden. Mith. Zool. Sta. Neapel,z:z8-52;

3 Taf.

1884. Die Polycladicien des Golfes von Neapel. Fauna u.

Flora von Neapel, (2) $11: 1-669 ; \mathrm{pl}$.

Lankester, E.R.

1901. A Treatise on Z0010gy. IV. The Platyhelmia, Mesozoa, and Nemertin1. London. 204 pp.

La Rue, G.R.

1917. Two New Larval Trematodes from Thamnophis marciana and Thamnophis eques. Occasional Papers Kus. Zool. Univ. I1ch., 35:1-14; 1 pl.

La Valette, St George.

1855. Symbolae ad Trematodum Evoluticnis Historiam. Berolini. $40 \mathrm{pp} ., 2$ Taf.

Lebour, Marie V.

1907. Larval Trematodes of the Northumberland Coast. Trans,

Nat. Hist. Soc. Northumberland, n.8.1:437-454;5 pl.

Leidy, J.

187\%. On Flukes infesting Mollosks. Proc. Acad. Nat. Sci. Phila., 29: 200-202.

1890. Notices on Entczoa. Proc. Acad. Nat. Sci. Phila. $42: 410-418$.

1904. Researches in Helminthology and Parasitology.

Smiths. Inst. Misc. Co11. 1477. $281 \mathrm{pp}$. Leiper, R.T. 

1915. Report on the Results of the Bliharzia 118 icn in

Egypt, 1915. III. Jour. R. Army Ked. Corps,25:253-267;15 f1g8. 1916. On the Relation between the Terminal-Spined and the Lateral-Spined Eggs of Bilharzia. Brit. Med. Jour.,1916 (1): 411.

Leiper, R.T., and Atkinson, E.L.

1915. Observations on the Spread of Aslatic Schistosomiasis. Brit. Ned. Jour, ,1915(1): 201-203;1 pl.

Lejtenyi, Th.

1881. Ueber den Bau des Gastrodiscus polymastos Leuck.

Abhandl. Senkenberg, naturf. Ges. Frankfort,1z:1z5-146;3 Taf. Leuckart, R.

1863. Die Menschlichen Parasiten. Leipzig. $766 \mathrm{pp}$.

1886. Die Parasiten der Menschen. 2 Aufl. I, Trematodes.

Leipzig u. Hoidelb. $534 \mathrm{pp}$.

Leyig, Fr.

1853. Helminthologische Notizen, Zeit. wiss. Zool.,4:382384. Lindner, $E$.

1914. Ueber die Spermatogenese von Schistosomum haematobium Bilh. (Bliharzia haematobla Cobb.), mit besonderer Berücksichtigung der Geschlechtchromosomen. Arch, f. Zellforsch.,12: 516-538; 2 Taf.

Linstow, 0 .

1877. Enthelminthologica. Arch. Naturgesch. (I) 43:173-19,;

3 Taf.

Looss, A.

1885. Beiträge zur Kenntn1s der Trematoden. Zeit. 四ss. Z001.,41:380-446;1 Taf. 

1892. Ueber Amphistomum subclavatum Rud. Leuckart's Festschr. 142-167; 2 Taf.

1893. Zur Frage nach der Natur des Körperparenchyms be1 den Trematoden. Ber. d. K. Sachs. Ges, wiss, mat.-phys.Cl., Sitz, 9 Jan. 1893, 10-34.

1893a. Ist der Laurer'sche Kanal der Trematoden eine Vagina? Centralbl. Bakt. u. Parasit., I,13:808-819;4 flgs.

1894. Die Distomen unserer Fische und Frösche. Bib. Zool., 16: 1-296; 9 Taf.

1895. Zur Anatomie und Histologie von Bilharzia haematobia (Cobbold). Arch. Mikr. Anat.,43:1-108; 3 Taf. 1896. Recherches sur la Faune parasitaire de l'Égypte. Première partie. Mém. I'institute Égyptien, 3: 1-252; $16 \mathrm{pl}$. 1899. Veitere Beiträge zur Kenntnis der Trematoden-Fauna Aegyptiens. Zool. Jahrb.,Syst.,12:521-784; 9 Taf. 1913. Die Bilharzia Krankheit. Handbuch der Pathogenen Mikroorganismen, 2 Aufl., 1-2z.

Lortet et Vialleton, I.

1894. Etude sur le Bilharzia et la Bilharziose. Ann. de I' Univ. de Lyon, (I)9. I24pp. Cited by Looss 1895.

Lïhe, M.

1909. Parasitische Plattwirmer.I. Trematodes. Süsswasserfauna Deutschlands, $218 \mathrm{pp}$. Jena. Mathews, A.P.

1915. Physlological Chamistry. New York. $1040 \mathrm{pr}$. Minot, C.S.

1897. Cephalic Homologies. A Contribution to the Determination of the Ancestry of the Vertebrates. Amer. Nat, 31:927-943, 

Montgomery, R.E.

1906. Observations on Bliharziosis among Antmals in India.

Jour. Trop. Vet. Sc1.,(1) $1: 1-32,(1) 2: 1-37 ; 4 \mathrm{pl}$.

Monticelii, Fr. Sav.

1892. Cotylogaster michaelis nov. gen., nov. spec. Leuckart's Festschr, ,164-214; 2 Tav.

1914. Ricerche sulla Cercaria setifera di Joh. Mülier. Ann.

del Kus. zool. della Univ. di Napoli, (4)4:1-49; 5 Tav.

Moulinie, J.J.

1856. De la Reproduction chez les Trématodes Enàoparasites.

Mem. de I'Institut Genevois, $3: 1-280 ; 6 \mathrm{pl}$.

Nitzsch, Ch. L.

1807. Seltsame Lebens- und Todesart eines bisher unbekannten Wasserthierchens. Kilian, Georgia, 257-z62; 281-286. Cited by Braun 1893.

1816. Beltrag zur Infusorien-kunde der Naturbeschreibung der Zerkarien und Bazillarien. Neue Schrift. d. Nat. Ges. Halle (1) 3; I Taf. Reviewed in Is is 1818.

Nordmann, A. V.

1832. Mikrographlsche Beiträge.I. 118 pp. 10 Taf. Berlin. odhner, T.

1907. Zur Anatomie der Didyrozoen: ein getrenntgeschlechtlicher Trematode mit rudimentaren Hermaphroditismus. Z0ol. Studien Tullberg, 1907:309-342; I Tar.

1910. Gigantobilharzia acotylea, n.g., n.sp., ein mit den Bilharzien verwandter Blutparasit von enormer Lange. Zool. Anz., 35:380-385; 5 figs.

1912. Zum natürI1chen System der digenen Trematoden.V. Z001. Anz, 41: 54-71; 7 figs. 

Pagenstecher, H.A.

1857. Trematodenlarven und Trematoden.

Parona, C., e Ariola, V.

1896. Bilharzia Kowalewskii n. sp. nel Larus melanocephalus.

Boll. dei Mus. di Zool. e Anat. Conp. della R. Univ. di Genova,

$45: 1-3$.

Pourier, J.

1886. Trématodes nouveaux ou peu connus. Bull. de la Scc.

Philomath. de Paris. Seance du 28 Nov. 1885, $21 \mathrm{pp}, 4 \mathrm{pl}$.

Pratt, H.S.

1909. The Cuticula and Subcuticula of the Trematodes and

Cestodes. Amer. Nat.,43:705-729; pl.

Rettger, L.J.

$$
\text { of the Anatomy }
$$

1897. Some Additions to our Knowledge ${ }_{n}$ and Embryology of the Holostomidae. Proc. Ind. Acad. Sc1.,1896: 224,225.

Reuss, H.

1903. Beobachtungen an der Sporocyst und Cercaria des

Distomum duplicatum, Zeit. wiss, Zool, , 74: 458-477.

Rossbach, E.

1906. Beiträge zur Anatomie und Intwicklungsgeschichte der

Redien, Ze1t. wiss, Zoc1., 84: 361-445; 4 Taf.

Rosseter, T.B.

1909. On Holostomum excisum (Lingtow,1906) and the Develop-

ment of the Tetracotyliform Larva to a Holostomum sp.

Jour. Quek. Micr. Cluo, (2) 10:385-392; 1 pl.

Ruỉolphi, C.A.

1819. Entozoorum Synopsis. Berlin. $812 \mathrm{pp}$.

Schauinsland, $\mathrm{H}$.

1883. Beiträge zur Kenntnis der Embryolanentwicklung der 

Trematoden. Jena. Ze1t. Naturw185.,16: 435-527; 3 Taf. Schmarảa, L.K.

1871. Zoologie. vol.I. Wien. $372 \mathrm{pp}$.

Schneider, A.

1864. Ueber die ifuskeln der Würmer und inre Bedeutung fur das System. Arch. Anat. u. Physiol, ,1864: 590-597. Schulze, M.

1853. Zoologische Skizzen. Ze1t. Wiss. Zool, 4: 178-195. Schwarze, W.

1886. Die postembryonale Entwicklung der Trematoden. Zeit. wiss, Zool., 43: 41-86; I Taf.

Siebola, $T h . v$.

1835. Helminthologische Beiträge. I. Arch. Naturgesch. (I)I: $45-83 ; 1$ Taf.

Ssinitzin, D.Th.

1905. Distomes des polssons et des grenouilles des environs de Varsovie. Materiaux pour I'histoire naturelle des Trématodes. Mem. soc. nat. Varsovie, Biol., 15: 1-z10; $6 \mathrm{pl}$. 1910. Studien über die Phylogenie der Trematoden. Biol. Zeit.,I: 1-63; 2 Taf.

1911. La génération parthénogénétique des Trématodes et sa descendance dans les mollusques de la Her Noire. Mém. Acad. Sc1. St. Petersbourg, (8) 30: 1-127; $6 \mathrm{pl}$.

Steenstrui, J.J.S.

1842. Ueber den Generationswechsel oder die Fortpflanzung und Entwicklung durch abwechselnde Generaticnen. Copen.60 pp. Stiles, Ch. W., and Hassall, A.

1908. Index Catalog of Medical and Veterinary Zoology. 

Trematoda and Trematode Diseases. Treas. Dept. Pub. Health and Marine Hosp. Serv. U.S. Hyg. Lab. Bull. 37. 401 pp. Surfaoe, F.M.

1907. The Early Development of the Polyclad, Planocera 1nqu1lina. Proc. Nat. Acad. Sci. Phila.,59: 514-559; 6 pl.

Tennent, D.H.

1906. A Study of the L1fe History of Bucephalus haimaenus:

a Parasite of the Oyster. Quart. Jour. Micr. Sc1.,n.8, ,44: 99-133; $2 \mathrm{pl}$.

Thomas, A.P.

1883. Life History of the Liver Fluke. Quart. Jour. Micr. Sci., 23: 99-133; 2 pl.

Thoss, E.

1897. Ueber den Bau von Holostomum cuculius nov. spec. Leipzig. 66 pp., 2 Taf.

Ward, H.B.

1909. Fasciolopsis buskii, F. Rathouls1, and Related Species in China, Trans, Amer, Micr. Soc., 29: 5-16; 2 pl.

1916. Notes on Two Free-Living Larval Trematodes from North America. Jour. Parasit.,3:10-20; 1 pl.

Wright, $S$.

1912. Notes on the Anatomy of Microphallus opacus. Trans. Amer. Micr. Soc.,31:167-176; $2 \mathrm{pl}$.

Za1ler, 0 .

1914. Zur Kenntnis der Anatomie der Muskulatur und des Nerversystem der Trematoden. Zool. Anz.,44:385-396; 3 figs. 

ad

al

as

av

b

bl

br

ca

c

ceg

c g

cr

cs

dc

$81 \mathrm{c}$

ap

ds

d.

e

ec

eg

eh

ep

es

et

ex

ev

fc

$\mathrm{g}$

gb

glc

$i$

igl

$1 \mathrm{c}$

Ie

1

Ig

Im

Ip

18

$m$

me

$m p$

$n$

ne

$n p$

nph

ns

nt

od

$\circ$ anterior dorsalis nerve

anterior lateralis nerve

anterior sensory field

anterior ventralis nerve

bursa, genital atrium

bursa glands

corebral ganglion

caudal pocket

cecum

cercaria germ-ball

caudal gland cells

clrrus pouch

collar spines

dorsal commissure

dorsolateral commlssure

profundus of the dorsalis nerve

superficialis of the dorsalis nerve

salivary gland duct

epithelium

ectoderm

excretory granules

evertible prepharynx

excretory pore

esophagus

excretory tube

excretory tubule

excretory vesible

flame cell

genital pore, birth pore

germ-bali

cystogenous cell

intermedius nerve

digestive glands

Laurer's canal

lateral eye

longitudinal muscle cell

localized germinal epithelium

longitudinal muscle fiber

posterior locomotor pocket

lateral suctorlal groove

myoblast

median eye-spot

musculus preoral is

nerve celi

nerve ending

nervus palatinus

pharyngealis nerve

subesophageal commissure

nerve trunk

oviduct

ovum 



\section{Abbreviations (continued)}

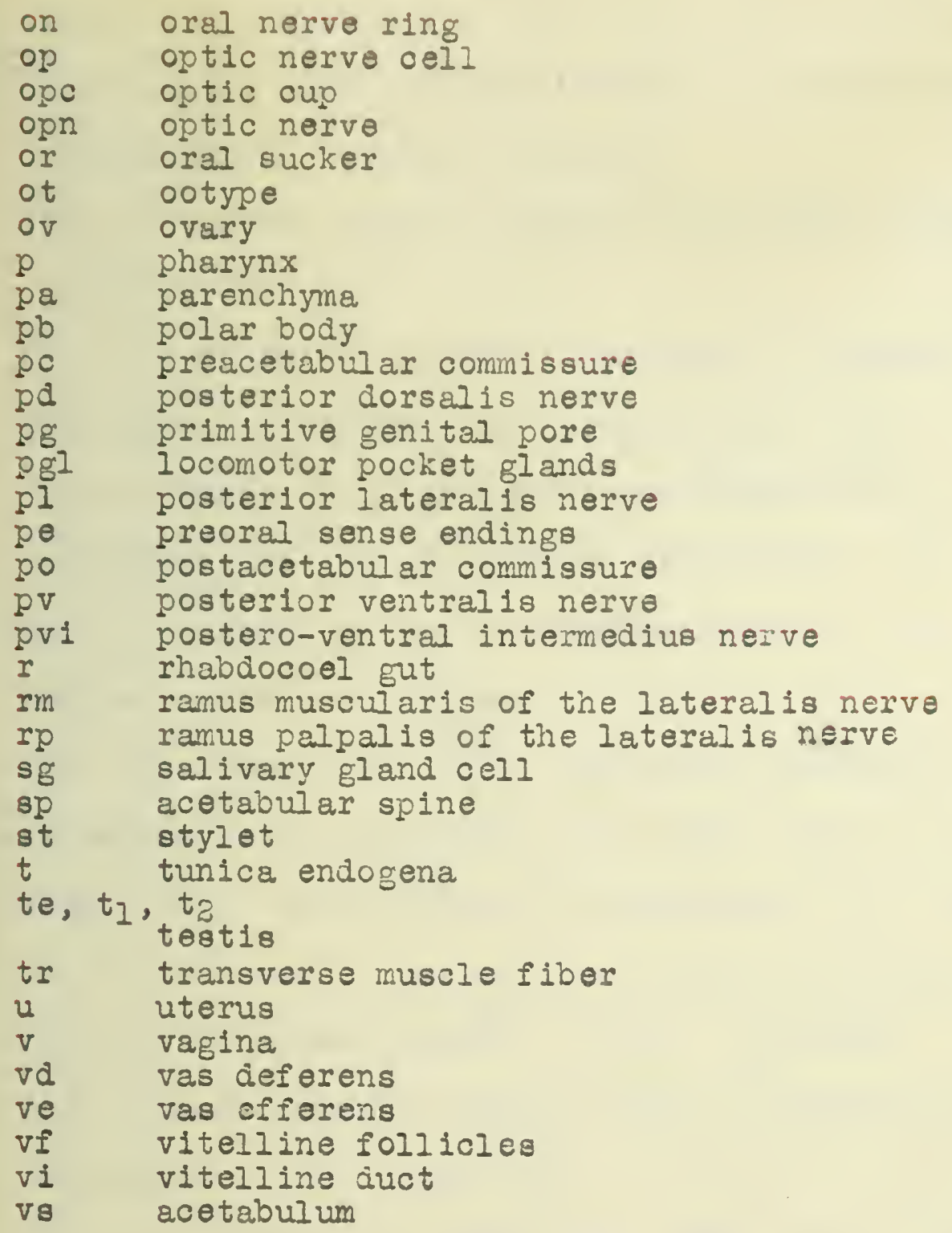

Note. - The number in parenthesis after each figure explanation represents the value of the line lrawn next to each figure in the rlate, expressed in millimeters. 

Plate I.

Figs.1,3,3.- Sketches of the progressive plementation of Cercarla pellucida, dorsal view; showing two lateral eye-spots and one median spot. $\quad x$ 100. $(0.05 \mathrm{~mm})$.

Fig. 4.- Dorsal view of Cercaria pellucida, somewiat contracted. $x$ 100. $(0.05 \mathrm{~mm})$.

Fig. 5.- Anterior tip of C. pellucida, flgting details of pizmentation and contents of the excretory tubes. $\times 330 .(0.01 \mathrm{~mm})$. Fig.6.- Redia of C. pellucida, characterized by the extensive rhabdocoel gut and the spinous prepharynx. $x 34 .(0.5 \mathrm{~mm})$. Fig. 7.- Detall of the spinous prepharynx of the redia of C.pelIuc1da. $\times$ 540. (0.01 mm).

Fig. 8.- Young redia of C. pellucida; precocious development of cercariae before the redia is mature. $\mathrm{x} 38 .(0.05 \mathrm{~mm})$. Figr. 9-11.- Three stages in encystment of $\mathrm{C}$. peliucida. $\mathrm{x} 38 .(0.05)$. Fig. 12.- Young C. pellucide; orogin of posterior locomotor pockets with in the caudal pocket. $x 170 .(0.05 \mathrm{~mm})$. Fig. 13.- Transverse section thru the middle of the body of $C$. pellucida. $\times 330 .(0.01 \mathrm{~mm})$.

F1g. 14.- Detail of cystogenous gland cells in the region of the lateral eye-spot of C. pellucida. $x 330 .(0.01$ miri $)$.

Fig. 15.- Contracted excretory bladoer and posterior locomotor pockets of C. peIlucida. $x 238(0.01 \mathrm{~mm})$.

Figs. 16,17.- Detalis of the posterior locomotor pocket of C. pelIucida; fig. 16, contracted; fig. 17, relaxed; xx, retractor muscles, yY, reflexor muscles. $x 540 .(0.01 \mathrm{~mm})$. Fig. 18.- The genitalia of C. pelluciaa; region of ootype and metraterm. $x 238 .(0.05 \mathrm{mrn})$. 

Fig. 19. - Transverse section thru tall of C. pellucida; ordinary parenchyma oells lining excretory lumen. $x$ 540. (0.01 mm). Fig. 19,A.- Oblique section thru tail of C. pellucida, indicatIng arrangement of muscle fibers. $x$ 540. (0.01 mra). F18. 20.- Sagittal section thru pharynx and reaia of C. pellucida, with spinose prepharynx organ retracted. $\quad$ s $330 .(0.01 \mathrm{~mm})$. Fig. 21.- Transverse section thru body of $C$. konadensis in region of posterlor locomotor pocket glands. $x 170 .(0.05 \mathrm{~mm})$. Fig. 22.- Pptical view of the proliferation of germ-balls from the posterior geminal epithelium of the redia of C. pellucida. $x$ 330. $(0.05 \mathrm{~mm})$.

Fig. 23. - Central nervous system of C. pellucida; type system for the trioculate specias of Monostomata cercariae. $x 330 .(0.05 \mathrm{~mm}$ ) Fig. 24.- Oblique section thru ganglion mass, showing connection of eye-spots with brain center; from young Cercaria pellucida. x 330. $(0.05 \mathrm{mr})$.

Fig. 25. - Dorsal view of Ceroaria konadensis. x 105. (0.05 mm). Fig. 26. - Fedia of C. konadensis. $\times 34 .(0.5 \mathrm{~mm})$. Fig. 27. - Detail of a paired group of caudal gland cells of $C$. konadensis, $x$ 540. $(0.01 \mathrm{mra})$.

Fig. 28. - Genital cell masses of C. konadensis in region of ootype. x 540. $(0.01 \mathrm{~mm})$.

Fig. 29.- Detall of excretory bladder and posterior locomotor pockets of C. konadensis. $x$ 238. (0.01 mm.). Fig. 30.- Optical view of the germinal rachis of the redia of C. konadensis. $\times 330 .(0.05 \mathrm{~mm})$. Fig. 31.- Sagittal section thru aspinose prepharynx of the redia of C. konadensis. $x 330$. (0.01 mm). 

F1g. 33.- Tranbverse section thru tall of mature C. urbanens1s Cort, showing caudal gland cells. $\times 330 .(0.01 \mathrm{~mm})$.

F1gs. 33,34.- Stager in eifferentiation of caudal gland cells of C. urbanensis from ordinary parenchyma cells. x 330. (0.01 mm). Fig. 35.- Detail of excretory system vesicle and posterior locomotor pockets of $\mathrm{C}$. urbanens1s. $\mathrm{x} 238 .(0.05 \mathrm{~mm})$. F1g. 36.- Obl1que section thru brain mass and lateral eye-spot, indicating ectodemal origin of pigment cup, and connnection of optic cells with brain; early gern-ball of C. urbanensis. x 730 . $(0.01 \mathrm{~mm})$

Fig. 37. - Frontal section of C. pellucida, 1ndicating detalls of structure near the parenchyma and integument. $x 730.10 .01 \mathrm{~mm}$. Plate III.

F1g. 38.- Ventral view of Cercaria flabeliformis, freed from cyst; 11, lateral 1appets. $\times 80 .(0.05 \mathrm{~mm})$.

Fig. 39.- Dorsal view of C. Ilabelliformis, giving details of the excretory system and genltal system; lat tr., lateral transverse vessel; med tr., median transverse vessel. x 80. (0.05 mm). Fig. 40.- Lateral view of C. flabellifomis, showing the suctorlal cup in the anterior molety of the worm; 11, lateral lappets. $\times 80 .(0.05 \mathrm{~mm})$.

Fig. 4I.- Immature C. flabell1form1s within cyst; 1sg., lateral suctorial groove. X $54(0.05 \mathrm{~mm})$. F1g. 42.- Redia of C. flabelliformis, showing paired sal1vary glands enptying into the oral pocket. $x 54 .(0.05 \mathrm{~mm})$. Fig. 43.- Young reala of C. flabelliformis, deta1ling the excretory channels in the parthenita. $x 54 .(0.05 \mathrm{~mm})$. Fig. 44.- ifid-frontal section thru young âughter redia of 

C. flabelifformis in region of germinal coll maturation. $x 330$. $(0.01 \mathrm{~mm})$

Fig. 45.- Median frontal section thru young daughter redia of C. flabelifformis, showing proliferation of gerninal epitielium at posterior end of gut. $x 330 .(0.01 \mathrm{~mm})$.

Fig. 46.A-M. - Maturation of the parthenogenetic ova of C. flabelIiformis rediae; A, resting cell; B,C, formation of spireme; D, division of spireme skein into elght chromosomes; E,F,G, Iongitudinal splitting of chromosomes at equatorial plate; H, mitosis with formation of polar body; preparation of ovum for second mitosis, before cytoplasmic separation of polar body; $\mathrm{K}, \mathrm{cell}$ cleavage of ovm without cleavage of polar boü, precocious chromosomes, $b_{1}, b_{2}$, excentric; $L$, first cleavage of a cercaria ovum, with polar body degenerating; $M$, metaphase of a somatic cell in process of division. $x 1620 .(0.01 \mathrm{~mm})$.

\section{Plate IV.}

Fig. 47.- Ventral view of Tetracotyle pipientis, showing digestive tract and genital system. $x 105 .(0.05 \mathrm{~mm})$.

Fig. 48.- Diagram of the excretory system of T. pipientis, with excretory granule inclusions. x 105. (0.05 mm).

Fig. 49.- Ventral view of Cercaria ptychocieilus, incliding aigestive, excretory and genital systems. $x 50 .(0.05 \mathrm{~mm})$. Fig. 50. - Sketch of encysted C. ptychocheilus. $x 25 .(0.5 \mathrm{~mm})$. Fig. 51. - Sketch of ruptured cyst of C. ptychocheilus, with attachment arnulus, $x 25 .(0.5 \mathrm{mr})$.

Fig. 52.- Detail of genital system of C, ptychocieilus. x 165. $(0.05 \mathrm{~mm})$

Fig. 53.- Nervous system of C. ptychcche1Ius. x 330. (0.05 rm). 

F1g. 54.- Transverse section thru midale of body of C. ptychocho11us. $\times 540 .(0.01 \mathrm{~mm})$.

F1g. 55.- Dorsal view of Cercaria crenata. x I70. (0.05 mm).

Figs. 56,57. - Ventral and lateral views of stylet of C. crenata. $x$ 540. $(0.01 \mathrm{~mm})$.

F1g. 58.- Sporocyst of C. crenata. x 54..(0.05 mmi).

Fig. 59. - Detall of genitalia of C. crenata. x 170. (0.05 mm).

Fig. 60.- Ventral view of C. glandulosa. x 75. (0.05 mas).

Fig. 61.- Stylet of C. glandulosa, ventral view. x 370. (0.01 mm).

Fig. 62. - Salivary and cystogenous glands of C. glandulosa.

$x 75 . \quad(0.05 \mathrm{mrd})$.

Fig. 63. - Detail of caudal pockets of C. glandulosa, showing insertion of tail, spincse lateral grooves, and three-spined ventral flap. $x$ 100. (0.05 mm).

F1gs.64,65. - Outline of excretory vesicle of C. Glardulosa, open and closed. $x 200 .(0.05 \mathrm{~mm})$.

Fig. 66. - The genital cell masses of C. glandurosa, dorsal view. x 110. $(0.05 \mathrm{~mm})$.

Fig. 67.- Sporocyst of C. glandurosa. $\times 170 .(0.05 \mathrm{~mm})$. Plate V.

Figs. 68-70.- Consecutive frontal sections thru C. glandurosa, giving details of the nervous system anterior to the brain. $x$ 540. $(0.01 \mathrm{mrn})$.

F1g. MI.- Frontal section thru C. glandulosa, with details of innervation of the acetabulum. $\times 540 .(0.01 \mathrm{~mm})$.

Figs. 72-75.- Iransverse sections of C. glandulosa thru levels aa to dd of fig. 60.x 540. (0.01 mra).

Fig. 76.- Ventral view of Cercaria diaphana, considerabiy flattened 

by cover sl10. $x 170 .(0.05 \mathrm{~mm})$.

F1g. 77.- Stylet of C. diaphana, ventral view. $x$ 540. (0.01 nm.) Fig. 78. - Ventral vien of C. diaphana, giving detalls of glands and genital cell masses. $x$ 170. (0.05 mm).

Figs. 79,80.- Sporocysts of C. diaphana. $x 80 .(0.05 \mathrm{~mm})$. Fig. 81.- Ventral view of Cercaria denaritica. x 170. (0.05 mm). Figs. 8స,83.- Lateral and ventral views of the stylet of C.dendritica, $x$ 250. (0.01 min).

Fig. 84.- Encysted c. dendritica. x 150. (0.05 mm).

Fig. 85.- Salivary and cystogenous glands of C. dendritica. xl70. $(0.05 \mathrm{~mm})$.

Fig. 86.- Genitalia of C. denaritica. x 150. (0.05 mr.). Fig. 87.- Young sporocyst of C. dendritica. x 150, (0.05 mm). F18. 88.- Mature sporocyst of C. dendritica. x 150. (0.05m). Fig. 89.- Posterior end of mature sporocyst, showing origin of germ-balls from localized germinal epithellum. $x 330 .(0.01 \mathrm{~nm}$ ). Fig. 90.- Ventral view ô Cercaria micropharynx. x 170. (0.05m). Figs. 91,92.-Ventral and lateral views of the stylet of C.micropharynx. $x$ 540. $(0.01 \mathrm{~mm})$.

Fig. 93.- Distrioution of glands in C. mieropharynx, x 170. (0.05crso), F1g. 94.- Sporocyst of C. micropharynx, with non-localized germinal epithelium. $x$ I70. $(0.05 \mathrm{~mm})$.

Fig. 95.- Cercariae encysted in old sporocyst of C. micropharynx. x 54. $(0.05 \mathrm{rm})$.

Fig. 96.- Genitel cell masses of C. micropharynx. x $170 .(0.05 \mathrm{~mm})$. F1g. 97.- Transverse section thru brain center of C. inicropharynx. $x$ 540. $(0.01 \mathrm{~mm})$.

Fig. 98. - Transverse section thru excretory cornua of C. micropharynx. $x$ 540. $(0.01 \mathrm{~mm})$. 

Fig. 99.- Transverse section thru tall of C. micropharynx. $x$ 540. (0.01 mm).

Fig. 100.- Ventral view of Cercaria racemosa. x 150. (0.05 mm). Figs. 101,102.- Ventral and lateral vieins of the stylot of C. racemosa. $\times 330 .(0.01 \mathrm{~mm})$.

Fig. 103.- Detail of salivary glands of C. racemosa. x 150. (0.05). Fig. 104.- Genital coll masses of C. racemosa. x330. (0.01 mm). Figs.105.106.- Sporocysts of C. racemosa, showing localized germinal epithel1um and attachment organ,ac. x $54 .(0.05 \mathrm{~mm})$. Fig. 107.- Lateral view of the genital cell masses in the region of the acetabulum, C. racemosa. $\times 330 .(0.01 \mathrm{~mm})$.

Fig. 108.- Optical vien of the sporocyst of C. racemosa in region of birth pore, be; arrom points torard attachment organ. $x 330 .(0.01 \mathrm{~mm})$.

Fig. 109. - Ventral view of Cercaria trisolenata. x 150. (0.05mm). Fig. 110.- Dorsal view of collar spines of C. trisolenata. x 170. $(0.05 . \mathrm{mm})$.

Fig. 111.- Lateral view of collar spines of C. trisolenata, thittysix in number. $x 330 .(0.01 \mathrm{~mm})$.

Fig. 112.- Sketch of acetabular spines of C. trisolenata. $\times 540$. $(0.01 \mathrm{~mm})$.

Fig. 113. - Typical cystogenous cell glands of C. trisolenata, showing cystogenous granuzes and chroraidia. $x$ 540. (0.01 ram). Fig. 114, A-E.- Sketches of the developmental stages of C. trisolenata. $\times 80(0.05 \mathrm{~mm})$. Fig. 115, A-C.- Stages in encystient of C. trisclensta. $x 80$. $(0.05 \mathrm{~mm})$.

Plate VII.

Fig. 116.- Encysted C. trisolenata. x 150. (0.05 mm). 

F18. 11\%.- Redia of C. trisolenata. $\times 50 .(0.05 \mathrm{~mm})$.

Fig. 118,- Longltudinal and transverse muscle fibers of the digostivo tract of C. trisulonata, showirg myoblast comections. $x 730 .(0.01 \mathrm{~mm})$.

Fig. 119.- Peripheral longiturinal muscles of C. trisolenata. $x$ 730. $(0.01 \mathrm{~mm})$.

Fig. 120.- Genital cell masses of C. trisolenata. x 220. (0.05mm). Fig. 121. - "Butterfly stage" in development of the central nervous system of $\mathrm{C}$. trisolenata. $x 330 .(0.01 \mathrm{~mm})$. Fig. 122. - Differentiating stage in dovelopment of the central nervous system of C. trisolenata. x 330 ( $0.01 \mathrm{~mm})$. Figs.123.124. - Lateral and dorsal views of the central nervous system of C. trisolenata. $\times 330$. (0.01 mm).

Fig. 125. - Central nervous system of the redia of C. trisolenata. $\times 220 .(0.05 \mathrm{~mm})$.

Fig. 126. - Distribution of the nerve cells in the redia of $C$. trisolenata, median sagittal section. x 330 . (0.01 mrin). Fig. 127. - Detall of the peripheral nerves of the redia of $C$. trisolenata. $\times 540 .(0.01 \mathrm{~mm})$.

Figs. 128-133. - Transverse sections thru C. trisolenata, at levels al to ff of 1 ig. 109. $\times 330 .(0.01 \mathrm{~mm})$.

$$
\text { Plate VIII. }
$$

Fig.134.- Ventral view of Cercaria biflexa, showing salivary gland cells. $x$ 105. (0.05 min).

F1g. 135. - Ventral view of C. biflexa, showing excretory system. $\times$ 105. $(0.05 \mathrm{~mm})$.

Fig. 136. - Spine collar of C. biflexa, lateral view. x 330. (0.01). Fig. 137.- Redia of C. biflexa. x $170 .(0.05 \operatorname{man})$. 

Fig. 138. - Detall of three flame cells in cephalic region of C. biflexa. $\times 540 .(0.01 \mathrm{~mm})$.

F1g. 139.- Genital cell masses of C. biflexa. x 170. (0.05ma). F18. 140.- Posterior end of redia of C. trisclenata. $x 540$. $(0.01 \mathrm{~nm})$.

Fig. 141.- Posterior end of redia of C. biflexa. $x$ 54C. (0.01 mm). Fig. 142.- Ventral view of Cercaria gracllima. x 230. (0.05). Fig. 143.- Excretory system of C. gracillima. x 350. (0.05 mm). Fig. 144.- Dorsal vien of trumk of C. gracillime. showing eyespots and salivary glands. $x 350$ (0.05 mra ).

Fig. 145.- Detail of flame cell of excretory system of C.eracillima. $x 750 .(0.01 \mathrm{~mm})$.

Fig, 146,147. Sporcoysts of C. gracillima; fig. 146, x 14; fig.147, $\mathrm{x} 21 .(0.5 \mathrm{rm})$.

Fig. 148, A-G.- Stages in development of C. gracillima. $x 50$. $(0.05 \mathrm{~mm})$.

\section{Plate IX.}

Fig. 149.- Genital cell masses of C. grac1llima. x $270 .(0.05 \mathrm{~mm})$. Fig. 150.- Nervous system of C. gracillima. x 540. (0.01 mm). Fig. 151.- Central nervous system in a vory young germ-ball of C. gracilima. $\times 540 .(0.01 \mathrm{~mm})$.

Fig. 15a.- Transverse section thru esophagus glands of C. Gracillima. $x$ 540. $(0.01 \mathrm{~mm})$.

Fig. 153.- Transverse section thru region slightly posterior to that shom in fig. 150 .

Fig. 154.- Transverse section thru salivary glands of C. gracillima. $x$ 540. $(0.01 \mathrm{~nm})$.

Fig. 155.- Ventral view of Cercaria tuberistoma. $\times 1 \% 0 .(0.05 \mathrm{~mm})$. 

F1B. 156, A-F.- Stages in development of C. tuberistoma. $x 75$. $(0.05 \mathrm{~mm})$

Figs. I57, 158.- Sporooysts of C. tuber1stoma. x 54. (0.05 mm). Fig. 159.- Section thru liver tissue of Physa gyrina Say, showing Infection of Cercarla biflexa; a, disintegrating cecum; $\underline{b}$, broken dom connective tissue; c, section of worm. x $170 .(0.05 \mathrm{~mm}$ ). Fig. 160.- Section thru Iiver tissue of Lymnaea proxima Lea, Infected with Corcaria micropharynx; a, fatty bodies in degenerating cocum; $\underline{b}$, vacuoles; , sloughing tissue; $\underline{d}$, karyolysis; e, section of worm. x $170 .(0.05 \mathrm{~mm})$. F18. 161.- Section thru liver tissue of Physa gyrina Say, infected with Cercaria gracillima; a cytolysis; b. fatty globules;

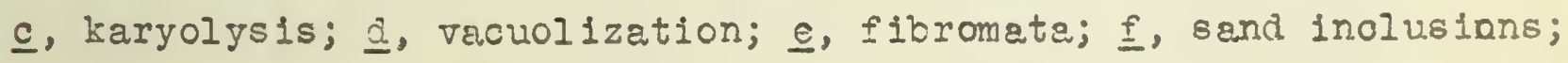
g. section of worm. $\times 240 .(0.05 \mathrm{~mm})$. 



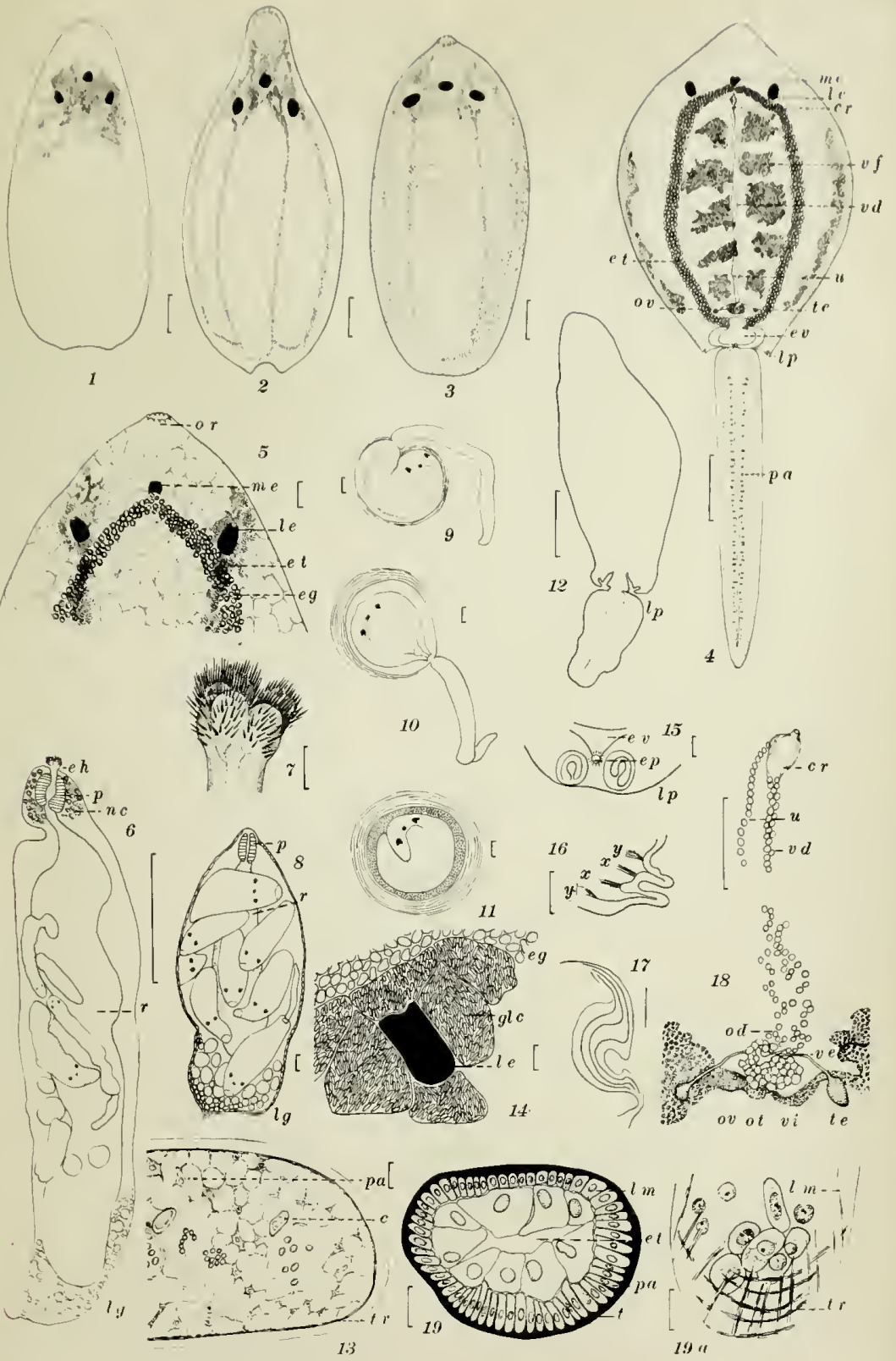

P L A T E I 


$$
\begin{aligned}
& \text { (2) } \\
& \text { (1) the nuto }
\end{aligned}
$$

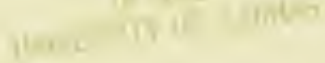




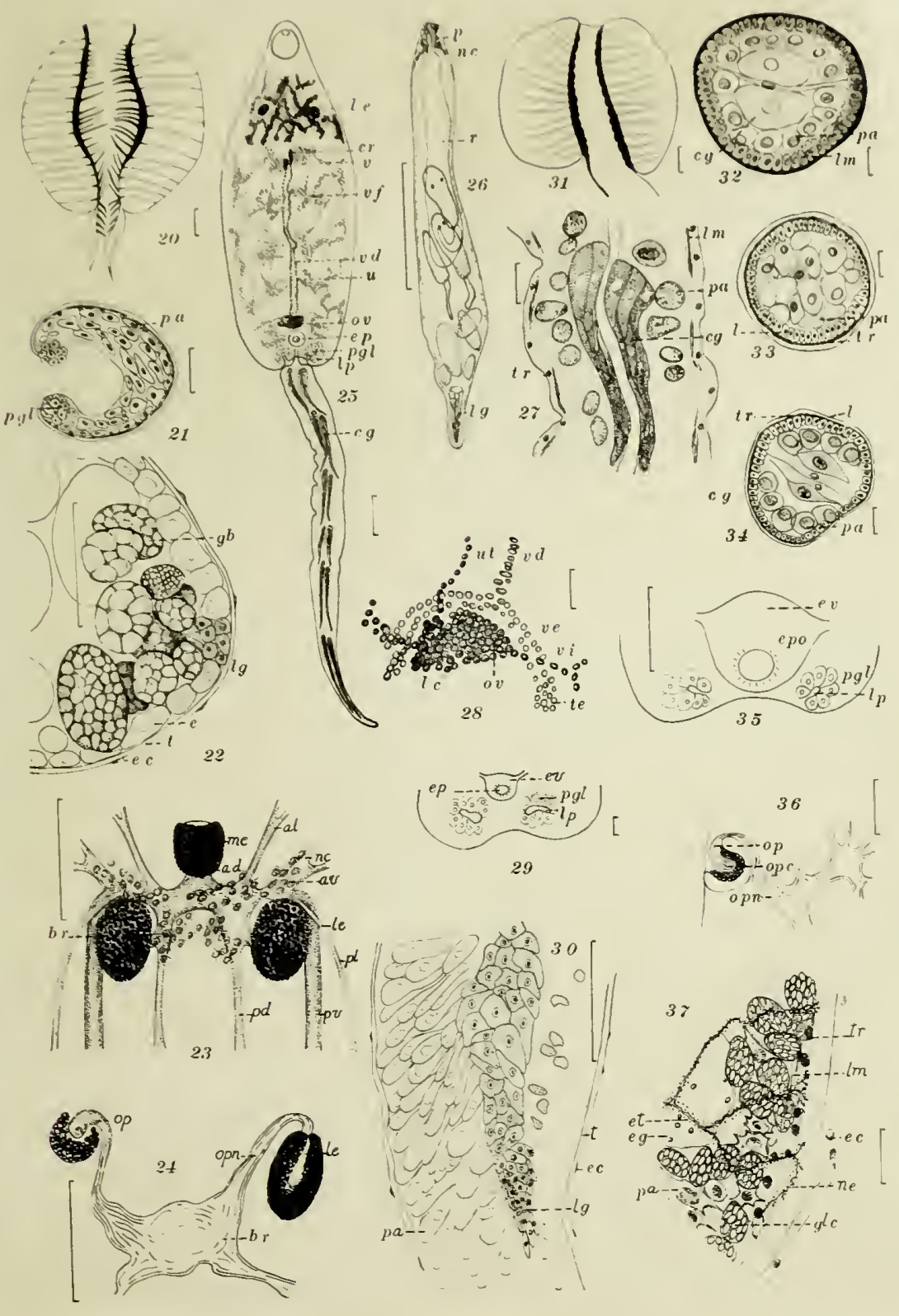

$P I A I I I I$ 


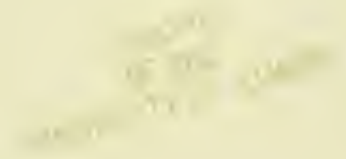




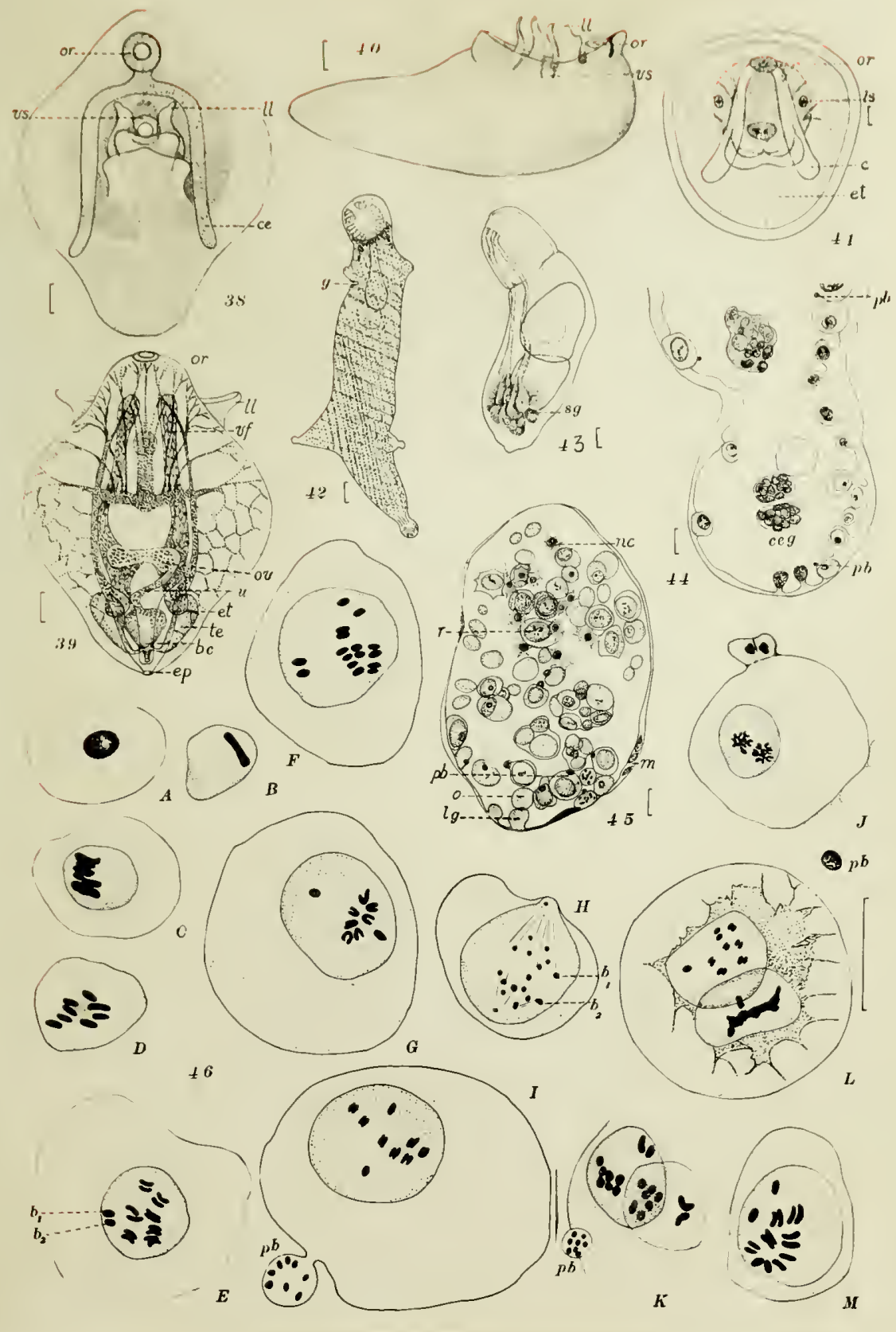

$P$ I $A$ T I I I 



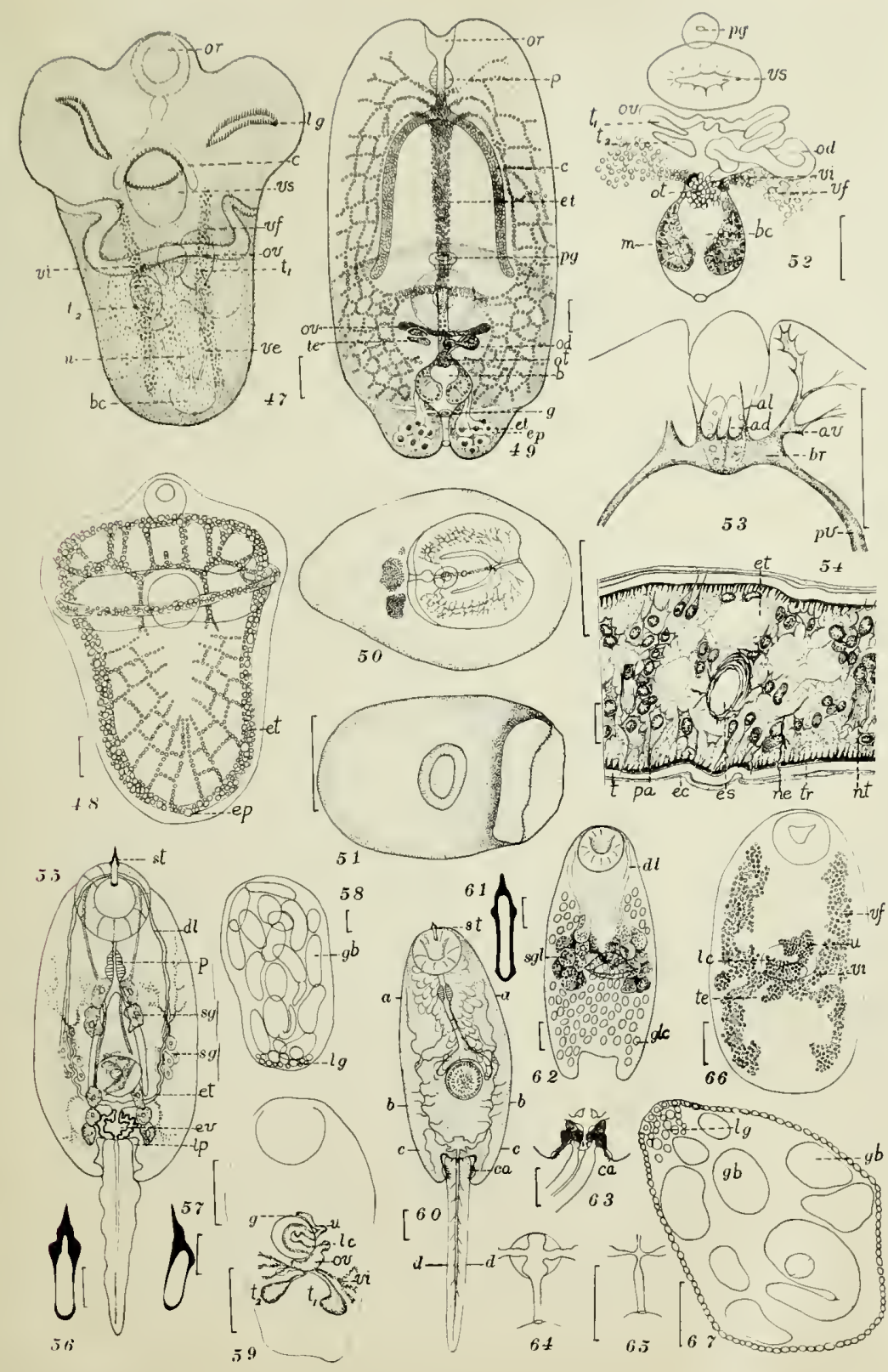





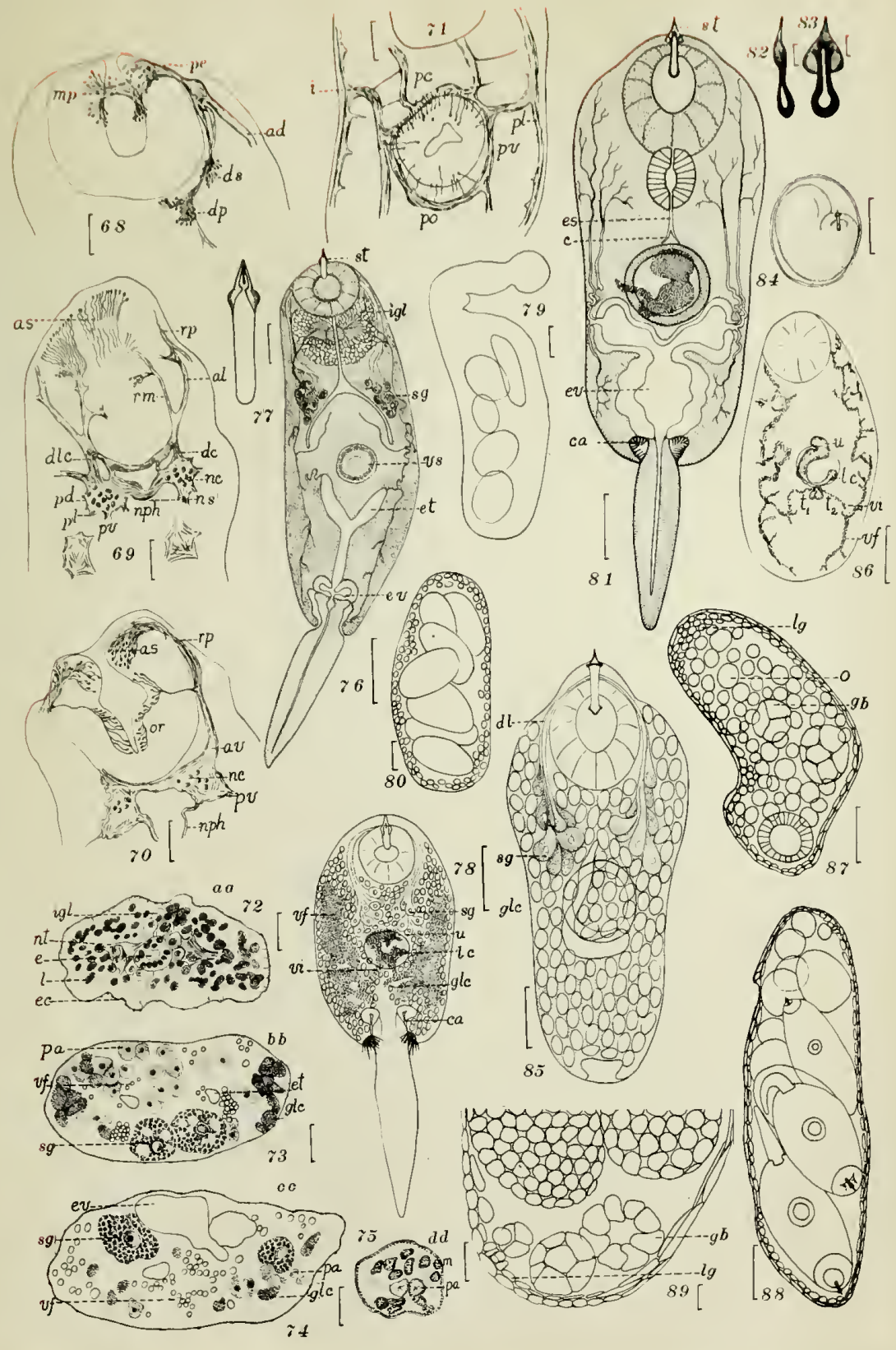


- in

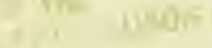




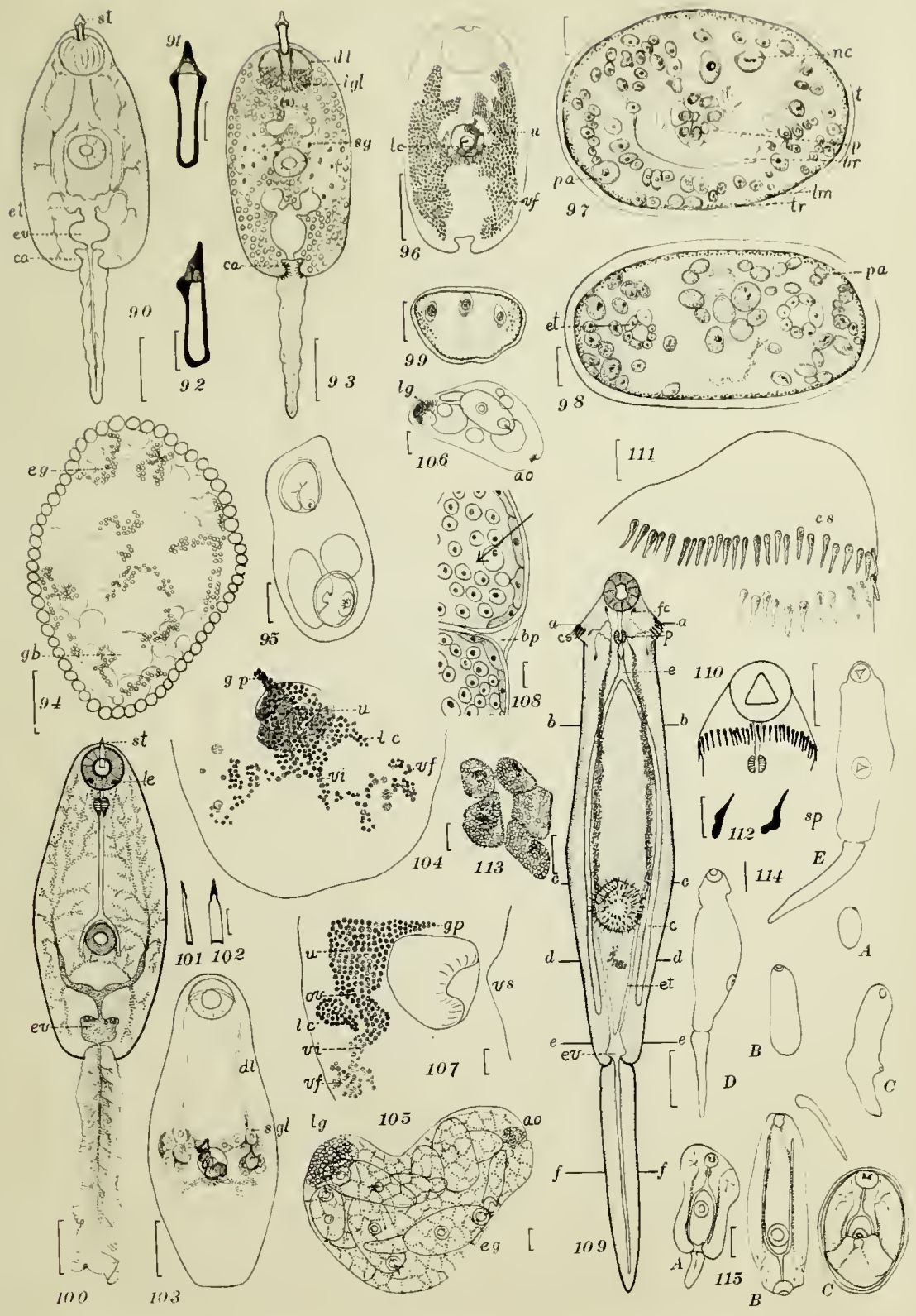




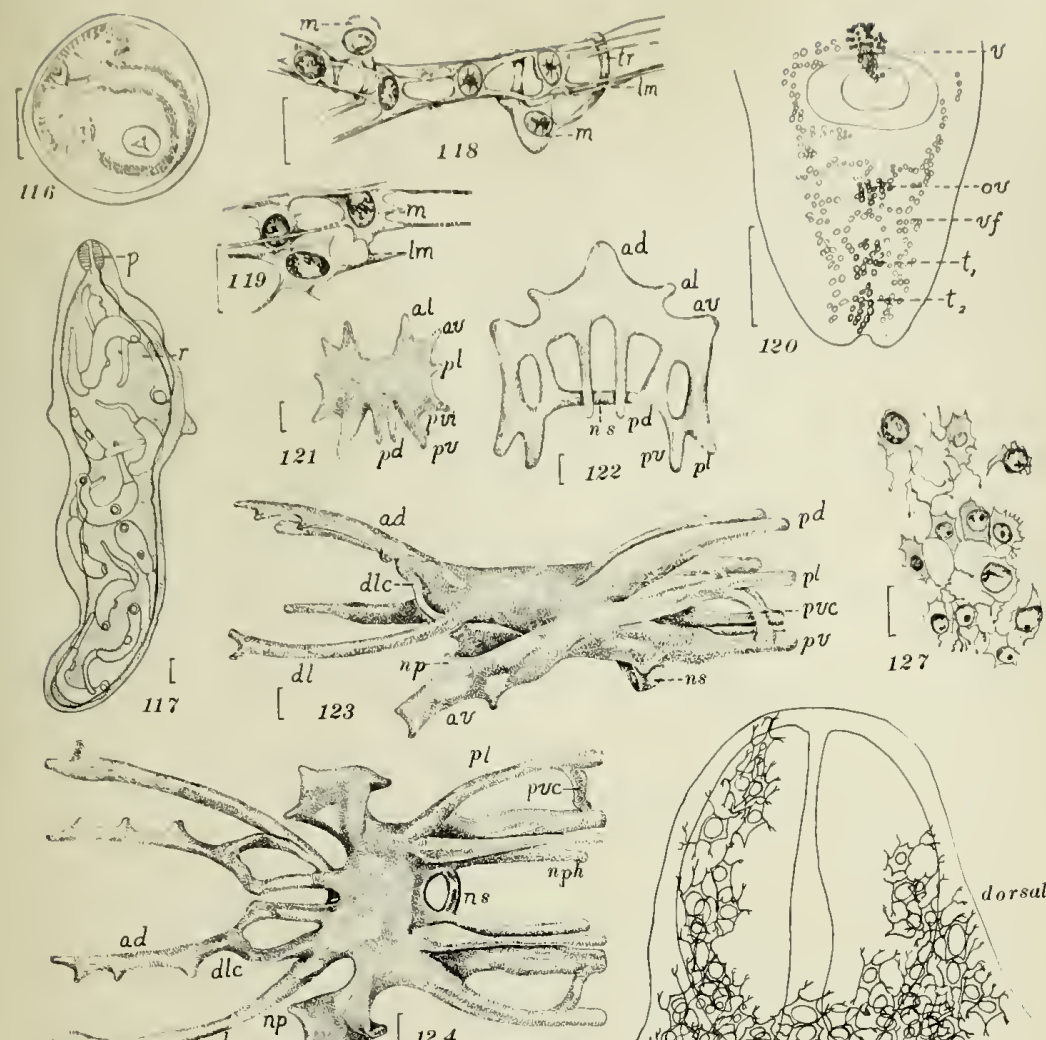

van al av a $[124$
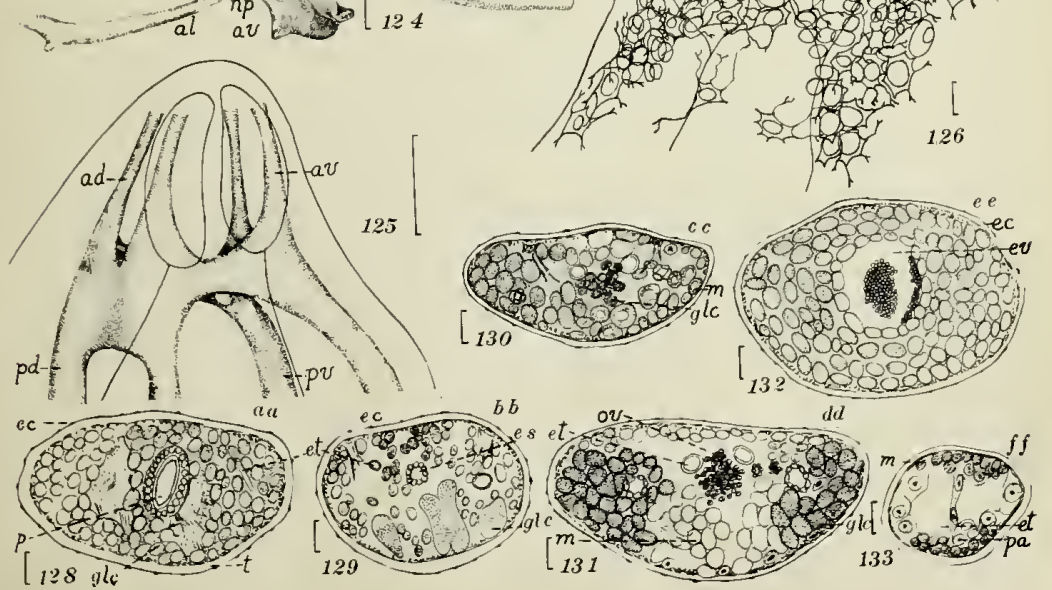


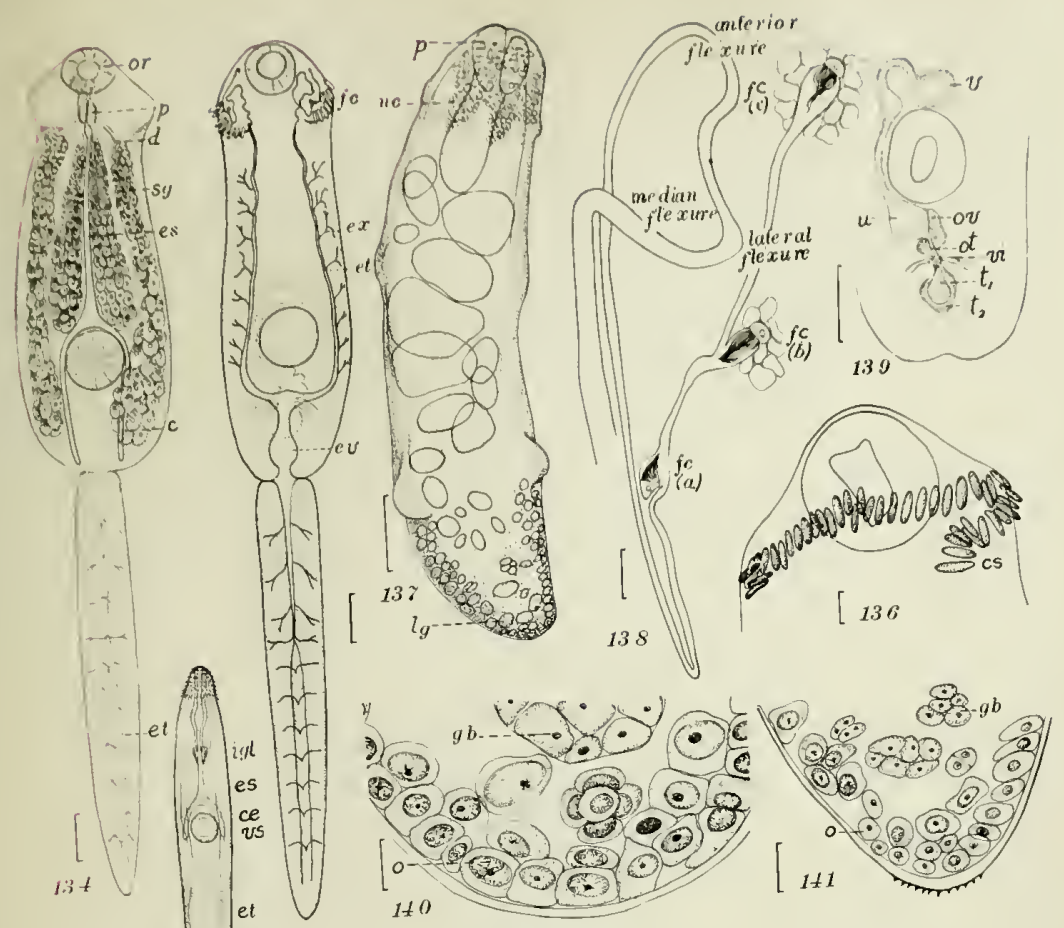

${ }_{113}{ }^{2 c y}{ }^{135}$

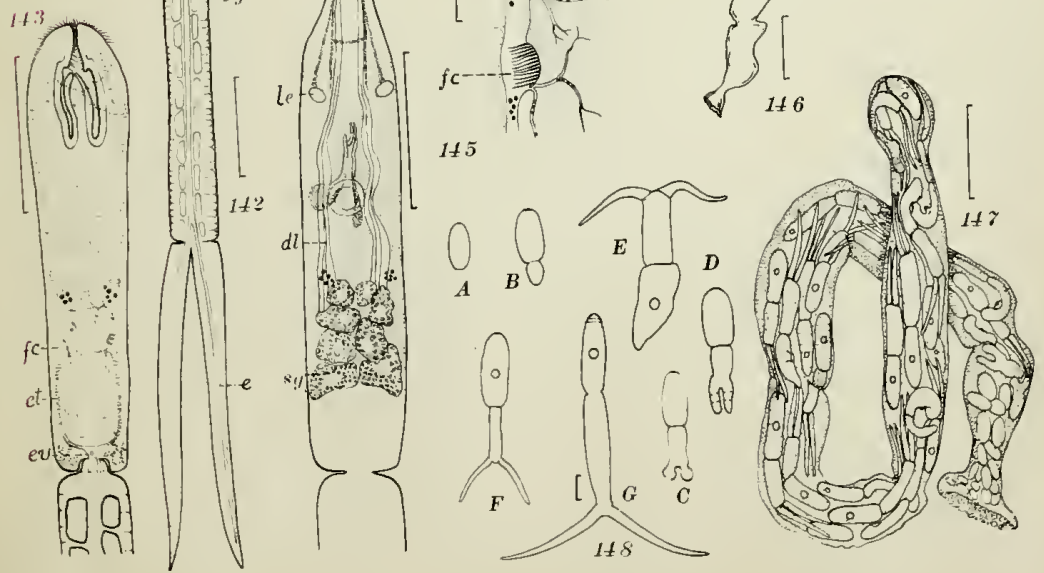




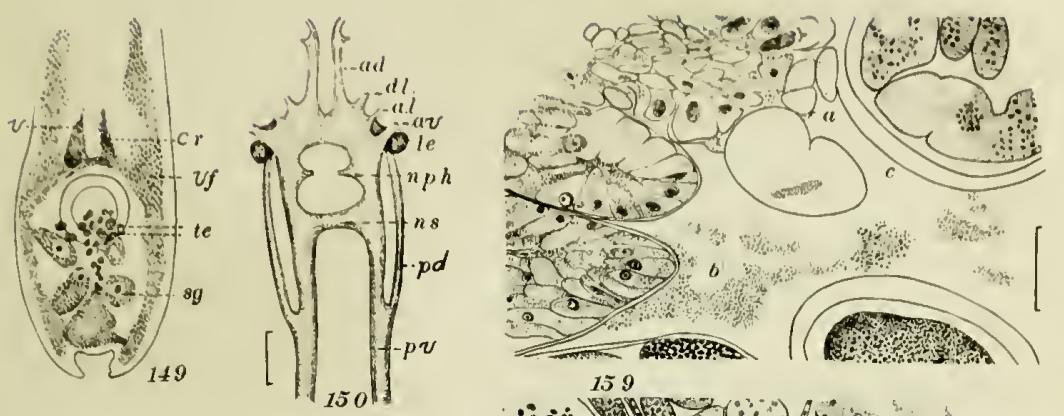

$\therefore(\because 2) d x$
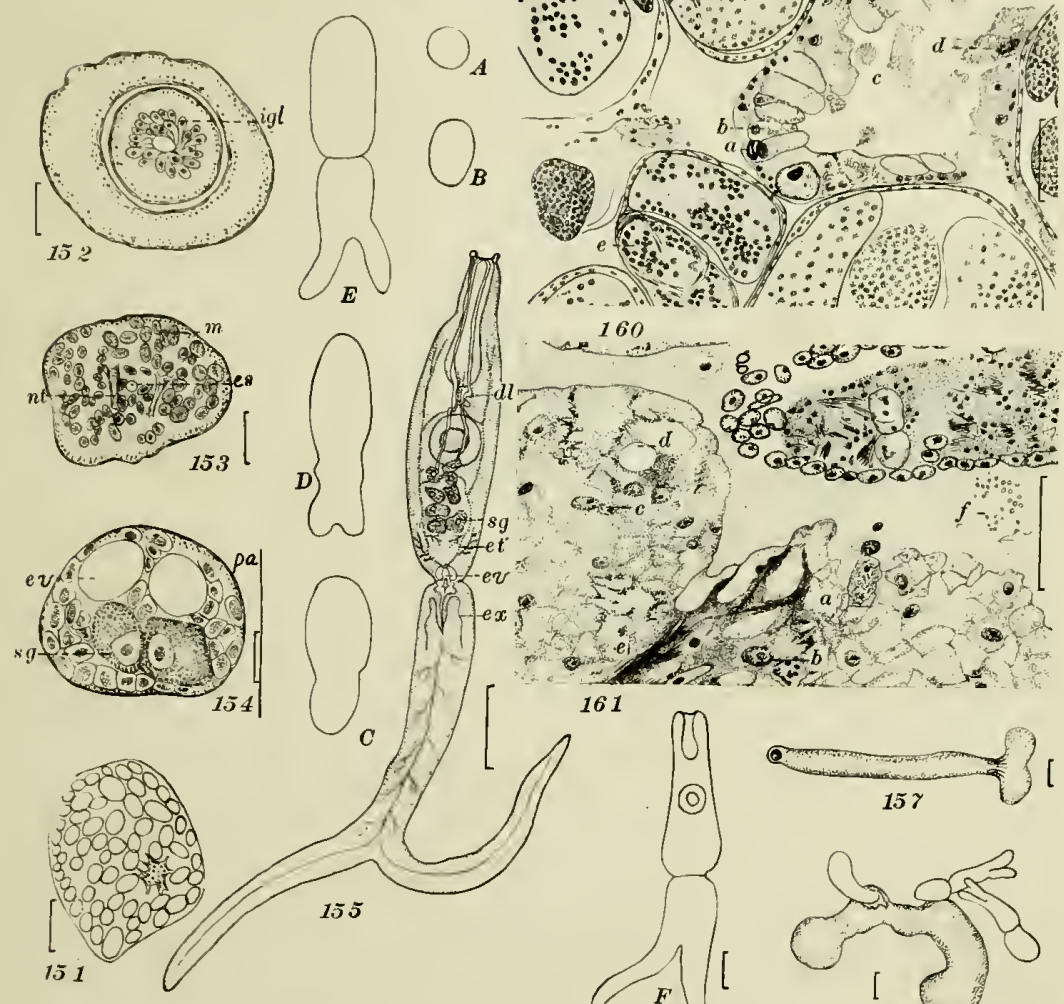

$160-g_{0} 060$

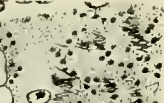

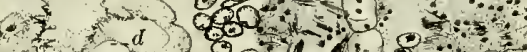

$7 x$

$6 x-6$

acis

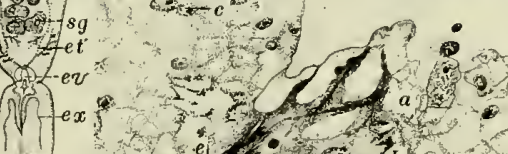

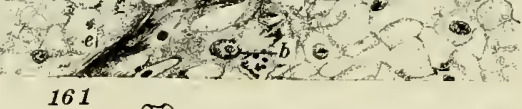

161

0

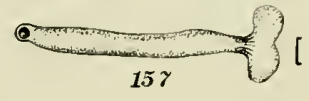

155
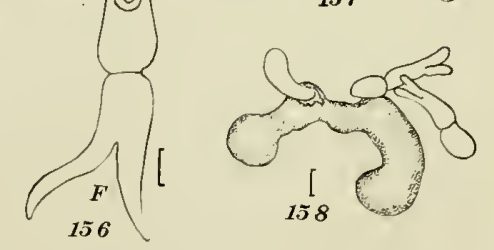

Ernest Carroll Faust was born in Carthuge \#issouri, doptenber 7. 1890. He attended the public schools of that place, irakuting frox the high school in 1907 . He attended Doerlin College from 1909 to 1912 , at the end of which time he receivel the degree of A.B. The degree of $A$. A. was conferred cn him by the Lniversity of IIlinois in 1914. He has cone Eraduate Work in the University of Michigan (ISIZ), the University of Siontana (1915-1916), the University of Chicago (1916) and the Marine Biological Laboratory at Vools Nole Wass (1913), in adaition to work in the University of IlIinois.

Frore 1907 to 1909 he taught in a private acalemy at Fairview rissouri. In 191 i he held an assistartship in Botany in Oberlin College. During the years 1912-1913 ais 1913-1914 he was research assistant to Professor Henry B. Ward at the University cf Illinois. From 1914 to 1916 he vas instructor in biolcgy in the County High School at ilissoula ilontana. During the year ISI3-1917 he was fellow in zoolory in the University of Illinois.

Io ras alected to Din Beta Kanna at Dorin College in 1912, Sigma Xi at the University of IIlinois in 2913, and Kapca Delta P1 at the University of Illinois in I8I4. the following publications have been written by in. Faust either as author or coauthor:

1913. Size Dimorphism in Adult Srermatozoa of Anasa tristis. 101. Bull, 25: 287-303.

1915. Size Dimorphism in the scrmatozoa from single Testes. (Faust and Professor Charles Zeleny). Jour. Exp. Zool., 18: $187-240$. 

Vita (continued)

1915. Dimorphism in Size of Spermatozoa knd 1ts Belaticn to the Chronosomes. (Faust, and Frofessor Charles Eeleny). proc, Nat. Acad. Sc1, ,1:91-94.

1916. Experimental jethods 1n Teaching Biology in Secondary Schools. School and Soclety, 4: 694-39:.

1917. Notes on the Cercariae of the Bitter Root VaIley, contana. Jour. Parasit.,3:105-123 


